\title{
Iwi exhibitions at Te Papa: a Ngāi Tahu perspective
}

\section{Ana Sciascia}

2012

A dissertation submitted to Victoria University of Wellington in partial fulfilment of the requirements for the Masters of Museum \& Heritage Studies degree. 


$$
\begin{gathered}
\text { Tahupotiki }=\text { Hemo } \\
\text { Ira a Tahu }=\text { Huiarei } \\
\text { Rakatehurumanu = Matiheraki } \\
\text { Tahumuri }=\text { Marutai } \\
\text { Rakawahakura = Irakehu } \\
\text { Rakaiwhakaata }=\text { Manawatakitu } \\
\text { Tuhaitara }=\text { Marukore } \\
\text { Tamaraeroa = Te Raahuanui } \\
\text { Te Aohikuraki }=\text { Rakaitekura } \\
\text { Tuahuriri }=\text { Hinetewai } \\
\text { Turakautahi }=\text { Hinekakai } \\
\text { Kaweriri }=\text { Ritoka } \\
\text { Te Reherakau = Tatua } \\
\text { Mohene = Hinenuitekawa } \\
\text { Tihope }=\text { Te Haaki }
\end{gathered}
$$

Makere Te Whanawhana = Te Oweka

Huikau = Captain William John Stirling

John William Stirling = Elizabeth Petihaukino Davis

William John Stirling = Jeanette Watson

Eliza Leader Stirling = Harold Taylor

Maymorn Allison Taylor $=$ Frank La Basse Sciascia

Piri John Sciascia = Gaylene Ann Wilson

Ana Torouka Sciascia

\section{Aoraki Matatu - Tihei Tahupotiki!}




\section{Adknowledgements}

Ka whakatau ake ki te mauka te tū mai rā-Aoraki e. Nāu ra te karaka aroha, nāu anō te mana. Kei aku whanauka o kā iwi o Kāi Tahu whānui, tera te hōrirerire te mātohu ake, he rau hou, he tipuka, he pakuati.

This dissertation would not have been possible without the support of my supervisors, Dr. Conal McCarthy and Arapata Hakiwai. Thank you immensely for your belief, patience and guidance. If I were a carver and this dissertation an artwork of whakairo, then your invaluable advice and editing would be like sand paper; smoothing over the wood to make it more appeasing to the eye, increasing the aesthetics and quality of the work. He mihi nui ki korua.

Thank you to all the participants of the research, in both the survey and interviews - your honesty and insight have enriched this research. I would particularly like to thank Poua Kukupa Tirikatene, Taua Jane Davis, Mark Solomon, my father Piri Sciascia, Megan Tamati-Quennell, Vicki Ratana, Puamiria Parata-Goodall and Carolyn Roberts-Thompson for your time and agreeing to be interviewed; your contributions have given integrity to this study.

I would also like to acknowledge the support of my husband Dylan and my incredible whanau who have supported me in myriad of ways: ehara taku toa i te toa takitahi, engari taku toa he toa takitini. In particular I would like to thank my parents, Piri and Gaylene Sciascia who have raised me with the sense of security in having a positive cultural identity.

Finally, I dedicate this dissertation to my children; Mia Niwareka, Taoka Jemal Kaweriri, Trani Amokura, Maia Kahukura Dylan - you were my biggest distraction in completing this dissertation, but you were my biggest inspiration. 


\begin{abstract}
The post-modern museum has in recent years been grappling with how best to engage with source communities in their professional practice. However there is a gap in the international literature in documenting the relationships between museums and indigenous people, particularly studies by native peoples themselves. The complex dynamics of this relationship are profiled in the following dissertation which examines the Iwi Exhibition Programme at the National Museum of New Zealand, Te Papa Tongarewa. Using the Ngāi Tahu Whānui iwi exhibition Mō Tātou as a case study, the research explores how current museum practice through collaborative exhibitions can play a role in the resurgence of iwi identity and tribal efforts to define their cultural heritage.
\end{abstract}

By combining both qualitative and quantitative methodologies endorsed by a kaupapa Māori research framework, the research design employs an online survey to gauge responses from the Ngāi Tahu iwi members to the Mō Tãtou exhibition. Findings from the survey show that $90 \%$ of respondents visited $M \bar{o}$ Tâtou, while 83\% of respondents reported that the exhibition generated new cultural aspirations. The principal motivation to visit Mō Tātou was "to learn and reconnect" to their Ngāi Tahutanga. Interviews with key informants involved in the development, both within the museum and amongst iwi, reveal the complexity of establishing and maintaining relationships. Inductive analysis produced data that threw light on some of the operational challenges that are faced during exhibition development. Finally, attention to the agency of display shows the production of meaning and the construction of a Ngāi Tahu identity by visitors and developers.

The most significant contribution of this dissertation is in providing rich data to profile a Ngāi Tahu perspective in evaluating their own tribal exhibition. In contrast to much critical theory, this study illustrates the potential of collaborative exhibitions: That partnerships and collaborations are feasible, and the results can be mutually beneficial. Te Papa continues to be a leader in their engagement with source communities, although the research makes several recommendations to further advance this process. Meanwhile Ngāi Tahu themselves have demonstrated how iwi can engage with museums to advance their cultural aspirations and exercise their tino rangatiratanga within a bicultural institution. 
Whakapapa $\quad$ i

Acknowledgements

Abstract

$\begin{array}{ll}\text { Introduction } & \mathbf{1}\end{array}$

Literature Review 3

$\begin{array}{ll}\text { Research Design } & 8\end{array}$

$\begin{array}{ll}\text { Chapter 1: } & 14\end{array}$

Museums and Māori $\quad 14$

The Museum of New Zealand Te Papa Tongarewa 16

$\begin{array}{ll}\text { Ngäi Tahu } & 20\end{array}$

Mō Tātou: The Ngāi Tahu Whānui exhibition $\quad 22$

$\begin{array}{ll}\text { Summary } & 26\end{array}$

Chapter 2: $\quad 27$

Survey Findings $\quad 27$

Analysis $\quad 36$

$\begin{array}{ll}\text { Summary } & 37\end{array}$

Chapter 3:

Ngā Kawai o te Kete: Partnership 39

Tikanga Māori: Customary Cultural Practice $\quad 48$

Ngāi Tahutanga: Culture and Identity

Summary 62

$\begin{array}{ll}\text { Conclusion } & 64\end{array}$

$\begin{array}{ll}\text { Appendices } & 70\end{array}$

$\begin{array}{lr}\text { Glossary } & 90\end{array}$

$\begin{array}{ll}\text { Bibliography } & 92\end{array}$ 


\section{Introduction}

The problematic relationship between museums and indigenous communities could be likened to that of partner dancing, like the Argentine tango. The museum assumes it takes the role of the Lead and indigenous communities the role of the Follow. In dance, the Lead is largely responsible for initiating movement, whereas the Follow's role is to maintain this movement. The most difficult thing to master in partner dancing is not the steps, but the interaction with your partner. This metaphor could also be applied to museums; it is not the steps (in other words, museum practice) that is the biggest challenge but the interaction with indigenous communities. However, the lead can change. In partner-dancing, this is called 'hijacking' where the Follow steals the lead and they reverse roles for some time (Raper 1998). This research considers a comparable shift in the power relationship between museums and indigenous communities in which the former modernist authority of the museum has been challenged by the emerging voices of indigenous communities (Hooper-Greenhill 2004). By offering a tribal Māori perspective on a collaborative museum exhibition in New Zealand, it addresses a gap in the international literature on museums and source communities which lacks work about and by indigenous people themselves (Peers and Brown 2003).

This dissertation explores the evolving relationship between museums and Māori by examining current exhibition practice at the Museum of New Zealand Te Papa Tongarewa (Te Papa). Through a case study of the Ngāi Tahu Whānui iwi exhibition Mō Tâtou, this study critically analyses the ways in which policy is put into practice and how iwi exhibitions play an active role in the resurgence of iwi identity. It aims to investigate whether the Iwi Exhibition Programme (IEP) at Te Papa is successful in giving iwi (tribe, tribes) a voice within the museum's structure. Another objective is to assess to what extent iwi are able to express their kaitiakitanga (guardianship) and tino rangatiratanga (self-determination) through the IEP. The research questions considered in this dissertation ask: how does Te Papa manage and develop a relationship with iwi through iwi exhibitions and how have Ngāi Tahu used the iwi exhibition to enhance their tribal identity and advance their cultural heritage aspirations? 
The IEP is the most visible demonstration of tribal participation and partnership at Te Papa. It has been operating for just over ten years, with the Ngāi Tahu Whānui exhibition Mō Tātou being the fifth to be held since the national museum reopened in 1998. It is now timely to examine and reflect on the process of developing iwi exhibitions and to consider whether they are fulfilling what was envisaged for both iwi and the museum. The IEP is based on a reciprocal relationship between Te Papa and iwi (Te Papa website 2011). It is therefore important to understand not only how the IEP is contributing to the museum's strategic direction, but also to learn more about tribal aspirations for their taonga (treasures) and cultural heritage.

My interest in this topic has emerged from my personal views of the significance of taonga and kaitiakitanga for Māori. My own tribal affiliations include Ngāi Tahu, descending from my grandmother who is from the Stirling family of Riverton and Ruapuke, Southland. As a first-year Masters student of Museum and Heritage Studies at Victoria University, I vividly remember learning about the political nature of display, the power relationships involved in exhibiting cultures in a museum and the process of constructing meaning. Up until this time, I had unknowingly accepted the authoritative role of the modernist museum, and the transmission model of communication which Hooper-Greenhill describes as "a linear process of informationtransfer from an authoritative source to an uninformed receiver" (cited in Carbonell 2004, 560). I was almost childlike in thinking: if that's what the museum said, then it must be true! While somewhat taken aback at my naivety, I immediately started to look at the museum display of Māori material culture with a new analytical perspective. At the same time the Ngāi Tahu Whānui exhibition Mō Tãtou was about to open at Te Papa in Wellington, and I focused my newfound analysis on the iwi exhibition; both its formation and production. I was also fortunate enough to carry out my work placement for the MHST 512 paper at Te Papa and work alongside Māori collection managers and other staff with the installation and opening of the Mō Tätou exhibition in 2006. Having worked on the exhibition at Te Papa and visited the later versions in South Island museums, in this study I wanted to examine in more depth what the members of the Ngāi Tahu tribe thought of the experience. This introduction sets out the framework for this research. First, I present in the following literature review the theoretical parameters, and then I explain the methodology for the study, before giving an outline of the chapters. 


\section{Literature review}

In museum studies and related fields, there has been a great deal of writing about museums, exhibitions and 'Other' peoples. A lot of the literature describes how the voice and narrative of indigenous peoples in post-settler states are expressed in museum displays (Hendry 2005, Lidchi 1997). Scholars argue that the prime responsibility of the Modern museum was its encyclopaedic and complete collections (Hooper-Greenhill 2004, Corsane 2004). Moira Simpson describes the movement of information and artefacts as "largely one way, from source to collector to museum - there to be displayed and interpreted regardless of the views or sensitivities of the original owners" (1996, 242). This body of literature provides an academic setting for this research by presenting a global perspective on the dynamic relationship between museums and indigenous communities. My study will provide a detailed case study of Aotearoa New Zealand which may be compared with comparable situations in countries such as Australia and Canada.

The interdisciplinary nature of museum and heritage studies broadens the discourse surrounding museum and indigenous communities, and utilises a range of theories from related fields to help explain the inevitable changes which occur in museum practice (Witcomb 2003). This study focuses on three particular inter-related theories to provide an analytical framework for the research on Mō Tätou. These theories are: source community (Peers and Brown 2003), the politics of display (Karp and Lavine 1991, Lidchi 1997, Simpson 1996, Hooper-Greenhill 2004), and cultural identity (Hall 1997, McDonald 1998).

First, Laura Peers and Alison Brown make a useful contribution to my analytical framework by acknowledging the position of the indigenous community in regard to the objects in the museum collection. They state that one of the most important developments in the history of museums is the "dramatic change in the nature of relationships between museums and their source communities" $(2003,1)$. Museums are no longer the "sole voices of authority in displaying and interpreting those objects," Peers and Brown argue, "but acknowledge a moral and ethical (and sometimes political) obligation to involve source communities in decisions affecting their material heritage" (2003, 2). Conal McCarthy explains that source communities are not only the historical group from whom an object originated, but also represent the present-day relationship as the "living descendants today who are often the audiences for exhibitions of these very same objects" $(2011,5)$. The work of Peers and Brown examines the actual relationships forged 
between museums and source communities through museum objects which act as links between them, and the attendant change in attitudes these links bring about within the museum profession; perhaps more constructive for this study of taonga and iwi is the analysis of the potential of the museum object to mediate relations between museums and source communities. This concept is supported by James Clifford's theory of museums as 'contact zones’. According to Clifford, "when museums are seen as contact zones, their organizing structure as a collection becomes an ongoing historical, political, moral relationship - a power-charged set of exchanges, of push and pull" (1997, 192). For the purpose of this study, Clifford's concept reminds us of the role of the object or the agency of taonga as a catalyst for new or renewed relationships.

In articulating the notion of 'source communities', Peers and Brown provide a case study where curator Margaret Hanna writes "candidly" about the redisplay of the First Nations gallery in the early 1990s at the Royal Saskatchewan Museum in Canada. Hanna describes the "patience and persistence" needed to overcome deeply entrenched attitudes by some staff, who were committed to the "traditional view of the museum world", whereby the curators were the experts and "asking the spiritual leaders was a nice formality, but we didn’t really have to follow their advice if it didn’t fit in with our plans" (2003, 44). Peers and Brown suggest that source communities seek a "true partnership rather than superficial involvement" with museums, which usually only supports the conventions of museological practice within the institution $(2003,2)$. This insight is particularly meaningful for this study, as the IEP at Te Papa attempts to establish partnerships that are "active and alive" between iwi and the museum (Te Papa n.d., 1). The still-emerging nature of the work between museums and source communities means that much is yet unpublished, and Peers and Brown are frank in calling for further research. "...more publications, which both reflect and explain the new ways of thinking about and working with collections," they argue, "are needed by museums as a starting point to begin developing relationships with source communities" (Peers and Brown 2003, 12). This dissertation aims to fill this gap and contribute to this literature by documenting the partnership between iwi and Te Papa - with particular reference to Ngāi Tahu Whānui - and to investigate the many issues encountered in the process of developing the exhibition Mō Tātou. Furthermore, Peers and Brown note that the greatest difficulty in selecting articles for their publication was the "lack of material written by the source community members themselves" $(2003,13)$. This research responds directly to this need by profiling the perspectives of the source community, namely 
members of the Ngāi Tahu tribe. Of particular significance in this study is not only the relationship between museum and source communities, in terms of the learning and growth for the national museum and its professionals, but also the benefits within the source communities themselves. This research seeks to go further in asking how Ngāi Tahu has used the exhibition process to advance their tribal agenda.

The second body of literature relevant to this study is the work on the politics of display. I found that Henrietta Lidchi's idea of the "poetics and the politics of exhibiting other cultures" provided analytical tools to examine the construction of meaning through the display of cultural objects and the museum's relationship to knowledge and power. In examining museum display, Lidchi suggests that ethnographic museums are revealing because they "have had to address themselves in a concerted fashion to the problems of representation" $(1997,153)$. Ethnographic discourse, Lidchi argues, does not reflect the "real state of cultures it exhibited so much as the power relationship" $(1997,161)$. Thus the politics of knowledge inscribes an unequal power relationship into the poetic form of the display. Lidchi clearly shows how the museum becomes an arbiter of meaning "since its institutional position allows it to articulate and reinforce the scientific credibility of frameworks of knowledge or discursive formations through its methods of display" $(1997,198)$. The question of institutional power, Lidchi states, is a critical factor when assessing museum practice, not only in the internal processes of exhibiting but externally in relation to the broader social role of the museum within society and its relationship to knowledge. Lidchi explains that once museums start to acknowledge that collecting and exhibiting are political activities, ethnographic objects will be "increasingly defined and represented by the original peoples or their descendants in an auto-ethnographic process" (1997, 204). This is echoed by a strategy released by Museums Aotearoa for the museum sector in New Zealand, which included recommendations that Māori should determine how their taonga should be presented and interpreted and that the mana of the taonga reside with the iwi from which it originates $(2005,20)$.

The poetics of exhibiting is defined by Lidchi as the "practice of producing meaning through the internal ordering and conjugation of the separate but related components of an exhibition" (1997, 167). This demonstrates the layers and complexities of exhibiting through various display facets including collecting, labelling, language, reconstruction, simulacra and use of photography. 
Lidchi explains that the meaning of objects is "neither natural nor fixed: it is culturally constructed and changes from one historical context to another depending on what system of classification is used" $(1997,166)$. The politics of exhibiting is described as "the role of exhibiting museums in the production of social knowledge" $(1997,185)$. This discursive approach goes beyond the production of display to the politics of knowledge - that is, the museum's relationship between knowledge and power. Ivan Karp argues that the most powerful agent in the production of exhibiting cultures is not the audience or the object but the "exhibition makers" (Karp and Lavine 1991, 15).

Although this critical theory of the poetics and politics of exhibiting culture is vital for this study, dialogue theorists (Bohm 1991, Buber 1998, Isaacs 1999) offer further insights by developing an operational theory explaining how the power-knowledge relationship between museums and indigenous communities could be addressed. Isaacs describes dialogue as a discipline of "collective thinking and inquiry" which holds the potential for "allowing entirely new kinds of collective intelligence to appear" (1993, 39). Bohm writes that while "authority and hierarchy permeate our societies, dialogue can only take place when we can suspend those notions of authority" (Dialogue digest website 2011). Participants in dialogue must also "suspend assumptions", Bohm continues, because "we seem to have a strong need to defend our assumptions" and this only prevents true dialogue (Dialogue digest website 2011). The inclusion of dialogue theory adds depth to the analytical framework for this research in examining the relationship between museums and Māori communities. It also provides a means to explore how the power-knowledge relationship occurs; that is to say, it offers a way of describing what it looks like within the museum and how it works operationally. The function of a museum as a communicator cannot be separated from cultural issues of knowledge, power, identity and language (Hooper-Greenhill cited in Carbonell 2004, 572).

Lastly, this study draws on theories of identity formation in cultural studies which have been applied liberally to museums. Much of this literature examines the ways in which unequal relations between Europeans and colonised peoples have been played out in museums through representation of 'Self' and 'Other' (Nederveen-Pieterse in Corsane2005). However, in my view the complex relationships between museums and Māori within Aotearoa New Zealand have moved beyond much of this discourse which posits a sharp and one-sided dichotomy between the west and the rest. I have drawn on the work of Stuart Hall (1997) 
who sets up two different propositions about cultural identity; both provide a wider academic context for this dissertation. First, Hall refers to people with a "shared history and ancestry in common". He continues by stating "within the terms of this definition, our cultural identities reflect the common historical experiences and shared cultural codes which provide us, as 'one people', with stable, unchanging and continuous frames of reference and meaning" (1997, 223). This perspective can easily be transferred to the Māori world view of whakapapa (genealogy) which is the fundamental fabric of Māori identity. Whakapapa is a fixed, continuous matrix of identity which is the very essence of being Māori. Secondly, Hall describes cultural identity as "a matter of becoming as well as of being. It belongs to the future as much as to the past". He continues by saying, "but like everything which is historical, they undergo constant transformation. Far from being eternally fixed in some essentialised past, they are subject to the continuous 'play' of history, culture and power" (Hall 2003, 225). This position demands consideration when assessing how Mō Tâtou played a role in the production of iwi identity for Ngāi Tahu. As Hall puts it, identity is not "grounded in the archaeology, but in the re-telling of the past" (2003, 224).

A 1994 newspaper article once referred to Ngāi Tahu as the 'White tribe'. It reported the analysis of Professor John Gould, a first generation migrant from Bristol, England, who constructed a rating system of 'Māoriness' from 16 tribes. He concluded that Ngāi Tahu were the "least Māori" (O’Regan 2001, 14). It is envisaged that Mō Tātou will play a significant role in the reemergence of a strong cultural identity for the Ngāi Tahu people. Tribal leader Tahu Potiki has described this identity formation as putting up "those cultural icons, the cultural messages to our young people - This is what Ngāi Tahu looks like and sounds like!" (cited in O’Regan 2001,167). Māori notions of display are often wrapped up in concepts of mana (power, authority, status), advancement, presenting a living culture and contributing to a strong cultural identity (Mead 1984, McCarthy 2007). As McCarthy explains, "display does not merely reflect the world, but actively constructs it" $(2004,5)$. This dissertation will explore how, in the same way, the iwi exhibition not only reflected cultural identity for Ngāi Tahu but also simultaneously constructed it. This allows me to examine events associated with the Mō Tâtou exhibition that enabled new shared experiences for the iwi, such as the opening and closing ceremonies of the exhibition. Māori scholar Mason 1(1998, 2002) argues that identifying with a particular culture helps people feel they belong and gives them a sense of security. It provides access to 
social networks which provide support and shared values and aspirations. An established cultural identity has also "been linked with positive outcomes in areas such as health and education" (Durie 2001, 87).

In summary, this survey of the literature has allowed me to pull together theories from Peers and Brown, Lidchi and Hall which provides an analytical framework for this dissertation, and situates the research within the broad multi-disciplinary context of museum studies. These theories - source community, the poetics and politics of exhibiting and identity formation - will be applied to the relationship between Māori and museums that is at the heart of this research. Other concepts such as dialogue, partnership and effective exchange provide a contested yet positive model for examining the production of cultural identity and the power-knowledge relationship of exhibiting the cultures of source communities. This framework will enable me to conduct research on current museum practice in Aotearoa New Zealand. Furthermore, including an indigenous perspective on museums and indigenous responses to exhibiting will address the gap in the literature and contribute to the developing research in this field. Before moving on to provide an outline of the contents of this dissertation, I turn now to a brief outline of the research design which explains how the research was carried out.

\section{Researchdesign}

As the majority of my research topic is associated with taonga Māori and involves a Māori world view, my research is heavily influenced by a kaupapa Māori research methodology and perspective. Ethics in research within a kaupapa Māori perspective is grounded within tikanga Māori (Māori customs and practices) and encourages "Māori to remain as Māori through all phases of the research process" (Rangahau website 2011). It acknowledges that intrinsic connection between the researcher, the researched and research.

When addressing reflexivity in kaupapa Māori research, I am aware that not only am I a postgraduate student of Victoria University, but I am a descendant of Ngāi Tahu. For Māori, it is important to not only identify who I am, but also my whakapapa and to whom I belong. Kaupapa Māori as an anti-positivist methodology acknowledges that biases exist and requires the researcher to use their cultural knowledge in the analysis phase. This means that kaupapa Māori 
methodology requires the researcher to acknowledge the validity of Māori knowledge and incorporate this knowledge and a Māori world view in the interpretation and analysis of research data (Walker, Eketone and Gibbs 2006). I have also used a kaupapa Māori perspective in the data-collection process by taking into account tikanga Māori, such as whaikōrero (oratory) on the marae (ceremonial courtyard).

The research objectives are proposed tools to address how the research aim will be approached and provide a measure to guide analysis. The five objectives are:

1. To examine Te Papa's bicultural policies, and evaluate the IEP and Iwi Relationships strategy.

2. To explore notions of partnership between iwi and Te Papa - with particular reference to Ngāi Tahu Whānui.

3. To investigate the processes and issues encountered in the development of the Ngāi Tahu Whānui iwi exhibition Mō Tātou.

4. To investigate how Mō Tâtou plays a role in the construction of iwi identity for Ngāi Tahu.

5. To investigate how Ngāi Tahu have utilised the IEP at Te Papa to advance their efforts to revive their tribal cultural identity.

This dissertation uses a survey and interviews as its main research methods. This provides both qualitative and quantitative data in exploring the research question: how does Te Papa manage and develop a relationship with iwi through the IEP process and how have Ngāi Tahu used the iwi exhibition to enhance their tribal identity and advance their cultural heritage aspirations?

The survey was conducted online to generate a large sample and get a good response rate of iwi members given the geographical vastness of Ngāi Tahu's tribal boundary which includes the majority of the South Island. This immediately brings up issues concerning those who are unable to participate or do not have access to the internet. However, I believed this method gave a wider opportunity for people to participate and provided a large enough catchment for the purposes of this dissertation. Online media is also effectively used by Te Rūnanga o Ngāi Tahu (Te Rūnanga) (the tribe’s governing body) to regularly communicate with iwi members. The Survey Monkey software was used to format and host the online survey. Questions were developed to investigate 
quantitative data about the members of Ngāi Tahu Whānui and their response to the Mō Tātou exhibition. Comment boxes throughout the survey also provided an opportunity for iwi members to use their own voice to express their response to the exhibition. This also provided a multi-vocal quality to the survey by producing qualitative data (see appendix 15 for the full text and layout of the survey). The online survey was promoted among whānau (family) in the Ngāi Tahu tribe by Ngāi Tahu Communications who put a link to the survey on the front page of Te Rūnanga's website. A link to the survey was also posted on their Facebook page and on Twitter. The duration of the survey was two weeks, which was considered sufficient time to allow iwi members who were likely to respond and complete the online survey to do so. A Facebook post and reminder email was also sent three days before the survey closed.

For the interviews, I used an unstructured interviewing technique whereby a number of openended questions were used to make interviews fluid and flexible (Sarantakos 2005). This research method allows people's perceptions to come out and enables concepts and relevant issues to be defined in the interviewee's own terms. In one instance, an interviewee had asked for questions to be forwarded before the interview, so that they could give it some prior thought and I assume be most helpful to their contribution. However, I explained that, further to the initial information that was sent which introduced the research topic and outlined the key themes in the research question, that I was more interested in having a kōrero (in other words a more conversational type of interview), where, apart from my primary open-ended questions, supplementary questions would flow naturally from the conversation (see appendix 15 for full list of interview questions).

Either an established relationship with most of the interviewees or their knowledge of my whānau and whakapapa enabled a good rapport and an atmosphere of trust. Walker (2006) suggests that a Māori world view is an important principle of kaupapa Māori research; and that whakawhanaungatanga (the process of identifying, maintaining or forming past, present and future relationships) is one of the more important concepts whereby Māori are enabled "to locate themselves with those present; the identification of these relationships then allows for in-depth information to be shared" (Walsh-Tapiata in Walker, Eketone and Gibbs 2006). I was also mindful that these relationships will extend beyond the dissertation research. This required careful consideration of sensitive issues that may have arisen, while not compromising the 
research, to present the findings in a balanced manner. Consideration of confidentiality and anonymity was also given to sensitive issues that arose. However, this was deemed unnecessary. Thankfully, interviewees were happy to be interviewed and forthcoming in their opinions. I saw this as their commitment and support to the project; whether it was to Ngāi Tahu, Te Papa, the Mō Tàtou exhibition, my research - or all four.

Six of the eight interviews occurred at the time of the final closing of the Mó Tâtou exhibition, 17 April 2011 at the Otago Museum, Dunedin. I was fortunate that this event brought together important people who had contributed to the development of the exhibition including members of the Iwi Steering Group (ISG). They were naturally preoccupied with the exhibition at that time but nevertheless readily reflected on their time working on the exhibition and considering its significance. This led to successful and engaging interviews and very well-articulated interviewees. For me, it was also an important part of the research being able to sit in the exhibition on its final day with kaumātua (elders, leaders) and listen as they shared their thoughts and opinions. Interviews conducted in Dunedin were with the following people.

- Kukupa Tirikatene (Ngāi Tūāhuriri me Ngāti Irakehu o Ngāi Tahu; Ngāti Pahauwera; Ngāti Kahungunu): Ngāi Tahu kaumātua who was in residence at Te Papa for the two years while the exhibition was at Te Papa.

- Jane Davis (Ngāti Ruahikihiki me Ngāti Atawhuia o Ngāi Tahu; Kāti Mamoe; Waitaha): ISG member and currently the Chairperson of the Ngāi Tahu Fund.

- Piri Sciascia (Ngāti Kaweriri me Ngāi Te Ruahikihiki o Ngāi Tahu; Kāti Mamoe; Ngāti Kahungunu; Ngāti Raukawa): Deputy Chairperson of the ISG, current member of the Ngāi Tahu Fund.

- Mark Solomon (Ngāti Kurī, Ngāti Irakehu, Ngāti Ruahikihiki me Ngāi Tūāhuriri o Ngāi Tahu; Ngā Rauru Kii Tahi; Ngāti Pahauwera; Ngāti Kahungunu ki Wairoa): Kaiwhakahaere (Chair) of Te Rūnanga o Ngāi Tahu, a position he has held since 1998. He was also a representative on the Te Papa Board from 2001 to 2007.

- Vicki Ratana, (Ngāti Irakehu me Ngāi Tūāhuriri o Ngāi Tahu; Ngāti Waewae; Te Rarawa): Project Manager for Mō Tātou, previously Communications Manager at Te Rūnanga o Ngāi Tahu. 
- Puamiria Parata-Goodall (Ngāti Ruahikihiki, Ngāti Irakehu, Kāti Huirapa me Ngāi Tūāhuriri o Ngāi Tahu; Ngāti Māmoe; Ngāti Kahungunu): Previously worked at the Canterbury Museum, currently employed as Events Manager at Te Rūnanga o Ngāi Tahu.

The remaining two interviews were with Te Papa staff who were interviewed in Wellington on 9 May 2011.

- Megan Tamati-Quennell (Ngāi Te Ruahikihiki me Ngāti Moki, Ngāi Tahu; Te Atiawa): curator of the Mō Tātou exhibition and current Curator Contemporary Māori and Indigenous Art at Te Papa.

- Carolyn Roberts-Thompson (Te Aupouri): Team Manager of the Iwi Relations Team at Te Papa. Currently seconded to the Visions Strategic Team at Te Papa.

There is a wide range of literature (Krueger 2000, Pope 2000, Gibbs 2008, Thomas 2003) that documents the underlying assumptions and procedures associated with analysing qualitative data. The primary purpose of the inductive approach is to "allow research findings to emerge from the frequent, dominant or significant themes inherent in raw data, without the restraints imposed by structured methodologies" (Thomas 2003, 2). I adopted an inductive approach to data analysis, whereby data was not grouped into predetermined themes. Rather, I assessed responses from the interviews in terms of frequency and intensity of what was said and themes that emerged from within the interview; this is often referred to as 'coding'. As Thomas explains, "inductive coding begins with close readings of text and consideration of the multiple meanings that are inherent in the text" $(2003,4)$. Although my data analysis is primarily derived directly from the inductive analysis of the interviews, I did also consider the research objectives to see whether the themes that were emerging from the interviews were fulfilling my original research intention or whether new data was being produced that I had not considered when determining the research question and objectives.

In concluding this introduction, I want to provide an outline of the contents of this dissertation. The dissertation is divided into three chapters and a conclusion. The first chapter provides further background information about Māori and museums, Te Papa, Ngāi Tahu and the Mō Tātou exhibition; this helps provide a fuller understanding of the context within which the research 
topic is situated. The second chapter then presents the quantitative data gathered from the Ngāi Tahu iwi online survey. These findings and analysis consider the response of tribal members to the exhibition at various venues. Chapter three examines the qualitative data, consisting of eight interviews with key informants associated with the exhibition at Te Papa or within the tribe. In the ensuing analysis, three central themes emerge, namely ngā kawai o te kete (partnership), tikanga Māori (customary cultural practice) and Ngāi Tahutanga (identity). Finally, the conclusion will provide a brief summary of the key findings, assess the relevance of the research for museum studies, and make recommendations for partnerships between museums and Māori, and future iwi exhibitions at Te Papa. 


\section{Chapter One}

The following chapter provides background information necessary to contextualise the topic of this dissertation within a New Zealand context. First, through exploring the long-term relationship of Māori and museums, insights are gained into the complexity and contested nature of this cultural landscape up to the present time. I then explore Te Papa's bicultural commitments and introduce the concept of mana taonga before examining the Iwi Exhibition Programme (IEP). Next comes an introduction to and brief history of Ngāi Tahu. Its tribal structure is presented, followed by a descriptive analysis of the Mō Tātou exhibition and the form it took at Te Papa. This background information provides a broader context to the research topic and allows a deeper understanding of the issues examined in this study.

\section{Museums and Māori}

Within the New Zealand context, Māori have generally expressed dissatisfaction with the way museums have historically collected and interpreted their culture. Māori academic Dr Hirini Moko Mead argues that "museums were not founded to serve the needs of the Māori people, but rather to entomb us and our material culture. We were to become the prize exhibits of the nineteenth century, now safely ‘domesticated’ in museums for a predominately Pākēha audience" (Mead 1985, 16). As Moira Simpson explains, "there is no doubt that museums and anthropologists contributed greatly to the preservation of material culture" (1996, 242). However, Simpson goes on to comment that "they have also contributed to the cultural decline experienced by many indigenous people, as cultural material was avidly collected in desperate attempts to salvage as much as possible from tribal people who were deemed to be facing extinction" (1996, 242). Māori have often challenged the unlawful or unethical acquisition practices of museums. They regarded museum collections containing Māori material culture as being stored in poor conditions with no or very little concern for the mauri (life force) and spiritual care of the object or the tribal histories and values from which it came (Mead 1986, Tapsell 2005, Waitangi Tribunal 2011). Perhaps more disturbing was the display of ancestral 
Māori remains including mokamokai (preserved tattooed heads) which, as Māori academic Paul Tapsell describes, were displayed according to "mutually exclusive Western values of ownership, capture and Otherness" $(2005,153)$. Museums were described as a rua kōiwi or a death house that represented "a sad repository of plunder and grief" (Te Awekotuku cited in Gathercole and Lowethal 1994, 114).

This belief that museums were alienating and lifeless places for Māori has been seriously questioned in recent research which casts the historical relationship between Māori and museums in a new light. Museum professional and academic Conal McCarthy $(2007,2011)$ reveals a history of active Māori engagement with museums, which he suggests "complicates current orthodoxies about cultural politics and indigeneity". McCarthy provides a more complex view by examining Māori exhibits within a "culture of display", which he argues "is shaped by the complex relations of colonisation, modernity and nationhood" (2007, 7). This research counterbalances earlier literature in this field by going beyond the stereotypic image of oppressor and oppressed that has been so central to the critique of ethnographic exhibitions for many years (Peter Bjerregaard, 2006). While the scope of this dissertation does not include the conflicting perceptions of the historical relationship between Māori and museums, it is interesting however to ask why the current Māori orthodoxy is so damning of the Māori-museum relationship. This has often been considered one of appropriation and alienation, when detailed scrutiny of the related archival material has uncovered many instances of Māori involvement and ventures between Māori people and tribes and local museums (McCarthy 2007).

\section{Te Māori exhibition}

The evolving relationship between indigenous source communities and museums has occurred within a much broader historical context of social change (Hendry 2005, Simpson 1996, Shelton 2006). Concepts such as tino rangatiratanga, so central to Māori political assertions, have also set the terms of debate in struggles over ownership of indigenous culture and heritage (Durie 1998, Hill 2009, Smith 2011). The ground-breaking Te Māori exhibition in 1984-7 reflected the wider

context of vigorous Māori social advancement in the 1980s, particularly with the revitalisation of the Māori language and the establishment of the Waitangi Tribunal (Walker 1990). An internationally acclaimed exhibition, Te Māori provided a significant contribution to museum practice in Aotearoa New Zealand, not only for the National Museum in Wellington, but also for 
the many provincial museums who were involved in the loaning of taonga. The enduring legacy of Te Màori enunciated the concept of cultural ownership - the involvement of iwi in the management and interpretation of their taonga and the acknowledgement of their tribal kaitiakitanga (Mead 1984). Te Māori was also credited for bringing a new Māori audience to the museum, inspiring young Māori to the museum profession and Māori participation in the planning and development of the new national museum when it reopened in 1998 (Tamarapa 1996, Mead 1986, Te Papa 2004, Butts 2002, McCarthy 2011).

\section{The Museum of New Zealand Te Papa Tongarewa}

\section{Conceptual, legislative and organisational foundation}

The Treaty of Waitangi underpins the notion of iwi partnership within a bicultural museum. While The Museum of New Zealand Te Papa Tongarewa Act 1992 does not make particular reference to the Treaty of Waitangi, Te Papa's conceptual framework is founded on Papatūānuku (the earth on which we all live), Tangata Whenua (those who belong to the land by right of first discovery) and Tangata Tiriti (those who belong to the land by right of the Treaty of Waitangi) (Te Papa Bicultural Policy n.d.). Te Papa has also adopted six corporate principles derived from themes within Te Papa's concept; one of these corporate principles is that "Te Papa is bicultural" (Te Papa 2010, 22) (see appendix 2 for Te Papa’s full operating framework). Te Papa’s bicultural policy is founded on three key Treaty principles that define its intent and the spirit of its management and operation. These principles are partnership, protection and participation. The policy also encompasses three key Māori concepts that aid in defining the nature of relationships and interaction between tangata whenua and tangata tiriti at Te Papa; these concepts are kawanatanga (governance), rangatiratanga (self-determination) and kaitiakitanga (guardianship).

Furthermore, the museum is not only committed to bicultural partnerships when just dealing with Māori or taonga, but "in all that it does" (Te Papa 1991). Exactly where Te Papa sits in the bicultural continuum is a matter for debate, but as David Butts comments "there is no doubt that it has taken a leading and constructive role in exploring the notion of a bicultural museum" (2002, 226). More recently, the Waitangi Tribunal released a report Ko Aotearoa Tenei on the Wai 262 claim relating to New Zealand's law and policy affecting Māori culture and identity. It states "the model of indigenous participation in museum management developed by Te Papa has made 
it a world leader, and rightly so". It continues by saying Te Papa's bicultural policies have "set a benchmark that other public museums in New Zealand should aspire to" (2011, 508). Although the Tribunal commended the museum's bicultural approach and shared decision-making with Māori, it also encouraged Te Papa to "take the next step in the evolving indigenous-settler partnership approach to cultural heritage". This point is also acknowledged by Te Papa in its 2009-2010 Annual report which states "Our challenge is ongoing - to remain true to the community and relevant in an ever-changing world" (2010, 14).

The conceptual and operational approach taken by Te Papa in regard to biculturalism and Treaty partnerships has led to an increase in both participation and expectations by iwi. The Iwi Relationship Strategy was developed to ensure that these relationships are "managed in an appropriate way and within limited resources" and to identify areas to develop new relationships (Te Papa's Iwi Relationship Strategy n.d.). "If this museum is to make credible its commitment as a bicultural institution", argues senior Māori curator Awhina Tamarapa, "then tribal consultation must certainly be the foundation of cultural partnership" (1996, 167). Te Papa's ongoing partnerships with iwi are critical to the overall success of the museum in telling the nation’s stories. Arapata Hakiwai, then Director Mātauranga Māori at Te Papa, explains that "For a long time museums have been rich in collections and poor in relations, and really we need to be rich in both the collections and relationships" (Hakiwai pers. comm. 12 Sept. 2006). The focus of activity for Te Papa's future iwi relationships are in maintaining and developing relationships through the IEP and other exhibition development, its collections and the repatriation of kōiwi tangata (skeletal remains) (Te Papa 2006a).

\section{Mana Taonga}

The concept of Mana Taonga was developed through consultation with iwi and other key stakeholders before being recommended by Ngā Kaiwawao, the Māori Advisory Group to the museum's Development Board. It was endorsed by the Board in 1992 and has since become a corporate principle for the museum (McCarthy 2011). The Mana Taonga principle develops Hirini Mead's concept of "cultural ownership" by affirming the spiritual and cultural connections of the source communities to taonga, and recognising their role in enhancing the care and understanding of collections and taonga. This principle underpins the museum's guardianship of 
all taonga and collections (Te Papa 2010). The importance of Mana Taonga to Te Papa was expressed by then Chief Executive Seddon Bennington:

The recognition of the museum as a guardian rather than an uncontested owner, or even a contested owner, is very important. We could express that even more strongly to our Māori partners, but I think we have gone some way in creating this climate of trust and in some ways it's a complete shift from that 'we own it, we do the research, we're in control here’ attitude to recognising the authority of iwi (in McCarthy 2011, 115).

Furthermore the Waitangi Tribunal stated in their recent report Ko Aotearoa Tenei that:

the mana taonga policy is well regarded for its genuine effort to involve kaitiaki in decision-making over their taonga. Professor Mead argued that kaitiaki have a right to make decisions with museum staff about the storage, handling, display, and preservation of their cultural heritage, and from our understanding, the Mana Taonga policy is largely delivering this (Waitangi Tribunal 2011, 509).

\section{Iwi Exhibition Programme}

As discussed in the literature review, much academic writing discusses the power dynamics between museums and indigenous communities and the challenges by indigenous communities to authoritative narrative, voice and interpretation (Hooper-Greenhill 2004, Peers and Brown 2003). This is expressed by Ojibwa writer and storyteller Lenore Keeshig-Tobias who said, "when someone else is telling your stories in effect what they're doing is defining to the world who you are, what you are, and what they think you are and what they think you should be" (in Greer 1989, 11). The IEP at Te Papa is a response to the above discourse, offering a unique opportunity for iwi to tell their own stories of significance within a national forum (Te Papa n.d.).

Te Papa Board Member Api Mahuika from Ngāti Porou was a staunch advocate of including iwi exhibitions within the long-term Māori exhibit at Te Papa, Mana Whenua. Mahuika was adamant Te Papa provide a forum for iwi to express their cultural heritage in depth according to their tikanga - something the pan-tribal exhibition Mana Whenua would have struggled to do, having to cater as it did for Māori nationwide. When the national museum reopened in 1998, he declared, "Waiho, ma te iwi e kōrero" (leave it for the iwi to speak) (Hakiwai pers. comm. 12 Sept. 2006). Likewise, Māori scholars Ngahuia Te Awekotuku and Linda Nikora stress the 
importance of iwi exhibitions as they "allow for the telling of alternative and heterogeneous histories and versions which may have remained largely invisible or unknown to many audiences" (in Message 2006, 185). As museums question their traditional custodial role in relation to the living culture and people intimately connected to their collections, the IEP enables iwi to present themselves as distinct and vibrant tribes today with a living dynamic culture. Like many indigenous heritage movements "this should not be misinterpreted as simply nostalgia for the past, but a claim for the future based on a re-appropriation of traditional culture" (Sissons cited in McCarthy 2004, 137). Hakiwai explains that "Māori people are saying our present and future is inseparable from our past" (cited in Corsane 2004, 156).

Te Papa's IEP provides an opportunity for the museum to develop strong and enduring relationships with iwi and is the most visible form of iwi partnership and an important expression of the Mana Taonga concept (Te Papa website). Though the exhibition is a central focus, the iwi relationship extends beyond the exhibition. For the duration of the exhibition, the iwi are considered 'in residence' at Te Papa. They hold the paepae (orators' bench) of Te Papa's marae, host various events at the museum and contribute to Te Papa’s public programmes including the Matariki (Māori New Year) festivities. There are also economic opportunities for iwi, which include promoting tourism back in their tribal area and iwi artists being promoted in the Te Papa store. The iwi exhibitions also address issues pertaining to customary culture, which extends the iwi in residence beyond the exhibition to the museum's marae. Two kaumātua from the iwi are employed by Te Papa and assist the museum in tikanga Māori. The kaumātua also train and teach Te Papa staff in the performing arts, marae protocol and te reo (language). The kawa (protocol) of the particular iwi in residence prevails on Rongomaraeroa, Te Papa's own marae, for the duration of the iwi exhibition. Whether it is collections management or commercial opportunities, it is envisaged that the iwi in residence can participate and contribute across the range of the museum’s activities. Te Papa's team manager of the Iwi Relations Carolyn Roberts-Thompson, who was interviewed as part of this research, describes how the museum has continually refined the IEP and how the experience for Te Papa has been different each time. Roberts-Thompson believes this provides the museum with a positive challenge to remain responsive to iwi, "so we don’t get set in our ways and think that's the only way we can do it". She continues, "It's about breaking out of that box. There’s always lots of learning in this process which is good for us as an organisation," (Roberts-Thompson pers. comm. 8 May 2011). 


\section{Ngai Tahu}

Whakapapa is the essential underpinning element of Ngāi Tahu Whānui identity. It provides the basis of the Ngāi Tahu worldview, defines how Ngāi Tahu Whānui locate themselves in the Ngāi Tahu world and their relationship to it. It is the overriding determining factor in their associations to the land and place and the rights that derive from those associations (O’Regan cited in Te Papa 2005, 4).

Ngāi Tahu means 'people of Tahu' after the tribe's founder Tahu Potiki. Ngāi Tahu whānui as it is today is the collective of Ngāi Tahu, Ngāti Māmoe and Waitaha who are the individual hapū members of Kāti Kurī, Ngāti Irakehu, Kāti Huirapa, Ngāi Tūāhuriri and Ngāi Te Ruahikihiki (Te Rūnanga o Ngāi Tahu website, Te Ara website).

Today, Ngāi Tahu is the fourth largest iwi in New Zealand with close to 50,000 tribal members at the last census in 2006. Ngāi Tahu tribal members can be found throughout the world, though the majority (roughly 60 percent) continue to live within the tribal boundaries of Ngāi Tahu. Other places with large populations of Ngāi Tahu are Wellington, Auckland and Australia (Statistics New Zealand 2007). To enrol as a beneficiary of Ngāi Tahu, iwi members must be able to whakapapa, or trace ancestry back, to the official census list of all Ngāi Tahu living in 1848 , which is also known as the Blue Book.

\section{Ngäi Tahu Treaty of Waitangi Settlement}

Ngāi Tahu suffered dramatically through colonisation despite repeated attempts by petitioning Parliament and seeking redress in the Native Land Court to hold the Crown accountable for its destructive practices and breaches under the Treaty of Waitangi. In 1986, Rakiihia Tau lodged a claim with the Waitangi Tribunal on the behalf of the Ngaii Tahu Trust Board. The Tribunal held a comprehensive inquiry into Ngāi Tahu's claim and reported in 1991 that the Crown had "acted unconscionably and in repeated breach of the Treaty" (Te Rūnanga website 2011). Negotiations started and, in 1998, a Crown apology and settlement provided compensation valued at $\$ 170$ million. Ngāi Tahu was granted certain rights to sites of tribal significance and some role in managing conservation estate resources within the tribe's boundaries. The settlement also granted first right of refusal on the sale of Crown property and confirmed Ngāi Tahu's ownership of pounamu (greenstone). Sacha McMeeking, Ngāi Tahu General Manager of Strategy and Influence, says "the decision was to settle cheaply - accepting \$170m when even the Treasury 
estimated the value of dispossessed lands lay between $\$ 12$ and \$15 billion - so as to put past grievances behind and restart the conversation about forging a properly shared destiny"

(McCrone 2011). The obstacles Ngāi Tahu have had to endure over the last 200 years were best captured in a proverb by Ngāi Tahu kaumātua Hastings Tipa, who compared the Ngāi Tahu claim to the act of smoothing greenstone: he mahi kai hoaka, he mahi kai takata. It is work that consumes people as greenstone consumes sandstone. This proverb reflects the notion that just as it takes a lot of sandstone to wear away the greenstone, the Ngāi Tahu claim could only be achieved through the tenacious efforts of the people and the work of generations (Te Karaka 2006).

\section{Te Rūnanga o Ngāi Tahu}

Te Rūnanga o Ngāi Tahu (Te Rūnanga) was established by the Te Rūnanga o Ngāi Tahu Act 1996. It is the organisation that services the tribe's statutory rights and works on behalf of the iwi to manage its collective assets. Te Rūnanga ensures the benefits of the settlement are enjoyed by Ngāi Tahu Whānui and will grow for the future generations. Ngāi Tahu Whānui are grouped into 18 papatipu rūnaka or regional groupings throughout the South Island. An elected representative from each of the rūnaka makes up Te Rūnanga, the governing body overseeing the tribe's activities. Through this tribal council structure, Te Rūnanga is accountable to the tribal members (Rūnanga website 2011). The Office of Te Rūnanga also administers, monitors and delivers social and cultural programmes to its iwi members. Ngāi Tahu Holdings Corporation Limited manages the iwi's commercial activities which have turned a \$170 million settlement into $\$ 600$ million of assets, including a large seafood business and successful tourism ventures (McCrone 2011).

\section{Ngäi Tahu 2025}

Ngāi Tahu 2025 is the tribal vision document that expresses the aspirations for iwi development. It was envisioned by nearly 100 members of Ngāi Tahu Whānui, who came together between 1999 and 2000 'to dream the tribal future'. It was adopted as the prime strategic document of Te Rūnanga in 2001, which reports annually on its progress and is reviewed every five years (Ngāi Tahu 2001). At the last Ngāi Tahu 2025 Review in November 2009, Ngāi Tahu Kaiwhakahaere (Ngāi Tahu Chair), Mark Solomon described it as: 
A living document that captures the hopes and dreams of a generation - it's our road map that seeks to guide us - but over time maps change, new roads are created to new destinations, well worn roads need maintenance and repair, and some become the roads less travelled. I see the current Ngāi Tahu 2025 review is our time to have another tribal conversation. (Te Rūnanga website 2011).

\section{Mō Tātou: The Ngāi Tahu Whānui exhibition}

Ngāi Tahu is the fifth tribe to stage an iwi exhibition since Te Papa opened in 1998. The exhibition name $M \bar{o}$ Tãtou, chosen as the title and guiding principle for the exhibition by tribal elders, is drawn from Ngāi Tahu's tribal vision Mō Tātou, a mo ka uri a muri ake nei - for us and our children after us. The exhibition Developed Design document states "that the exhibition will present Ngāi Tahu as an iwi that values the past, plans for the future and looks to achieve new horizons; and that has cultural values which sit at the heart of all they are and do" (Te Papa 2006b, 4). Mō Tātou represents the first time a major collection of Ngāi Tahu taonga, stories and culture have been brought together in an exhibition. Kaiwhakahere (Ngāi Tahu Chair) Mark Solomon commented that "it's our time to tell our own stories, treasure our history, celebrate our contemporary artists and look forward to the future" (Te Karaka 2006, 13).

\section{Exhibition themes}

In describing the conceptual themes of the exhibition, Mō Tātou curator Megan Tamati-Quennell recalls how the four themes were drawn from the whakatauki, Mō Tātou, a mo ka uri a muri ake nei. "Well, if that's our guiding principle," she stated, "then what does that mean? How do you unpack that? What is it that you leave for your children? In the end we decided it was cultural values and how they are transmitted in a myriad of ways both customary and contemporary," (Tamati-Quennell pers. comm. May 8, 2011). The four themes of the Mō Tâtou exhibition are as follows.

Toitu te iwi - Culture: encompasses the origins of Ngāi Tahu Whānui with their own distinct creation story illustrated in an audio visual, and the 'rūnanga wall' emphasising the reempowering of papatipu rūnanga with representation through taonga and pepeha (set verses that describe whakapapa links to a particular hapū or iwi) each selected by the 18 individual rūnanga. The concept of the papatipu rūnanga being the backbone of the iwi is extended to the physical 
design of the rūnanga wall as the spine of the exhibition itself, and each display case being a vertebra.

Toitu te rangatiratanga - Tenacity: explores two important aspects that are symbolic of Ngāi Tahu's tenacious approach, namely whakapapa which is articulated by significant taonga and images of significant Ngāi Tahu Whānui. The second aspect is Te Kereme - The Ngāi Tahu Whānui Land Claim and Claim Settlement which is presented using a mix of art, objects, text and graphics including a facsimile of the Crown Apology and an audiovisual depicting Ngāi Tahu in its post-claim optimism and positivity.

Toitu te ao turoa - Sustainability: focuses on two significant cultural practices - mahinga kai (food-gathering practices) within Ngāi Tahu's unique natural environment and mahi raranga (weaving) showcasing the unique resources available in the South Island. The contemporary focus is centred on the tribe's relationship with the tohora (whale) and the sustainable commercial venture of Ngāi Tahu tourism's Kaikoura Whalewatch.

Toitu te pae tawhiti - Innovation: accentuates the relationship between past and present, and focuses strongly on the tribe's modern cultural dynamism. Pounamu is presented both from a historical and a future-focused perspective. Te reo and cultural revitalisation draws on elements from the 'Kotahi Mano Kaika, Kotahi Mano Wawata - A Thousand Homes, A Thousand Dreams' and its innovative approach to language regeneration. The third aspect within this theme was contemporary art and practice and provides a focused opportunity within the exhibition to present a large work by internationally recognised and nationally significant Ngāi Tahu artists (Te Papa 2005a, Te Papa 2005b, Te Karaka 2006).

The above themes were identified by the ISG and are descriptors of Ngāi Tahu's cultural characteristics. These themes demonstrate Ngāi Tahu as a distinct iwi with unique customary practice, such as the mahinga kai traditions, and contemporary practices, like the Kotahi Mano Kaika language revitalisation strategy, as well as Ngāi Tahu's distinctive world view as illustrated in their creation story (Te Papa 2005a). Curator Megan Tamati-Quennell explains Ngāi Tahu "saw this as an opportunity to say that while these themes are anchored by that customary culture, it pushes off into a more contemporary way of being" (McLean 2006, B7) 


\section{Design}

Compared to previous iwi exhibitions, which often presented a more sombre reflective mood with darker colours that evoked a respectful echo of the past, Mō Tātou was starkly contemporary in its display. It had a crisp, clean, cutting-edge ambience; its design included white walls, vibrant graphics reflecting the "flourishing growth and vitality within Ngāi Tahu", and sleek signage in a "futuristic form that represents the ideas of growth, communication and technology" (Te Papa 2005a, 57). Tamati-Quennell hopes the exhibition "breaks the ethnographic and anthropological frame that many Māori exhibitions are presented within" (Te Karaka 2006, 12) (see appendix 6-9 for floor plans and images of the gallery space).

\section{The personnel: Iwi Steering Group, Kaumātua and Curator}

For each iwi exhibition, Te Papa asks the tribe to identify a mandated curator and an advisory committee. Ngāi Tahu assembled an ISG to ensure the voice of the iwi was clearly represented in the exhibition and associated programme and events. The ISG was made up of selected iwi representatives with standing within their individual iwi communities and the Ngāi Tahu Whānui corporate structure. It was the ISG's role to "determine what content is or is not relevant or appropriate throughout the exhibition development process" (Te Papa 2006b, 3). The ISG membership consisted of Rakiihia Tau (Chair), Piri Sciascia (Deputy Chair), Jane Davis, Maika Mason, Te Ao Waaka, Koa Mantell, Charlie Crofts, Maria Tini and Edward Ellison. The ISG were also responsible for selecting who would represent Ngāi Tahu as the kaiwhakahaere pae (cultural leaders on the marae) for the duration of Mō Tâtou. Tau explains that to "occupy the role on the pae (orators' bench) Te Papa we needed to select an ambassador who houses both the traditional kawa (marae procedure) and also the spiritual hahi (beliefs) that forms the fabric of our two belief systems that intertwine to form the tikanga of our tribe" (Te Karaka 2006, 48). Kukupa Tirikatene and Maruhaeremuri Stirling, followed by Te Whe Phillips, were considered to have the necessary expertise for this onerous responsibility and were selected to be poua (kaumatua or male elder) and taua (kuia or female elder) at Te Papa while Ngāi Tahu were in residence.

Ngāi Tahu was fortunate in having Megan Tamati-Quennell as the curator for Mō Tâtou. Not only was Tamati-Quennell from Ngāi Tahu descent, but she had curatorial expertise within Te 
Papa, understood its organisational structure and hierarchy, and had also been working for the iwi for the past two years as an Arts Advisor. In an interview with Megan Tamati-Quennell, she states that she also drew on expertise of people like Tahu Potiki, Hana O’Regan, Marie Tau and Anake Goodall, "who weren’t on the ISG but had expertise in their particular field". She adds, "There’s no point in me going to anyone but our own people in the iwi" (Tamati-Quennell pers. comm. 8 May 2011).

\section{Mō Tātou:Te Hokinga Mai}

Mō Tātou opened in July 2006 at Te Papa with an unprecedented 2000 iwi members attending the dawn opening ceremony (see appendix 14). Media commentator Derek Fox exclaimed that "it seemed like every Ngāi Tahu on the planet was there, which was all the more remarkable because it was 3:30am, and outside Te Papa in Wellington" (2006, 82). The exhibition was on display at Te Papa until August 2009 - six months longer than initially agreed, as the next iwi to exhibit was not yet ready to occupy the Iwi Gallery. In a joint venture between Te Papa and Ngāi Tahu, Mō Tātou then toured throughout the South Island as Mō Tātou: Te Hokinga Mai. The exhibition package that toured was adapted at each venue to include more local content and creative expression. It first toured to the Canterbury Museum in Christchurch (February-June 2010) where the exhibition and taonga were 'welcomed home’. Here, Mō Tātou was presented alongside $M \bar{o} K a$ Uri, a companion exhibition "featuring more than 200 taonga from Canterbury Museum's reserve collections, many previously unseen" (Moore 2010). Mō Tātou then toured to the Southland Museum (July-November 2010), and was finally exhibited at the Otago Museum in Dunedin (December 2010-April 2011). Record visitor numbers to the Mō Tãtou exhibition were reported at all museums; 850,000 people attended Mō Tātou at Te Papa, Wellington. 26,844 visitors were recorded at Canterbury Museum, Christchurch. 35,352 visitors were reported at Southland Museum, Invercargill and 29,686 at the Otago Museum, Dunedin (Te Papa 2011). Rakiihia Tau regards Mō Tātou as similar in significance to Ngāi Tahu as the Te Māori exhibition (Te Karaka 2006). And just as Te Māori returned to New Zealand and Te Māori: Te Hokinga Mai toured the country in the 1980s, so the touring exhibition of Mō Tâtou: Te Hokinga Mai brings a new facet to the IEP, renews relationships between regional museums and local rūnanga, as well as further reconnecting Ngāi Tahu with their taonga and culture. 


\section{Condusion}

In this chapter I presented a summary background of the Ngāi Tahu Whānui exhibition Mō Tãtou by presenting a brief overview of the historical relationship between Māori and museums, including the ground-breaking exhibition Te Māori. I then introduced Te Papa's conceptual, legislative and organisational structure, followed by important concepts such as the museum's Mana Taonga principle and explored the intentions of its IEP. Following this, I provided background information about Ngāi Tahu, its tribal structure and governing body, Te Rūnanga, and provided a brief commentary on Ngāi Tahu's Treaty of Waitangi settlement and its visionary document Ngāi Tahu 2025. Lastly, I discussed the Mō Tātou exhibition, its themes, the design and key personnel involved, before finally describing the touring exhibition Mó Tâtou: Te Hokinga Mai. This provides a fuller understanding of the wider context within which the $M \bar{o}$ Tātou exhibition is situated. It will also assist in considering the findings and analysis of the iwi survey covered in the next chapter. 


\section{ChapterTwo}

The following chapter presents the quantitative data from the Ngāi Tahu iwi online survey conducted in May 2011 and examines its findings to construct an iwi perspective on the $M \bar{o}$ Tãtou exhibition. The purpose of the survey was to present Ngāi Tahu iwi members with an opportunity to answer questions and express their views about Mō Tātou. Although this research has led me through a personal journey concerning my own Ngāi Tahu identity, empowering my own Ngāi Tahu voice, I kept being pulled back to the importance of going to the iwi, to the people, to gauge their voice. It is important with any work that deals with kaupapa Māori - and research is no different - that the source community is involved. Through iwi members volunteering to participate in the survey, it also gave me a sense of tribal endorsement of the research.

The survey questions could be loosely grouped into three themes; the first section asked questions about the Mō Tâtou exhibition, secondly about cultural aspirations and identity, and lastly questions collating demographic data. Survey Monkey has a range of different types of questions you are able to use in your survey; these include multi-choice answers, comment box and rating scale (see appendix 15 for full format of the survey). The data is presented below with a brief explanation about each question. This is followed by further analysis and interpretation of that data, profiling a response from iwi members to the $M \bar{o}$ Tâtou exhibition.

\section{Survey Findings}

Q1: Do you affiliate to Ngāi Tahu, Ngāti Māmoe or Waitaha? (multiple choice - only one answer allowed)

\begin{tabular}{|l|l|}
\hline Answer option & Response count \\
\hline No & 4 \\
\hline Yes & $\mathbf{1 1 5}$ \\
\hline
\end{tabular}


This first question acted as a filter and asked potential respondents if they affiliated to Ngāi Tahu, Ngāti Māmoe or Waitaha (different tribal groupings which make up Ngāi Tahu Whānui as stated in the Te Rūnanga o Ngāi Tahu Act 1996). As the survey was only interested in responses from Ngāi Tahu Whānui iwi members, it was essential that this was the first question where only one answer was allowed, either 'Yes' or 'No'. Those respondents who said 'No' were exited from the survey and its results. I was satisfied with the response rate of the survey. Although the exhibition closed in April 2011, it has been on tour for the past two years, previously being staged at Te Papa from July 2006 to August 2009. This means for some respondents, it is possible they have not seen the exhibition for over four years.

Q2: Did you visit the Ngāi Tahu Whānui exhibition Mō Tãtou? (multiple choice - only one answer allowed)

\begin{tabular}{|l|l|}
\hline Answer option & Response count \\
\hline No & 11 \\
\hline Yes & $\mathbf{1 0 4}$ \\
\hline
\end{tabular}

The second question asked whether iwi members had visited the Ngāi Tahu Whānui exhibition Mō Tâtou. This was a binary choice, only one answer allowed question. If respondents answered 'Yes' they continued with the entire survey. However, if they responded 'No' that they had not visited the exhibition, then they bypassed the questions explicitly about the Mô Tãtou exhibition and were redirected to question 13 where they were asked about their own cultural aspirations and the Ngāi Tahu Find. Unfortunately, due to the limitations of using the Survey Monkey software, I was unable to split the survey and ask different questions to those who did not visit the exhibition and ask why they did not visit. However, as they had identified themselves as iwi members, I was still interested in their views of cultural identity, hence redirecting them to questions further in the survey. 
Q3: Where did you visit the Mō Tātou exhibition? (multiple choice - multiple answers allowed)

\begin{tabular}{|l|l|}
\hline Answer option & Response percentage \\
\hline Te Papa, Wellington & $\mathbf{7 6 . 1 \%}$ \\
\hline Canterbury Museum, Christchurch & $39.5 \%$ \\
\hline Southland Museum, Invercargill & $22.4 \%$ \\
\hline Otago Museum, Dunedin & $48.7 \%$ \\
\hline
\end{tabular}

As mentioned in chapter one, the Mō Tãtou exhibition toured the South Island after its show at Te Papa. This question enables multiple answers as some people visited the exhibition at more than one venue. Te Papa, which hosted the primary exhibition, was the most visited venue. It also hosted the opening ceremony where over 2000 Ngāi Tahu Whānui members attended. The Otago Museum hosted the very final closing ceremony after the exhibition had been open for five years and may explain why it was the second highest visited venue out of the four.

Q4: Did you attend any events associated with the Mō Tâtou exhibition? (multiple choice - only one answer allowed)

\begin{tabular}{|l|l|}
\hline Answer option & Response percentage \\
\hline No & $10.8 \%$ \\
\hline Yes & $\mathbf{8 9 . 2 \%}$ \\
\hline
\end{tabular}

As part of the IEP, events are organised around the exhibition to provide shared experiences and enhance the visit experience. Te Rūnanga also invested resources for iwi members to participate in the opening and closing ceremonies, as well as public programmes both at Te Papa and when the exhibition toured throughout the South Island.

Q5: Which events associated with Mō Tãtou did you attend? (multiple choice - multiple answers allowed)

\begin{tabular}{|l|l|}
\hline Answer option & Response percentage \\
\hline Workshops & $44.6 \%$ \\
\hline Performances & $63.1 \%$ \\
\hline
\end{tabular}




\begin{tabular}{|l|l|}
\hline Talks & $50.8 \%$ \\
\hline Tours & $23.1 \%$ \\
\hline Opening and/or closing ceremonies & $\mathbf{8 6 . 2 \%}$ \\
\hline Other (please specify) & $12.9 \%$ \\
\hline
\end{tabular}

This question covers the scope of what was offered in different programming events and what was utilised by the iwi. An 'Other' choice was also provided with a comment box for respondents to add any further event which was not listed. Respondents who chose this option specified Matariki celebrations, fashion shows and governance hui (meeting) as further events not listed in the above choices.

Q6: Why did you visit the Mō Tātou exhibition? (comment box)

\begin{tabular}{|l|l|}
\hline & Response count \\
\hline Answered question & 87 \\
\hline Skipped question & 32 \\
\hline
\end{tabular}

While initially the intention of the online survey was to acquire quantitative data for this dissertation, by asking open-ended questions and providing a comment box it also captured qualitative data from the respondent in their own voice. Responses included themes such as to learn more about their tribal identity or to reconnect to the iwi: "Because I wanted to get back in touch with my Kai Tahutaka, and thought this would be a good way to start", "We visited the exhibition to reconnect with Ngāi Tahu", "to give life back to my grandparents connections in the south, for me personally" and "To gain insight of what's important for Ngai Tahu". Others visited the exhibition as a statement of their Ngāi Tahutanga (Ngāi Tahu identity), to the support the kaupapa and the iwi's efforts; by being acknowledged and supported by the people this in effect gave mana or status to the exhibition: "To support the mahi [work] of our tūpuna [ancestors] and my Kāi Tahutaka", "Because I’m Ngāi Tahu", "Our whanau and iwi were on show, and it's important to support and tautoko [support] that" and "To witness the wonder of Kāi Tahu culture. And to make sure our exhibition was the best so far". Another theme that evolved from this question was people's value of taonga or their sense of being a kaitiaki or 
caretaker for the taonga: "For the opportunity to see taonga Ngāi Tahu gathered together in one place", "Opportunity to visit both our unique taoka \& enjoy the wairua [spirit] of our ancestors", "My tipuna were part of the display in the Tipuna Room along with their taonga. I felt it was my obligation to be there with them", "to view the diverse range of taonga that is displayed at one place at one time" and "to see the taonga of my people, my iwi. I love pounamu".

Q7: How did you find out about the Mō Tâtou exhibition? (multiple choice - multiple answers allowed)

\begin{tabular}{|l|l|}
\hline Answer option & Response percentage \\
\hline $\begin{array}{l}\text { Ngāi Tahu communications (e.g. Te Pānui } \\
\text { Rūnaka) }\end{array}$ & $\mathbf{7 2 \%}$ \\
\hline Mainstream media & $14.7 \%$ \\
\hline Whānau & $60.0 \%$ \\
\hline Word of mouth & $30.7 \%$ \\
\hline Other & $21.3 \%$ \\
\hline
\end{tabular}

This question enabled multiple answers as it is reasonable to acquire information from more than one source. The findings suggest that Ngāi Tahu Communications are effective in communicating with Ngāi Tahu Whānui iwi members and that, even in our contemporary world, whānau or family is still an important function and source of communication for Ngāi Tahu.

Q8: Who did you visit the Mō Tâtou exhibition with? (multiple choice - multiple answers allowed)

\begin{tabular}{|l|l|}
\hline Answer options & Response percentage \\
\hline Family & $\mathbf{8 6 . 8 \%}$ \\
\hline Friends & $53.9 \%$ \\
\hline On your own & $34.2 \%$ \\
\hline School or educational institution & $10.5 \%$ \\
\hline Other & $13.2 \%$ \\
\hline
\end{tabular}


Multiple answers were also used for this question to allow for those who visited the exhibition more than once with different groups of people or as an individual. As Mō Tātou exhibited the living culture and shared histories of Ngāi Tahu, it is perhaps expected that the majority of people visited the exhibition with their whānau who share the same tribal heritage.

Q9: Did you revisit the Mō Tâtou exhibition? (multiple choice - only one answer allowed)

\begin{tabular}{|l|l|}
\hline Answer option & Response percentage \\
\hline No & $17.1 \%$ \\
\hline Yes & $\mathbf{8 2 . 8 \%}$ \\
\hline
\end{tabular}

I considered whether people re-visited the exhibition or not a measure of the exhibition's success in terms of capturing iwi members as an audience that kept returning to visit the exhibition. In hindsight, I would have followed up this question by asking how many times people visited $M \bar{o}$ Tătou to add to the quantitative data.

Q10: Was visiting the Mō Tătou exhibition your first visit to a museum? (multiple choice - only one answer allowed)

\begin{tabular}{|l|l|}
\hline Answer option & Response percentage \\
\hline No & $\mathbf{9 2 . 1 \%}$ \\
\hline Yes & $7.9 \%$ \\
\hline
\end{tabular}

In terms of new audience to museums, I was interested to ascertain how many Ngāi Tahu Whānui members were new to the museum experience. Given the increasing partnerships between Māori and museums, particularly in the past 25 years, it is not surprising that such a large percentage of respondents had already visited a museum before their visit to the Mō Tãtou exhibition. 
Q11: Please read the following statements and rate them accordingly (rating scale)

\begin{tabular}{|l|l|l|l|l|l|}
\hline Answer option & $\begin{array}{l}\text { Strongly } \\
\text { agree }\end{array}$ & Agree & $\begin{array}{l}\text { Neither } \\
\text { agree or } \\
\text { disagree }\end{array}$ & Disagree & $\begin{array}{l}\text { Strongly } \\
\text { disagree }\end{array}$ \\
\hline $\begin{array}{l}\text { The } \text { Mō Tātou exhibition } \\
\text { enhanced my Ngāi Tahu } \\
\text { identity }\end{array}$ & $\mathbf{4 5 . 3 \%}$ & $38.4 \%$ & $10.9 \%$ & $2.7 \%$ & $2.7 \%$ \\
\hline $\begin{array}{l}\text { The } \text { Mó Tātou } \text { exhibition } \\
\text { reflected my cultural } \\
\text { aspirations }\end{array}$ & $35.7 \%$ & $\mathbf{4 2 . 5 \%}$ & $16.4 \%$ & $4.1 \%$ & $1.3 \%$ \\
\hline
\end{tabular}

This question incorporates a rating scale, which is a type of question from Survey Monkey where respondents are asked to consider a statement and rate them accordingly. This is to ascertain to what extent the exhibition enhanced tribal identity or reflected cultural aspirations.

Q12: Did the Mō Tâtou exhibition generate new cultural aspirations for you? (multiple choice only one answer allowed and comment box)

\begin{tabular}{|l|l|}
\hline Answer option & Response percentage \\
\hline No & $17.1 \%$ \\
\hline Yes & $\mathbf{8 2 . 9 \%}$ \\
\hline
\end{tabular}

This question pulled a large response in terms of identifying new cultural aspirations being generated by visiting the Mō Tâtou exhibition. The comment box also captured a useful insight into what these new cultural aspirations are. The majority of respondents expressed how the exhibition had ignited a desire to learn more about their Ngāi Tahutanga: "to learn my whakapapa", "I want to be more involved", "Left me wanting more connection to and with my Kai Tahu whanauka [relatives]", "to help my own whanau grow in their Ngai Tahutanga" and "I have aspirations to learn the Kai Tahu reo dialect". Another theme that emerged was about the arts and being inspired to produce artwork: "Sought out Ngai Tahu designs for raranga", "My artistic creative side was invigorated", "Definitely felt the pull to start carving pounamu" and "Encouraged myself and my daughters to do some weaving and get ideas for artwork". Respondents also commented that while the exhibition did not generate any new cultural aspirations it did consolidate their cultural aspirations held before visiting the Mō Tâtou 
exhibition: "It just affirmed them", "just reaffirmed what I was already thinking" and "While Mō Tātou didn't generate NEW cultural aspirations for me, it certainly strengthened and intensified my aspirations!" Others also made generic statements about Ngāi Tahu identity as opposed to their own cultural aspirations: "It made me proud to be Ngāi Tahu, it is important that we hold on to our identity, share it and live it." and "The opening ceremony showed me that a Ngāi Tahu renaissance was actually happening not just in words but in action".

Q13: What are your own cultural aspirations? (multiple choice - multiple answers allowed)

\begin{tabular}{|l|l|}
\hline Answer option & Response percentage \\
\hline Te reo & $76.1 \%$ \\
\hline Tikanga & $70.5 \%$ \\
\hline Whakapapa & $79.5 \%$ \\
\hline Whanau histories & $\mathbf{8 1 . 8 \%}$ \\
\hline Marae revival & $60.2 \%$ \\
\hline Mahinga kai & $46.6 \%$ \\
\hline Visual arts & $39.8 \%$ \\
\hline Performing arts & $39.8 \%$ \\
\hline Taonga & $59.1 \%$ \\
\hline
\end{tabular}

This question allowed for multiple answers as respondents' cultural aspirations could well include more than one facet of cultural practice. 'Whanau histories' was the most popular cultural aspiration shared by respondents, followed closely by ‘whakapapa', ‘te reo’ and 'tikanga'.

Q14: Are you aware of the Ngāi Tahu Fund? (multiple choice - only one answer allowed)

\begin{tabular}{|l|l|}
\hline Answer option & Response Percentage \\
\hline No & $25.0 \%$ \\
\hline Yes & $\mathbf{7 5 . 0 \%}$ \\
\hline
\end{tabular}


This question seemed a natural progression following on from the previous question and gauges whether respondents are aware of the tribe's effort to grow the cultural capacity through the Ngāi Tahu Fund.

Q15: Have you ever applied to the Ngāi Tahu Fund? (multiple choice - only one answer allowed)

\begin{tabular}{|l|l|}
\hline Answer option & Response percentage \\
\hline No & $\mathbf{7 1 . 3 \%}$ \\
\hline Yes & \\
\hline
\end{tabular}

While $75 \%$ of respondents were aware of the fund, only $28.7 \%$ had ever applied. Though respondents may not have personally applied for the fund, they could possibly have participated in an event which was resourced by the Ngāi Tahu Fund.

Questions 16 to 19 were obtained demographic data relating to gender, age, where respondents live and whether they are registered with Te Rūnanga. Out of the 115 Ngāi Tahu Whānui iwi members who completed the survey, 72 were female and 43 were male. $63 \%$ of respondents lived in the South Island, 30\% lived in the North Island and 7\% of respondents were from overseas. 93\% were registered with Te Rūnanga. There was a spread of ages ranging from under 25 to 75 and over; the 55-65 age group, however, was the majority with $26 \%$.

Q20: Do you have any final comments? (comment box)

\begin{tabular}{|l|l|}
\hline & Response count \\
\hline Answered question & 52 \\
\hline Skipped question & 63 \\
\hline
\end{tabular}

The final question was also an open-ended question, asking whether there were any final comments. The responses from this question reminded me of comments found in a visitor book used to accompany an exhibition and sit within the exhibition space at the old National Museum. The responses were wide-ranging including congratulating those involved with the development and running of the exhibition: "I would like to congratulate all the hard work the many people put into the project for a job well done" and "Keep up the damn good work you guys are 
doing!!!" An expression of iwi pride: "Mō Tātou was epic!" and "we have much to be proud of \& Mō Tâtou is the visual face of that". There were also those who looked to the future for what was next for Ngāi Tahu: "Let's hope we continue to hold / host similar events", "Look forward to the next exhibition", "More Mō Tātou exhibits. Let us see what the museums are hiding" and "really glad they toured the exhibition in Te Waipounamu, hope they publish a book". There were also some that questioned certain aspects of the exhibition, though this number was very low: "I was disappointed not to see a more prominent use of the $\mathrm{K}$ dialect in relation to the exhibition", "I don’t believe that the items reflect all of Ngāi Tahu Whanui. Many items were from the usual whanau... there are plenty of other whanau out there! Why not showcase some other whanau and ancestors?"

\section{Analysis}

The above data provides an intriguing insight into a tribal perspective on arts, culture and heritage through exploring Ngāi Tahu's response to the Mō Tātou exhibition. There are two prominent features that emerge from this survey’s findings: first, a measure of the exhibition's success in engaging with Ngāi Tahu Whānui, and secondly, a profile of Ngāi Tahu assembled in regard to their cultural aspirations and the Mō Tãtou exhibition.

Both quantitative and qualitative data from the survey can be used to evaluate the success of the exhibition. Primarily, Mō Tâtou was visited by $90 \%$ of respondents, with $89 \%$ of them attending an associated event. The opening and closing ceremonies that occurred throughout all the museums as the exhibition toured were the most attended events with a substantial $86 \%$ of respondents attending. Mō Tātou was largely revisited by respondents, with $83 \%$ of those who visited the exhibition returning for further visits. By investigating the motivations why respondents visited the exhibition, the overwhelming response was to learn and reconnect to their Ngāi Tahutanga: "I wanted to learn more about my heritage and experience it all". For some, it was to reinforce and strengthen their pre-existing Ngāi Tahu identity: "It is part of who I am", while for others, the exhibition provided an opportunity to express being Ngāi Tahu: "Because I’m Ngai Tahu and we have a responsibility as kaitiaki". Mō Tātou was also explicitly successful in that $78 \%$ of respondents either strongly agreed or agreed that the exhibition reflected their cultural aspiration. Furthermore, an astounding 84\% of respondents either strongly agreed or agreed that the Mō Tātou enhanced their Ngāi Tahu identity. The exhibition was also a catalyst 
in generating new interest among Ngāi Tahu in their cultural identity; $83 \%$ agreed that the $M \bar{o}$ Tâtou exhibition generated new cultural aspirations. These new aspirations were largely a desire to learn Ngāi Tahu identity, including learning te reo and whakapapa: "I have aspirations to learn the Ngai Tahu reo dialect". Artists were also inspired to create and produce new artworks: "My artistic creative side was invigorated". Comments from the final question allude to a sense of pride and optimism amongst respondents: "Absolutely fantastic from start to closure" and "What an awe inspiring journey".

The survey is also useful in providing a qualitative profile of the Ngāi Tahu Whānui and the Mō Tătou exhibition. A significant aspect that was evident in the data was that Te Rūnanga is successful in communicating with its iwi members and is a valuable communication source for the iwi. 72\% of respondents found out about the exhibition through the efforts of Ngāi Tahu Communications, which included publications of the Te Pānui Rūnaka newsletter and Te Karaka magazine, radio and online communications. Ngāi Tahu is conscious of the importance of communication strategies and articulated this in the Ngāi Tahu 2025 document by stating "communication technology is also providing new avenues for our people to be enriched and to contribute to our Ngai Tahutanga regardless of time and location" (Ngāi Tahu 2001, 17). Respondents of the survey are also considered to be connected with their families, with $60 \%$ finding out about the Mō Tātou exhibition through whānau members. This also alludes to the exhibition being spoken of among Ngāi Tahu whānau. This notion of the exhibition being interacted by whānau groups is also supported by $87 \%$ of respondents stating they visited the $M \bar{o}$ Tătou with family members. The top five cultural aspirations identified by respondents in question 13 were: whanau histories $82 \%$, whakapapa $80 \%$, te reo $76 \%$, tikanga $71 \%$ and marae revival $60 \%$. These aspirations are very similar to the key priorities identified by Ngāi Tahu at a Cultural Summit held in Puketeraki in 2005. There they identified whakapapa, te reo me ona tikanga (language and customary practice), mahi toi (the arts), whanau development and whenua (land) development (Te Rūnanga o Ngai Tahu website 2011).

\section{Condusion}

In concluding this chapter, I examined mainly through quantitative data the tribal response to the Ngāi Tahu Whānui exhibition, Mō Tātou. I presented findings and analysis from an online iwi- 
wide survey. I suggested that Mō Tātou was successful in attracting high visiting numbers among Ngāi Tahu Whānui, that iwi members eagerly participated in events associated with the exhibition, such as the opening and closing ceremonies, and that the exhibition not only reflected a Ngāi Tahu identity, but was also a vehicle for evoking new cultural aspirations among iwi members. The following chapter presents eight interviews with key people involved in developing the exhibition and provides investigation into the partnership between Te Papa and Ngāi Tahu, and further analysis of how Ngāi Tahu used the exhibition to enhance tribal identity and advance their cultural heritage aspirations. 


\section{ChapterThree}

'We're the perfect partner because we're never going anywhere', Mark Solomon

This quote from Te Rūnanga kaiwhakahaere Mark Solomon is a clear statement that Māori and particularly Ngāi Tahu consider themselves an obvious, if not ideal, partner for museums to establish and maintain relationships with. Solomon unequivocally refers to the long-term advantage for the museum in entering a partnership with Ngāi Tahu; one which is intergenerational. This chapter considers the implications of this statement by examining eight interviews with key stakeholders, who were closely connected with the development stages of the Mō Tãtou exhibition at Te Papa in Wellington, and the touring exhibition Mó Tãtou: Te Hokinga Mai throughout the South Island. In this chapter, I identify three central themes that emerged from the data by means of inductive analysis. These themes are 1. Ngā kawai o te kete: Partnership, 2. Tikanga Māori: Customary Cultural Practice, and 3. Ngāi Tahutanga: Identity. Each theme is then broken down again into sub-sections which is followed by an analytical commentary and interpretation of the data presented in each section.

\section{Ngā Kawai o te Kete: Partnership}

The first theme that emerged from the interviews was concerned with relationship-building and partnerships. With any iwi exhibition there are layers of relationships, both internally within the museum and within the iwi, and then obviously between the museum and iwi. There is a lot of emphasis on relationship-building at the development stage of any exhibition. However, Te Papa and Ngāi Tahu were not total strangers; Mark Solomon, who is Te Rūnanga's kaiwhakahaere, was also on Te Papa's Board and it was here, in the boardroom, where initial dialogue started when Ngāi Tahu were being considered as the next iwi exhibition at Te Papa following Whanganui's Te Awa Tupua exhibition. As Piri Sciascia, Deputy Chair of the ISG explains, Ngāi Tahu felt at ease entering into their relationship with Te Papa in regard to the exhibition: "knowing that the place you're going to is receptive, operates in a way that is comfortable and that recognises our people had something to offer". 


\section{Mana whenua}

While the principal partnership was between Te Papa and Ngāi Tahu, Ngāi Tahu was also very aware that $M \bar{o}$ Tātou was not only being exhibited at Te Papa but in Wellington, Te-Whanganuia-Tara and was therefore very conscious of connecting with the mana whenua and local iwi of Wellington. This process was led by the ISG's first Chairman, Rakiihia Tau. As ISG member and Chair of the Ngāi Tahu Fund, Jane Davis describes "his view was, first, we needed to have a good rapport with the tangata whenua, then we would work on having a good relationship with Te Papa". This renewed relationship between Ngāi Tahu and local iwi Te Atiawa and Ngāti Toarangatira also opened opportunities for mana whenua to be considered and integrated into the exhibition. This occurred on two occasions. First, the opening of Mō Tātou in July 2006 when Te Atiawa and Ngāti Toa led the karakia at the opening of the exhibition at the invitation of Ngāi Tahu. There are a number of reasons why this occurred; first and foremost it drew on an old tikanga of inviting another iwi to open an event or wharenui (ancestral house), a process of enhancing relationships between tribes or hapū, which is also seen as a sign of humility. Secondly, it was a way of acknowledging Te Atiawa and Ngāti Toa as mana whenua as it was not considered tika or 'right' to exclude them in any cultural ceremony. Lastly, Ngāi Tahu was in a process of developing its cultural capacity on the marae and it was an obvious strategy to include mana whenua who had experience and expertise in this area.

Before the opening of the exhibition, Ngāti Toa's involvement in Mō Tātou was facilitated by a change of display with the proposed mere pounamu (greenstone weapon) case. Because of the weaponry nature of old mere pounamu and their association with bloodshed and killing, ISG member and leading pounamu exponent Maika Mason requested for all the mere pounamu to be separated from all other taonga. Mason made the curatorial decision, based on tikanga, to have a case of mere pounamu only in the exhibition (see appendix 13). Tamati-Quennell explains that, "because of the shift in emphasis with the mere pounamu, it was suggested to look to find more mere pounamu for the new display case" (Tamati-Quennell pers. comm. 7 Oct. 2006). ISG member Edward Ellison suggested including the mere pounamu Tuhiwai because of its historical connection. Te Matenga Taiaroa of Ngāi Tahu gifted Tuhiwai to Ngāti Toa chief Te Rauparaha as part of a peace settlement or tatau pounamu between the two tribes after hostilities in the 1830s (Te Ara website). Members of the ISG met with the Trustees of Tuhiwai to tono (request) 
for the mere pounamu to be included in Mō Tâtou. The overarching themes of the exhibition and the context in which Tuhiwai would be displayed were also presented. The Trustees agreed to loan Tuhiwai to the exhibition primarily because of the whakapapa relationship between the Wineera family of Ngāti Toa and the Taiaroa family of Ngāi Tahu (Tamati-Quennell pers. comm. 7 Oct. 2006).

Project manager for Mō Tãtou: Te Hokinga Mai and previous Collections Service Manager at the Canterbury Museum, Puamiria Parata-Goodall, explains:

One of the by-products of Mō Tätou is the strengthened relationships with other iwi. Mō Tãtou was sitting in Wellington which led to engagement and exposure to other iwi, because you can quite easily sit in your own little rohe [boundaries] but when you're forced to step out of that and engage on a national level, that's a whole new exposure... You are far more conscious that the relationships you build are beneficial for everybody. It's just not the discussion over the table because we're fighting over a boundary but it's asking 'what's important to you?', 'this is what is important to me' and how we can build this relationship. It ends up growing all these wonderful tentacles from that relationship.

In interviewing the Ngāi Tahu personnel, I asked about establishing relationships in the developmental stage of the exhibition. Although I was expecting them to respond about the relationship with Te Papa, they all referred to the importance of the relationship between Ngāi Tahu and Te Atiawa and Ngāti Toa as the mana whenua of Wellington. This response provided an interesting insight into the relationship dynamic between Māori and museums. Although it may seem obvious, it is often overlooked that the iwi will engage with museums within the tikanga Māori framework - an understanding of Māori customs and practices. As demonstrated by Ngāi Tahu's value in establishing a relationship with mana whenua.

\section{A partnership between equals - the capacity of Ngāi Tahu}

Ngāi Tahu is a progressive iwi and entered into a partnership with Te Papa on a much more equal footing in resources than other iwi exhibitions. Team Leader of Te Papa Iwi Relations, Carolyn Roberts-Thompson explains that Te Papa needed to adapt as a lot of Te Papa staff had not worked with an iwi that was as well-equipped as Ngai Tahu:

For Te Papa, some of the things the organisation struggled with when we entered this relationship with Ngāi Tahu was because Te Papa hadn't worked with an iwi as corporately savvy as Te Rūnanga who were post settlement looking to the future and 
it pushed us and brought in a whole lot of questioning into the process which was great, because we might not have been asked that by other iwi.

Piri Sciascia recalls that Ngāi Tahu had the ability to work with Te Papa and engage because it had the organisational capacity and had people with competence. He stated that "from a Ngāi Tahu point of view, we could arrive at meetings, we could write papers, we could negotiate". Tamati-Quennell describes the style of partnership between Te Papa and Ngāi Tahu as a real evolution, saying:

For me that was a real partnership. It was much more equal than maybe it had been previously and because of the way in which Ngāi Tahu operate. They are very sophisticated, they have their communications strategy. You know if you needed something sent out then you've got mechanisms like Te Pānui Rūnaka where information goes out to every tribal member or the magazine Te Karaka. They had called a cultural summit where they talked about the ideas.

This was endorsed by Carolyn Roberts-Thompson who noted that through their partnership with

Ngāi Tahu, "Te Papa learnt how well connected a tribe can be and the influence a tribe can have on a political scale and on an economic environment and within this cultural sector that we work in". Ngāi Tahu's ability to enter into the partnership with Te Papa with such an organisational capacity and financially resourced is directly linked to their status of a post-Treaty settlement iwi. It provides an encouraging example to Māori and indigenous communities internationally about what can be achieved and how source communities can operate once colonial grievances are settled.

\section{The Curator}

The appointment of Megan Tamati-Quennell as a curator for Mō Tātou was a significant factor in the development of Mō Tātou and, furthermore, how Te Papa and Ngāi Tahu established and maintained their partnership. During her interview, it becomes apparent that Tamati-Quennell had to endure a lengthy and continually negotiated process in advocating and injecting the iwi voice within Te Papa. She explains:

That was my role. I was at the front, I knew how the system worked, I knew how to get the resources, and I know how to make the things that need to happen happen to ensure that Ngāi Tahu's voice was in there. And the beauty with being a curator is that that's my job, I know how to do all that, but for someone who didn't... tough, man. 
Tamati-Quennell was also clear that between Ngāi Tahu’s Mō Tātou Project Manager Vicki Ratana and herself they would manage the massive volume of communication to and from Te Papa. She explains this was not to control the information, rather to "limit twelve people saying twelve different things to twelve different people so it doesn't get too dispersed and you know who gave the authority for the go ahead. Vicki and I were like the two conduits to facilitate the flow of information". Even obtaining sign-off from both parties became quite an exercise. Tamati-Quennell describes how:

You're speaking on behalf of the iwi, so everything had to be run through a lot of people. There was the internal Te Papa sign-off process and then there was the iwi steering group's sign-off process, so if there were any changes then it had to go back there, and if they wanted any changes then it had to go back there again, and that going back and forth happened.

Having such a knowledgeable 'insider' allowed the ISG, who were a much older group of respected kaumātua, to have more of a governance role over the development of the exhibition and liaise with Te Papa at a higher level. Tamati-Quennell recalls, "it felt like the ISG said we've got a big stick, Megan, and we're going to give it to you and we don't want to see you use it but, please, do if you need to".

Although Tamati-Quennell was very clear that she was there to represent the iwi, she was continually questioned whether her views were her own ambitions or that of the iwi (TamatiQuennell pers. comm. 26 Oct. 2006). Tamati-Quennell was also uncomfortable with the title of 'Subject Expert'. Although she had the curatorial skill base, she felt she was by no means a subject expert on Ngāi Tahu, nor did the title fit within a Māori paradigm when she often had to seek advice from other iwi members, including kaumātua. Tamati-Quennell questioned the museum in that the expertise actually operates outside of Te Papa. She explained that although "Te Papa might have the mechanism or the expertise about how to put the exhibition together, the content and the stories were really generated from outside. It's their knowledge not Te Papa's". Another issue of roles and position titles arose in the development stages of Mó Tâtou, when Tamati-Quennell expressed disapproval of anyone apart from the ISG being considered the 'concept developer'. She felt very strongly that there did not need to be a concept developer from Te Papa, as that was the role of the iwi. Because the concepts and themes for the exhibition were developed by Ngāi Tahu, Tamati-Quennell argued that "they did not need to be filtered, rewritten 
or amended by Te Papa" (Tamati-Quennell pers. comm. 26 Oct. 2006). This was a clear indication from Ngāi Tahu that they were not only interested in providing the cultural knowledge and material for the exhibition, but that they would interpret that cultural knowledge and material and make decisions on its display.

There were times where tikanga Māori and commercial corporate interests clashed. In times of tension, Te Papa staff and iwi found that dialogue and finding creative and innovative solutions paved the way forward. In one instance, Ngāi Tahu came up with the idea of having their mountain Aoraki as the image to use for marketing. The iwi wanted only the mountain used, as Aoraki is a strong symbol of their identity. The marketing team at Te Papa, however, wanted to put people on the mountain in a belief that it would be more successful in attracting visitors to the museum. Ngāi Tahu disagreed, as it would be culturally inappropriate for images of people to be placed at the summit of the mountain, a place considered highly tapu. There was also concern that in accordance with Ngāi Tahu custom, if any of the people used in the image were to die, that the whole image would have to be redone as images of people who have passed away were not to be displayed with images of people who are living. This issue was eventually resolved through a creative and innovative solution - Ngāi Tahu's most significant taonga were combined with the mountain in the image (see appendix 5). A compromise does not always satisfy everyone, but it did provide results and a way to proceed (Tamati-Quennell pers. comm. 26 Oct. 2006). In another instance, Tamati-Quennell explains that she stopped the designer drawing kowhaiwhai (scroll patterns) everywhere, because "it was her interpretation of what Māori is, almost a kind of Northland version of whakairo [carving] or kowhaiwhai and I said 'you know what, that's not as visible in the South'. I kept saying to her 'It's actually about the absence of those things, there’s more concrete monuments'". This resulted in graphics for the exhibition being "derived from natural raw elements such as rock and earth" (Te Papa 2006, 52) (see appendix 7-9).

\section{Te Papa - Iwi Relationships Team}

There were many challenges when designing and developing $M \bar{o}$ Tātou, as there are for any exhibition where ideas and views are shared and contested. Nevertheless, Ngāi Tahu were very generous in their praise of Te Papa, particularly the Iwi Relationships Team (IRT) and Māori staff who worked hard within their own organisation to allow Ngāi Tahu a voice throughout the 
museum. Davis recalls that "the Māori staff really came on side and took us into their hearts". Ratana also expresses her gratitude "the Iwi Relationships Team were great to work with and very accommodating to our requests which sometimes were above and beyond, and that's credit to that iwi relationship team". Parata-Goodall who had previously worked at the Canterbury Museum, was interested to observe professional practice from the other side of the coin, working with the iwi, the source community rather than the museum:

Coming from a museum background and knowing what the processes are that are happening behind closed doors that iwi aren't necessarily aware of and the number of processes that you go through, I have to say that I was greatly impressed with how Te Papa engaged. Quite often I know from a museum background, you couldn't have paid us to do what Te Papa was doing because it was completely in opposition to what you're trained in a museum to do. I know there must of been a couple of times where Te Papa must of been pulling their hair out because 'good museum practice' would tell you not to do a, b, and c but here were an iwi coming in and saying 'Well, actually our view of the world is te mea, te mea' and Te Papa going 'Kei te pai and doing it, knowing very well that it wasn't standard practice. But because they were true to the iwi relationship and saying the iwi will direct us and we will do the best we can to meet that, they did exceedingly well. It must have drove them nuts behind back doors.

Parata-Goodall highlights a valuable example set by the IRT and Māori staff at Te Papa. Their approach in accommodating Ngāi Tahu's customary practice in regard to their taonga and balancing that with museum practice can be articulated by the customary concept of manaaki, which in its simplest form means 'to care for'. To care for something or someone is different from tolerating or accommodating them; it implies that you care how someone is feeling and what they are thinking. It extends beyond egocentrism and provides a deeper level of relationship in any partnership, including that between museums and iwi.

Carolyn Roberts-Thompson explains that being able to be flexible and solutions-focused is critical for staff in the IRT to be responsive to iwi. Perhaps this is why Te Papa does not have a formal written policy. It could be perceived to be restrictive as Roberts-Thompson shares, "You do need to be nimble, because otherwise if you are so constrictive you don't bring about the best results, not only for Te Papa but for the tribe". Sometimes this philosophy of flexibility can cause tension within the museum itself, with some staff used to the structured museology processes that Te Papa has established to develop an exhibition to deliver a final product of quality, on time and on budget. Roberts-Thompson describes the IEP as a very organic and evolving programme. She goes on to explain that this: 
Doesn't always sit well with some people in the organisation; for Māori staff, that's just how we do it. We will do whatever it takes to manaaki the tribe and figure it out and to help realise what it is they want to achieve and therefore the model has adapted over the years. Some people struggle with that, but I think it's actually really healthy for this organisation to be able to experience something like that and be able to be quite quick in its thinking and its reaction to respond to our people. Because we know that one size doesn't fit all and that's what we've learnt from each of these experiences with the iwi that have participated in this programme.

The museum-iwi partnership also allowed Ngāi Tahu to learn and understand more about museum practice and why things are done a certain way. Vicki Ratana explains that an appreciation grew within Ngāi Tahu for what museums do because "a lot of our Ngāi Tahu whānau saw the benefit and understood museum practice in a new way and were given access to back of house and access to our taonga in their collection. I know a lot of our rūnanga also accessed a lot of the National Services Te Paerangi assistance". Parata-Goodall also recalls how for many Ngāi Tahu, they lost that suspicion of museums, that feeling that "you've come here to steal my stuff and collect it. An understanding grew that if these people didn't come along and pick up my tipuna’s taonga and stored it well they might not be here today". This last comment highlights the reciprocal relationship that can grow from the IEP and illustrates that source communities, such as iwi, can also benefit and learn from museology and museum practice.

\section{Relationships - above and beyond the exhibition}

While the emphasis at the beginning of the partnership centres on the development stage of the exhibition, this changes once the exhibition is opened and the iwi have been welcomed to the museum. From this point on, they are in residence and so an operational working relationship develops which is above and beyond the ongoing iwi exhibition. Ngāi Tahu kaumatua assist Te Papa with their day-to-day business of operating the museum's marae, providing cultural expertise to museum staff and ceremonially welcoming visitors to the museum, as well as opening other exhibitions throughout the museum. On top of this busy schedule dealing with the wide range of activities at Te Papa, the museum itself as an organisation was going through a lot of challenges. "We had gone through a restructure so there was uncertainty in the organisation about who was going to do what", recalls Carolyn Roberts-Thompson, "even when Ngāi Tahu arrived there were some big chunky issues and challenges that the organisation was dealing with." She said, "It was not easy but having their [Ngāi Tahu] support made a difference." The 
Ngāi Tahu kaumatua particularly helped the morale of Te Papa staff, because "the kaumatua breathe life into the organisation". There were also internal issues within Te Papa's senior management. Ngāi Tahu was in residence during the appointment and the arrival of new Kaihautu Michelle Hippolite, the tragic death of Te Papa’s Chief Executive Seddon Bennington and the appointment of Michael Houlihan as the new Chief Executive.

With the Mō Tātou: Te Hokinga Mai exhibition touring throughout the South Island after the Mō Tãtou exhibition was staged at Te Papa, Ngāi Tahu also developed its relationship with other regional museums. These relationships created an opportunity for local rūnanga to collaborate with their regional museum to exhibit the show with touches of local flavour added. With such a positive precedent set by Te Papa and Ngāi Tahu at a national level, it was now felt the right time to follow that through to a regional level. The Canterbury Museum, Southland Museum and Otago Museum all capitalised on this opportunity to host Mō Tātou. These events were a new dawn in the long-term museum relationship with Ngāi Tahu and local rūnanga. "It’s changed the place of local Māori and museums in Invercargill, Dunedin and Christchurch by just being there," commented Piri Sciascia, "It’s changed it forever". Each individual regional museum was at a different stage in their relationship with local rūnanga. Some had processes in place but they were not active, others had had struggles over collections and particularly perceptions of disputed ownership and decision-making with the collections. Parata-Goodall observed the growth in understanding at the Canterbury Museum. "We had this amazing exhibition and an amazing complimentary exhibition" she reveals, "and to see by the end of the four-month period how much they (Canterbury Museum) grew and actually realise there's benefits from working with iwi and understanding why you do these things." At the final closing of the Mō Tãtou exhibition in Dunedin in April 2011, Graham Crombie, recently appointed Chairman of the Otago Museum Trust Board, expressed the thought that "from a museum perspective we learnt a lot, so thank you, we will use this to our advantage in the future". Also at the closing ceremony of the exhibition Piri Sciascia, speaking on the marae, acknowledged the local rūnanga who had worked with the regional museums in the touring of Mō Tâtou: Te Hokinga Mai, in the process maintaining such a high-quality exhibition. "That's the legacy of bringing the kaupapa back to the people, tukuna te mana whakahaere ki te iwi," he said, "It doesn’t need an ISG for that. So thank you to our iwi whānui for picking up this kaupapa and running it so magnificently with our local museums." 
This theme of partnership: ngā kawai o te kete, illustrates the complexity of establishing a relationship and operational partnership between the museum and iwi. The qualitative data from the interviews clearly illustrate that there is no clear linear relationship between two structured identities; rather, there are various strands of the relationship, each woven together, interrelated and connected. This theme also examines the curatorial role and touches on the myriad issues and challenges curators face when working with iwi exhibitions. It also explores Ngāi Tahu's relationship with Te Papa above and beyond the exhibition staged at Te Papa. This included Ngāi Tahu being in residence at the museum, during which time Ngāi Tahu kaumatua are employed by Te Papa. Relationships are also extended to regional museums throughout the South Island, as Te Papa in partnership with Ngāi Tahu toured Mō Tātou: Te Hokinga Mai. And finally, tikanga Māori is highlighted as an influential characteristic of the iwi-museum relationship. This is demonstrated by Ngāi Tahu in acknowledging and engaging with the mana whenua of Wellington, and the role manaakitanga can play contributing towards a successful partnership.

\section{Tikanga Māori: Customary Cultural Practice}

The second theme that emerged from the interviews interwove concepts of tino rangatiratanga, mana and kaitiakitanga. These concepts are so central to the Māori world view that it is not surprising that they surface when researching kaupapa Māori. In Te Papa’s most recent exhibition E Tu Ake, senior curator Dr. Huhana Smith describes tino rangatiratanga in a modern context. "For Māori today, the term tino rangatiratanga sums up their capacity to have control over, or determine the course of things Māori", she writes "their resources and their way of organising and expressing themselves in the destiny they aspire to, as a people uniquely related to and identified with Aotearoa New Zealand" (2011, 22). To many this is a journey, an ongoing continued process of either obtaining your tino rangatiratanga or maintaining it. Mana is also an important concept to Māori. Smith goes on to say that "for self-determination, mana is a force that gives it energy... it promotes qualities such as integrity, dignity and self-respect ... [and] is expressed in authority and leadership that in turn empower others" (2011, 94). Mana as a concept is fluid and of course can be found in many spheres including as an expression of partnership. Smith argues that "mana is something that can be lost when relationships go astray and restored when they are repaired" $(2011,95)$. She brings these concepts together when describing 
kaitiakitanga. "In the journey towards tino rangatiratanga", she explains, "kaitiakitanga is the principle that applies the connectedness of whakapapa and the energy of mana to the places and situation where Māori live and draw their resources from" $(2011,146)$. Therefore kaitiakitanga is about having a responsibility and being able to enact guardianship, whether it is over taonga or other natural resources.

\section{Tino rangatiratanga}

In the case of the Mō Tātou exhibition, Ngāi Tahu clearly demonstrated their tino rangatiratanga not only in the development of the exhibition but in the style of relationship they had with $\mathrm{Te}$ Papa. Jane Davis told me that "The internals within Te Papa probably saw us as a little different because I think as Ngāi Tahu people we're pretty much our own people. We will not always follow what is considered the norm and our exhibition is different from the exhibitions that have preceded us." Jane Davis noted that Te Papa soon recognised that Ngāi Tahu were happy to listen, "but we'll be guided by what we think is right to do". Piri Sciascia also mentioned that "Ngāi Tahu was growing its mana in terms of one of the post-Treaty settlement iwi and making a presence and contribution at the table."

Rakiihia Tau, who was the first Senior Chair of the ISG, is explicitly acknowledged for providing strong leadership for Ngāi Tahu. Poua Kukupa Tirikatene explains that "the iwi voice was heard loud and clear. We had rangatira to rangatira talk; Rik and Wira the Chairman of the board." Jane Davis adds that "his understanding of tikanga gave us a really good steer. He is very firm in his convictions and doesn't really veer off from what he believes is right in a certain situation." ISG Deputy Chair Piri Sciascia went as far as to say "I breathed a big sigh of relief when I heard our leader of the committee engaging as a Māori on our iwi's behalf. Ka tau rangatira ake i runga i te hinengaro Māori, i tona wairua Māori". Sciascia describes the museumiwi relationship between the ISG and Te Papa very much pitched at a governance level as "rangatira to rangatira". He went on to say:

For me Rakiihia's leadership in particular was crucial because he wasn't contained by the table. He operated as an elder of the marae, of the people, the paepae upoko concept... kia ora you lot, you could be gone tomorrow, but we'll still be here because of our pa, our marae, our people. It wasn't their authority that put him there; it was their recognition of his authority. 
Tamati-Quennell also recalls Rakiihiria’s leadership during the exhibition development stage: "Rik Tau was very keen for Ngāi Tahu to do the audio visuals and because it covered the creation story and included whakapapa, he didn’t want Te Papa owning it." The audiovisual was so important for Ngāi Tahu to insist on retaining their tino rangatiratanga of certain aspects of the exhibition, such as whakapapa or genealogy that they were prepared to pay for the production of the audio visual. Te Papa paid what it had budgeted for the audio visual and Ngāi Tahu made up the difference, which ended up being twice the amount Te Papa had given to produce the audio visual. Tamati-Quennell fully supported Tau's call for Ngāi Tahu to make all the audiovisuals. For her it made more sense for Ngāi Tahu Communications to do the job instead of making them in-house at Te Papa. She explains, "I thought, well they don't know the people and what's the point of getting Te Papa to interview people who neither don’t know you nor trust you". She continues, "Te Papa didn’t know the history or what questions to ask". The result was a state-of- theart audio visual positioned at the entry point to the exhibition showcasing Ngāi Tahu's point of difference, "expressed through their own specific creation story, art forms, natural and cultural resources unique to the people of Te Waipounamu" (Te Papa 2006a, 14). Although the audio visual covered the context of the creation story, arguably the oldest story of Ngāi Tahu, it was presented in a manner so that visitors were in no doubt that Ngāi Tahu were a people firmly in modernity.

Another area where Ngāi Tahu expressed their authority was on the paepae at Rongomaraeroa, Te Papa's own marae. This may have been a challenge for Ngai Tāhu initially as they were still developing kaikōrero (male orators) and kaikaranga (female callers/orators). However, Sciascia was very clear that while there might not be the quantity of people yet from Ngāi Tahu to perform and lead paepae activities such as pōwhiri (formal welcomes) and openings, they did have the quality, both in terms of cultural values and expertise. Ngāi Tahu were very confident leading in their own tikanga and doing what felt right for them in ceremonial and paepae activities, rather than following what other iwi had done before them at Te Papa. Sciascia explains what happened on the paepae:

Kukupa brought his own spirituality which was Ratana and his way of doing it, which was not where Te Papa was in terms of what Tuhoe and Whanganui had been doing, and had become ingrained. But we put a dent in it because there had been some very strong cultural wananga and tapu put there that wasn't our spirituality. So the first thing we did was to put the paepae onto the other side of the marae according to our 
kawa. It had been changed by a previous iwi with all their reasons as to why it should be on that side. But the point was done to establish our authority so that Te Papa really got to live by their rule, which was not 'We have had the light shone upon us by this particular iwi', no no your rule is 'When the iwi come in you live and operate according to their kawa' as they will change again because the next one coming in will be Tainui and will be tau utuutu [alternating speakers] people so that will be quite interesting to see what happens there.

Ngāi Tahu were very mindful too that when Mō Tātou closed and left Te Papa there was not another iwi ready to hand the paepae over to, and did not want to leave themselves open to criticism that Ngāi Tahu had abandoned the paepae at Te Papa. It was agreed that the paepae was to be handed back to Te Papa with the support of mana whenua. Ngāi Tahu also significantly contributed to the Kura Pounamu exhibition where Ngai Tahu’s rangatiratanga over pounamu was readily accepted by Te Papa. Kura Pounamu was created as a placeholder exhibition until Tainui were ready to take their place in the iwi gallery space. At the closing of Mō Tātou, Ngāi Tahu were reminded that, although the exhibition had closed, the relationship with Te Papa is still alive and that Ngāi Tahu should be involved and return to the museum for both the closing of Kura Pounamu and the arrival of Tainui. "Just when you think it’s all over guess what", Sciascia commented, "and that's always a good lesson about kaupapa Māori".

As a result of tribal efforts in revitalising the Māori language and increasing the number of Māori speakers within Ngāi Tahu, there was substantial growth over the five years of the exhibition in the area of developing kaikorero, kaikarakia and kaikaranga (those responsible for speaking, leading prayer and calling). At the time Ngāi Tahu gathered at the Otago Museum to close $M \bar{o}$ Tātou they were able to produce eight kaikarakia and seven kaikaranga to perform the closing ceremony, resulting in a meaningful expression and momentous statement of Ngāi Tahu's mana. Both men and women were included, amalgamating karakia and karanga. Both the men and women met on their own during the day before the closing ceremony, to wananga (meet) and to decide how it would all unfold; in what order would they go and designate specific areas for each kaikarakia and kaikaranga (see appendix 10). Although the majority of ISG members were present for the closing in 2011, the committee had been disestablished and had not met before the day of the closing to discuss protocol together. Sciascia reveals that one of the things that they might have done was to invite elders from Ngāti Toa and Te Atiawa who had opened the exhibition at Te Papa back in 2006 to be with Ngāi Tahu at the closing. Piri Sciascia explains: 
But by this time there had been so much cultural growth in it that there we were at the opening with the gesture to allow another iwi to open it for us at our invitation and establish that relationship and yet when it came to the finish we had kaikarakia and kaikaranga by the dozen and did it in a new way with the women, which we couldn't even conceive of seven years ago, (five years exhibiting and two years planning). But there we were - full control (see appendix 11).

Returning to the literature, Lidchi's idea of the poetics and politics of display can also provide a useful analogy to interpret the qualitative data raised in the interviews about the rangatiratanga of Ngāi Tahu. The research clearly provides examples of the poetics and politics of rangatiratanga. The "practice of producing meaning" can be applied to rangatiratanga in the display of the tribe's collaborative efforts in the final closing ceremony of Mō Tâtou. And the politics of rangatiratanga can be seen in the 'production' of rangatiratanga and the authority-knowledge relationship, as illustrated when Ngāi Tahu insisted on producing the audio visuals to retain their tino rangatiratanga over their cultural knowledge $(1997,167)$.

\section{Mana}

During Ngāi Tahu's residency at Te Papa, there were two particularly important issues where Ngāi Tahu, standing on its tribal mana and as a Treaty partner, challenged Te Papa. The first was about an exhibition called Egypt: Beyond the Tomb which recreated the ancient Egyptian world of the dead and followed Keku, an Egyptian woman who lived 2700 years ago. The exhibition featured a breadth of burial treasures including mummification tools, coffins and the actual mummy of Keku (Te Papa website). For Ngāi Tahu the display of Keku was culturally offensive as it included human remains as part of the exhibit. Therefore Ngāi Tahu challenged Te Papa that they were in breach of their own policy on human remains and also contradicted the efforts of Karanga Aotearoa (Repatriation Team) in the return of human remains from overseas museums. Te Papa's own Kōiwi Tangata Policy states in section 5.6 that "At no time will any kōiwi tangata or waka tupapaku (burial chest) be used by Te Papa for the purpose of museum display". Megan Tamati-Quennell explains that the majority of Māori staff at Te Papa were also uncomfortable with exhibiting Keku. "If it was a Māori’s human remains you wouldn’t show it so why show an Egyptian one? It's culturally inappropriate for anyone to show someone’s grandmother on display, you don’t need it; you could have just had the sarcophagus." Mark Solomon was also on the Te Papa Board at this time and recalls that the Keku exhibition was "a huge issue". He recalls the incident: 
Seddon fully organised it and jacked everything up and then came and told the board. And when he presented to the board, I said to them 'You can't'. He said 'Why not?' and I said 'Well, look at your own policies. The policy of Te Papa is that we will not display human remains. That's your own policy, you can't do this'. It then developed into a huge war but not at the board level (who agreed with me), but ultimately we were told we had to do it by the Prime Minister. She intervened... I found that although the board then was all Pākēha, they tried their best.

Ironically, Tamati-Quennell recalls that years previously Te Papa "had actually consulted with Ngāi Tahu about iwi repatriation and Karanga Aotearoa because it was one of the only iwi that had a written policy about human remains that Gerald O'Regan had put in place and was a policy that Te Rūnanga had adopted". Eventually, Ngāi Tahu led by the ISG insisted on a meeting with the Board of Te Papa to convey their concern and point out what they saw as Te Papa's hypocrisy (ISG minutes 11 September 2006).

Carolyn Roberts-Thompson remembers how ISG chairman Rakiihia Tau explained to her that "apples will speak with apples, and oranges will speak with oranges". He relayed, "'Oh no, we don't want to talk to you Mr Chief Executive Officer we want to talk to the Chairman of the board... you're an orange, you're not an apple'. That was their philosophy and their approach." Te Papa, however, was already committed to exhibit Egypt: Beyond the Tomb and while the Te Papa Board did sympathise and agree with Ngāi Tahu's objection, high-ranking political intervention meant that the exhibition with the mummy of Keku went ahead at Te Papa. It was finally agreed that Keku would be treated with the utmost care and respect which resulted in a separate space within the exhibition for the mummy of Keku, and water bowls at the exits of the exhibition in accordance to Māori tikanga where water is used to whakanoa (neutralise tapu). The National Museum of Antiquities, Leiden, the Netherlands, which toured Egypt: Beyond the Tomb was "impressed by Te Papa's approach to displaying the mummy and have since changed their practice and procedures". Presenting the mummy of Keku with dignity and respect as a person was also a "learning process for Te Papa, with beneficial consequences for other museums" (Te Papa 2007, 46).

Tensions over the mummy of Keku in this exhibition brought out issues around governance and the organisational hierarchy at Te Papa, which was compounded by the fact that Te Papa was 
looking to appoint a new Kaihautu. Ngāi Tahu argued that if the Chief Executive and Kaihautu were meant to share responsibility for the strategic leadership of Te Papa, then the appointment of a new Kaihautu should be made by the Te Papa Board, not the Chief Executive, and that they should both report to the Board rather than the Kaihautu reporting to the Chief Executive (McCarthy 2011). Megan Tamati-Quennell recalls Ngāi Tahu's intervention:

Ngāi Tahu pushed at that point from a governance level for the CEO and Kaihautu to have an equal standing... and that had nothing to do with the iwi exhibition but came out of that by being the iwi in residence at Te Papa. Also our iwi kaumatua had to deal with all that stuff that was going on with Keku, and Ngāi Tahu being a strong Treaty partner.

Piri Sciascia explains that the ISG were concerned that if Te Papa was the bicultural institution that it claimed to be, then the status of the Kaihautu needed to be equal to the Chief Executive. He recounts what happened:

We refused to accept that it be Seddon's appointment alone. They may have left it there because of legislation, but we said 'You need to work beyond that', so John Judge (Chair of the Te Papa Board) came onto the panel and became part of the selection process and I think Ngāi Tahu was in there as part of the process, perhaps through Kukupa. And when it came to review and reporting time it no longer became only the Chief Executive, the Board deals with. It had to have a special time just with Michelle (newly appointed as Kaihautu) and then time with both of them together as well. That's what we were told and understood. Ngāi Tahu was quite adamant that there needed to be changes about that because it was about the mana. And thank goodness that was in place because immediately after you had Seddon's death and Michelle was in charge and she could be, and the Board could have confidence in her because the Chairman had had reporting sessions with Michelle alone.

Changes had clearly occurred internally as a result of Ngāi Tahu's presence. This was evident when comparing Te Papa’s 2006-07 Annual Report to the 2007-08 Annual Report. The 2006-07 report of the organisational structure clearly has the Kaihautu beneath the Chief Executive (see appendix 3). It also only refers to the Board and Chief Executive relationship, as follows, "The Board reviews the performance of the Chief Executive annually against agreed performance targets and priorities" (Te Papa 2007, 15). However, in the next Annual Report, the Kaihautu is equal with the Chief Executive in the governance structure (see appendix 4). The report reads "The Board Chair addresses the performance of the Chief Executive and the Kaihautu annually against agreed performance targets and priorities" (Te Papa 2008, 18). Carolyn RobertsThompson expressed her gratitude to Ngāi Tahu who had the nous and conviction to talk 
directly tothe Board. "If Ngāi Tahu didn't go to the Board and have the courage to make that statement then people would still not try and advocate that position", she stated, "It was the right time to do it, and it won't be forgotten... thank you, thank you, thank you."

\section{Kaitiakitanga}

The Mō Tãtou exhibition enabled Ngai Tahu to renew the practice of kaitiakitanga responsibility and stewardship over their taonga. Kukupa Tirikatene explains how "it created a new embrace of Ngāi Tahu's taonga. We were reconnected... the taonga have done their work; they have brought the people together". Vicki Ratana also commented about the role of taonga and that "it created those discussions back amongst the hapū and whānau about their taonga; which taonga they'd bring for the Papatipu Rūnanga wall, and which stories". Puamiria ParataGoodall noted that when the exhibition toured in the South Island, an increasing number of local iwi members were able to participate by taking on the responsibility of kaitiaki. Parata-Goodall felt that this was a big learning curve for some Ngāi Tahu people who had not yet experienced this guardianship role with taonga. She describes the effect of contact with taonga and people:

Working with touring the exhibition we saw the opportunity for our whānau to truly engage with our taonga and what that means to us as an iwi. There was a lot of work about manaaki... they're not just things; they're your tipuna so you keep this place warm. Yes this is a museum but in this context our tipuna are here, koira whakamahana te whare and manaaki your taonga, your tipuna. It also brought a personal presence, that living face to the exhibition, he kanohi kitea.

Piri Sciascia commented that the "dynamic embrace and engagement with taonga Māori occurred with Mō Tātou, because you had these powerful old pieces, nga pou and then these other contemporary pieces". He continued by explaining that:

Te Papa has that Mana Taonga concept, and Ngāi Tahu embraced that but I think we did more because of the addition of new taonga, particularly when it went home, so you had kakahu, pounamu and whakairo and the tipuna photos, and the exhibition gave life to new taonga and pieces that were created for the exhibition or had been created and were deemed to have high worth and value and should be given place to support and be exhibited in Mō Tātou. There was Mō Tātou: mo nga uri a muri ake nei and then you had mo nga taonga a muri ake nei.

In profiling what kaitiakitanga means to Ngāi Tahu, I have chosen two particular taonga from the research which provide a useful insight into the wonder of taonga and kaitiakitanga. First, the large 
pounamu boulder named 'Te Māori'. This was found in 1986 and became known as the mauri stone for the Te Mãori exhibition when it returned from America and travelled throughout the country with the rebranded exhibition name Te Māori: Te Hokinga Mai. For the past twenty years it has been at the Southland Museum until it was decided that it be included as a touchstone for $M \bar{o}$ Tătou and was considered a central piece because of its connection with the many other taonga from other iwi when it was displayed with the Te Māori exhibition. The 'Te Māori' stone had the prominent position at the very front of the exhibition, as an invitation to visitors coming into the exhibition space (see appendix 7, 12). It was a touchstone where people were able to rub the pounamu and feel their connection to the exhibition. Its inclusion in the Mó Tâtou exhibition added another rich layer of meaning and kōrero or narrative to the 'Te Māori' pounamu and in effect enhanced its mana. Piri Sciascia explains that Ngāi Tahu's kaitiakitanga of the 'Te Māori' stone was renewed and also given a new prominence at the final closing ceremony of Mō Tâtou. He describes the process:

It became the symbol of giving the mauri [life principle] back to the people. By lifting that stone up at the end of the karakia and taking it outside and having our final karakia outside the exhibition with our elders leading and our people gathered. The Te Māori stone symbolised the end of the exhibition and handing the mauri back to the people which is what the Otakou rūnanga people wanted to achieve. So you had some important tikanga moments that developed from their idea.

The second taonga was a greenstone mere which had been deposited with the Southland Museum by the Topi Whānau of Awarua, Bluff (see appendix 13). Before the Mō Tãtou exhibition it was known as the Topi mere. However, after discussions between the ISG and the Topi whanau, it was bestowed with the name 'Te Kaipatuki' so that it was displayed with a name in the exhibition. Usually when a taonga is named, this is perhaps the first layer of narrative it inherits. The name can be an acknowledgement of who is giving or made the taonga, who is receiving the taonga, an ancestor, a descendant, a historical occasion, or an important current event or a future aspiration. This in itself was a reclamation of cultural knowledge by the Topi whānau. The mere pounamu was personally delivered to Te Papa by Peter Topi Jnr and his mother Joyce Topi in the months before the opening of Mō Tātou in 2006 (Topi pers. comm. 20 June 2011). Tragically, however, in May 2006 three generations of the Topi family died when the Bluff trawler Kotuku sank in the Foveaux Strait after returning from mutton-birding on Kaihuka Island (The Southland Times 15 May 2006). Their funerals attracted over 3000 mourners including ISG members and 
Te Papa staff who travelled to Bluff, after having just received their family mere pounamu. Meanwhile, back in Wellington, kawakawa leaves were placed with 'Te Kaipatuki' by Te Papa Collections Manager Moana Parata, acknowledging the connection to the whanau pani (grieving family) as if the taonga itself were grieving. Te Papa waited to see if the Topi whānau would ask for their taonga to be returned and perhaps even pulled out of the exhibition; however, the family decided to leave it there. When Mō Tãtou opened later that year, Megan Tamati-Quennell recalls that:

The most moving moment for me was when Peter Topi wanted to go in to the exhibition and see his mere that they had given to the exhibition and just cried because it was the last time he had seen his father and sister. It was just awful but also the most moving thing of the whole day that amidst all that ceremony there was something very human and intimate. He asked 'Can you take me in before breakfast to see my taonga' and he had a big tangi (expression of grief) and to me that was the most tangible thing of people's connection to taonga. That mere pounamu not only has the old history and whakapapa associated with it, but also now that recent history of his own family... taonga carry those things.

Finally, after the exhibition closed in April 2011, 'Te Kaipatuki' was returned, and members of the ISG and curator Megan Tamati-Quennell contacted the family, mindful that it could be a sensitive time. She recalls that "I spoke with Peter Topi to ensure that he knew their taonga was coming back to Southland Museum and he could be there if he wanted to be or if that day worked with him, and give them the opportunity to be involved, to have karakia."

The two examples of the 'Te Māori' stone the Topi greenstone mere 'Te Kaipatuki' provide an intriguing insight to the agency of taonga as a catalyst for new or renewed relationships amongst iwi, hapū and whānau. These relationships are fluid and transcend time. The second theme covered in this chapter, conveys a powerful trilogy of Māori concepts that are central to Māori belief and being. These concepts are rangatiratanga (chiefly authority), mana (prestige) and kaitiakitanga (guardianship), which from a Māori perspective will be fundamental to any relationship iwi will form with museums.

\section{Ngāi Tahutanga: Culture and Identity}

The third and final theme that emerged from the data as a result of using an inductive method for analysing the interviews concerned what Mō Tãtou meant to Ngāi Tahu. How did the exhibition contribute to the cultural identity and aspirations of the iwi? Ngāi Tahu have been very active in identifying cultural values and aspirations in a self-conscious effort to rebuild and revitalise their 
cultural knowledge and practices as illustrated in the Ngāi Tahu 2025 vision. The Ngāi Tahu 2025 publication acknowledged that "ongoing events and celebrations enhance Ngāi Tahu culture and identity". It went on to list key issues and assumptions, as well as articulating what the iwi would like to achieve regarding "to tatou Ngāi Tahutanga - culture and identity". It stated that one of the key issues for Ngāi Tahu culture and identity is that "for many Ngāi Tahu, engaging in our culture happens in our leisure time. We can create fun, enriching and attractive ways for our people to participate in, and strengthen, their Ngāi Tahutanga" (Ngāi Tahu 2001, 17). Interviewees acknowledged the significance of $M \bar{o}$ Tãtou in advancing their cultural redevelopment. They refer to the success of bringing the exhibition 'home' to tour the South Island and expressed their excitement about what the future holds. Jane Davis declares that she believes Mō Tātou "was worth every cent and Ngāi Tahu will reap the benefit of it for years to come. I just look at the young people; they're all so enthusiastic and proud of who they are and want to be involved."

\section{Reclaiming knowledge}

It becomes clear through analysing the interviews that interviewees felt that Mó Tâtou was not only a representation of the cultural landscape of Ngai Tāhu but also the iwi's efforts to revitalise the culture in that the exhibition itself was clearly an active medium in the growing of cultural awareness and identity for Ngāi Tahu. Tamati-Quennell commented, "Ngai Tahu are very progressive in that way. They're also kind of in the phase of reinventing themselves, so it's about reclaiming knowledge and moving forward. For me it's important that that cultural dynamic is there and it's not just the museum aspects of ourselves." Jane Davis recalls that the exhibition has:

Helped reawaken our culture. I still think we're in recovery mode in lots of ways... there's still a lot of growing and learning within our culture, but I think Mō Tātou has been a good catalyst. On opening day we had 2000 people; it was amazing. It was like the ancestors called and the people answered and they came. It was a very blessed day.

Mō Tãtou is also credited as being invaluable to the iwi in terms of exhibiting Ngāi Tahu's preclaim history and cultural practices. Parata-Goodall recalls visiting the display at the museum in saying that: 
Each of those old taonga have a story to be told, that is pre-claim korero... this is my whakapapa; this is my tipuna, my tipuna made this. It opens all those conversations that I don't know we would have had because for this generation in particular, our living memory is about the claim. So that's what we know. If we don't have those tangible reminders then you just get stuck in that space, you don't realise there's a whole layer of stuff that led to it and is important if not more important than what is in our living memory.

Parata-Goodall goes on to illustrate how the exhibition has enhanced Ngāi Tahu's identity. "We are retelling and hearing these stories again, we are learning about ourselves and our identity." Mason Durie suggests that a "Māori self-determination is a shallow goal if a Māori identity is not part of the equation" (2001, 82).

Ngai Tahu is very aware of the vast challenge it faces to rebuild and revitalise its culture. As Mark Solomon acknowledges, "we've got a lot of catch-up to do. The saddest thing is that we've lost so much". However, he is quick to add that "there are more and more young people that are culturally hungry". Solomon is satisfied that Ngāi Tahu took full advantage of the Mō Tātou exhibition to enhance the iwi’s culture and identity. "It’s amazing watching our people", he said. "You could see the excitement and the pride. You saw the pride in Ngāi Tahu". For identitymaking to be meaningful, it must be optimistic and positive. Ngāi Tahu kaumātua Sir Tipene O’Regan argues, "There is no way you can build identity on a negative basis" (cited in O’Regan 2001, 169).

\section{Mō Tātou: Te Hokinga Mai - Touring the exhibition}

Touring the exhibition throughout the South Island within the tribal boundaries of Ngāi Tahu was considered by interviewees an absolute success and the most significant factor that enabled Ngāi Tahu to connect with the exhibition on a local level. In Ngāi Tahu’s 2010 Annual Report, Chief Executive Officer Anake Goodall commented that "having this amazing collection of our taonga in our own regional museums and accessible to our own whānau and local communities is at least as significant as our very successful presence at Te Papa itself" (Ngāi Tahu 2010, 7). Tamati-Quennell felt that for her there was a lot gained by taking the exhibition on tour, especially down south. She elaborates here on this point:

Te Papa toured it as a package which meant they could do their own support show or whatever they wanted... they can define it as they want to define it and pull in their expertise, and they all did. In Canterbury they had close to 200 taonga that had never 
been seen from out of their collection and they had never put together before. They almost did a whole show in response to Mō Tātou which was extraordinary and put together an events programme that drew on local knowledge to talk about mahinga kai practices and they also had guides that they trained up.

The touring exhibition provided another level for iwi members to explore and express their Ngāi Tahutanga. Puamiria Parata-Goodall explains that people were engaging not only with their identity as Ngāi Tahu but they were engaging with their identity as hapū and as rūnanga. She observed that they were "recognising I'm not just Tahu, I'm Irakehu or Mako or I’m Kuri, and that not all Tahus are the same because we come from different strands and we understand things at different levels".

The exhibition also provided an opportunity for Ngāi Tahu members who were at the initial stage of identifying as Ngāi Tahu. Vicki Ratana commented that "Mō Tātou was a soft and easy access point for whanau who aren't quite connected, so they could participate and identify and begin their journey in an open, friendly forum". Puamiria Parata-Goodall also made reference to the touring exhibition being a "soft entry point" for those iwi members who are in the early stages of learning about their Ngāi Tahutanga. Here she talks at length about this point:

People would come to Mō Tâtou. They'd say 'I’ve come because I'm Ngāi Tahu but I don't know anything about it', so we would take them around the exhibition. There were those nice connection points because it wasn't a marae and when you think about it for us that's often scary and we know that space, so what about those that have never engaged with a marae or may not even know which marae is theirs. So the exhibition was a real nice soft entry point for them and they would keep coming back every workshop and even if it was the same workshop as last month, they kept coming back because that was their one connection to their Ngāi Tahutanga. They'd learnt another little piece of information, a piece of the jigsaw.

This idea of repatriating cultural knowledge is also covered in the literature by Laura Peers and Alsion Brown who state that artefacts "prompt the re-learning of forgotten, or not common, knowledge and skills". They continue by saying objects "provide opportunities to piece together fragmented historical narratives and are material evidence of cultural identity and historical struggle" (2003, 6).

There was also a great deal of public programming around the touring of Mō Tātou. This not only attracted Ngāi Tahu iwi members but was also an opportunity for Ngāi Tahu to 
communicate to the wider public about what is important to Ngai Tahu - their identity, priorities and aspirations. Jane Davis recalled that when the exhibition went to Southland:

The community at large came and that was a real plus for us, that the wider community came and embraced it as well so I think for our culture it's probably been something that money can’t buy. Because it's always costly and it was costly for Ngāi Tahu but I think if we look at it long term it was very well worthwhile.

There is no doubt the Mō Tātou: Te Hokinga Mai was revolutionary for Te Papa’s IEP, in returning and touring the exhibition back within the tribal boundaries of the iwi. It provided a greater opportunity for iwi members to engage and connect with their taonga rather than being staged at Te Papa for exhibition's sake. The touring exhibition visited the three major cities throughout the South Island. In the recent Karaka magazine, curator of visual arts at the Southland Museum Irene Mura Schroder (Ngāti Māmoe, Ngāi Tahu) commented that "The central thing for me was the photographs of tupuna." She added that, "It was such a connecting point. People would look at the images, they would find their families. The whole things had a spiritual meaning, it was beautiful" (Te Karaka 2011, 46). Jane Davis also conveyed her delight in Ngāi Tahu families at the museum. She exclaimed, "Seeing our people walking in places like this with their children, it’s wonderful! And appreciating what they are seeing, our children are growing up with this now. I mean I can’t remember being in a museum when I was a child; museums were always dead and dusty places." In reflecting on the Mō Tātou experience for Ngāi Tahu, Mark Solomon asked, "What has it done? It has taught us about ourselves. It has taught the rest of the nation about us. It is the biggest expression of Ngāi Tahu; it has been a beautiful journey" (Te Karaka 2011, 47).

\section{Where to from here? What next?}

Ngāi Tahu is mindful of further capitalising on Mō Tātou and continuing with the momentum that the exhibition has provided as part of accelerating attempts to rebuild and revitalise its cultural identity. Megan Tamati-Quennell discussed this point:

For me what happens now is really important too. What is it you want to do now? Do you want our people working with taonga in museums? What are your cultural aspirations now post-Mō Tâtou? What do you want to build on? And we're having a cultural summit, so I think it's really important that we're there and ask out of that 'What did you gain? What next?' 
Unfortunately, due to the second destructive 6.3 earthquake in Christchurch in February this year, which followed a massive 7.1 magnitude earthquake in September 2010, Ngāi Tahu postponed the 2011 Cultural Summit until further notice. However, Ngāi Tahu 2025 is a living vision and despite the very challenging environment, there is still impetus for including plans for a Ngāi Tahu publication that captures the core themes and vision of the exhibition, a further statement from Mō Tātou of Ngāi Tahutanga. Piri Sciascia hopes that the publication differs from a museum-type catalogue that tells you museum information about each object and its dimensions, but rather is a publication centred on Matauranga Māori - the cultural knowledge of the taonga, tikanga and karakia. Sciascia explains that "the publication would capture the cultural knowledge associated with the exhibition and celebrate that." Ngāi Tahu also continues to administer the Ngai Tāhu Fund. In 2010 alone they received 123 applications, approved 84 applications and allocated \$890,329 (Te Rūnanga website 2011). Jane Davis observed that increasingly Ngāi Tahu iwi members' cultural aspirations are being connected with the marae. She comments that, "What I've noticed being chair of the Ngāi Tahu Fund is people are focused on getting themselves established with marae. People want to return to the marae situation... I suppose that's where it will grow out of; people are focused with marae and bringing back the culture through that."

Ngāi Tahu acknowledges their identity is not some type of containable item that can be frozen in time. Like any identity, it must be able to negotiate changes and adapt to the social, political and economic realities (Nederveen-Pietersee in Corsane 2005). Tamati-Quennell exclaims that, "If we're sophisticated enough as a culture, we should be able to value both those historical things that make us who we are, as well as the contemporary moments that push us somewhere else." The process of constructing meaning, Hooper-Greenhill explains "is like holding a conversation. No interpretation is ever fully completed. There is always more to say and what is said may always be changed - meaning is never static" (cited in Carbonell 2004, 566).

\section{Condusion}

In reflecting back through this chapter, it is clear that an inductive analysis has provided a rich perspective on interview data gathered in this research; this process enables exploration and 
discovery without pre-existing expectations (Patton 1990). The findings confirmed that $M \bar{o}$ Tātou benefited from a robust partnership between Te Papa and Ngāi Tahu who were both well resourced and solutions-focused in producing a high-quality exhibition. Ngāi Tahu also grew in confidence in expressing the tribe’s mana, kaitiakitanga and tino rangatiratanga over its taonga and tikanga. Also, evidence shows that Mō Tātou was used as an exemplary tool by Ngāi Tahu to advance the tribe's redevelopment of their cultural heritage and identity. The qualitative data in this chapter supports the research presented in chapter two on the iwi survey. Although the themes that emerged from both methods were similar, the research in this chapter both enriches and complicates theories of the museum and source community relationship, as illustrated through examining the candid responses from interviews. There is no straight linear relationship between the museum and source community. Rather, as examined by the Te Papa-Ngāi Tahu partnership, there are myriad relationships occurring simultaneously within the source communities themselves, between the source community and the objects, between the exhibition display and the interpretation, the museum staff, both collection managers and curatorial staff, and ultimately a relationship with the museum's governance structure. This illustrates the complex nature of the museum-source community relationship, similar to that of a spider-web, all connected and intertwined.

Finally, the research in this chapter also extends the growing literature critiquing Māori agency within museums. Just as 100 years ago master-carver, Neke Kapua (Ngāi Tarāwhai) declared during the 1906 International Exhibition in Christchurch, "Our works of ancient time have been brought here, so that the peoples of the earth may know that the Māori is still living" (cited in McCarthy 2011, 5); so Mō Tātou is too a statement of survival - of the tenacious efforts of Ngāi Tahu. Both examples illustrate the rich exchange and collaboration between Māori and museums in the display and interpretation of their taonga and cultural heritage. I now move on in the following concluding chapter of this dissertation to provide a brief summary of the study and its key findings. I will then assess the relevance of this research for museum studies, before making recommendations for partnerships between museums and Māori, and future iwi exhibitions at Te Papa. 


\section{Condusion}

The focus of this dissertation was the dynamic relationship between museums and Māori. The Ngāi Tahu Whānui iwi exhibition Mō Tãtou provided a case study to explore current museum practice at Te Papa and other New Zealand museums, and how iwi exhibitions play a role in the resurgence of iwi identity and tribal efforts to define their cultural heritage. The research question specifically asked how has Te Papa managed and developed a relationship with a tribe through the process of developing an exhibition and how have Ngāi Tahu in turn used the exhibition to enhance their tribal identity and advance their cultural heritage aspirations? By combining both qualitative and quantitative methodologies endorsed by a kaupapa Māori framework, this dissertation makes a contribution to scholarship through original research into this under-examined topic, and providing a unique inside and outside perspective on the topic that is from both the museum point of view and importantly the view of Ngāi Tahu itself. It also provides an up-to-date case study of a collaborative exhibition to the academic literature and a critical analysis of current museum practice in a former settler colony grappling with its colonial legacy, as well as exploring ongoing issues which may assist future policy development in museums throughout Aotearoa New Zealand.

From the onset of this research, it was not my intention to give a positive appraisal of Te Papa's IEP to counter the numerous academic critiques of Te Papa's bicultural commitment (Henare 2005, Message 2006, Tapsell 2004, Royal 2007, O’Regan 1996, Tamarapa1994). However, on the basis of the evidence gathered here, I believe the Mō Tãtou exhibition has made a valuable contribution to the evolving relationship between museums and Māori and provides an encouraging example to indigenous people and source communities internationally. It is possible to cooperate on an exhibition; partnership and collaboration are feasible, and the results can be beneficial for both sides.

As shown in the survey results in chapter two, a compelling $90 \%$ of respondents visited the $M \bar{o}$ Tâtou exhibition. The public programming of the exhibition was also an astounding success with 
practically everyone who visited the exhibition also attending a scheduled event associated with the exhibition (89\% of respondents). The primary motivation to visit Mō Tätou was "to learn and reconnect" to their Ngāi Tahutanga. The exhibition without doubt was a catalyst in generating new interest among Ngāi Tahu in their tribal identity and their cultural heritage aspirations. An astounding $84 \%$ of respondents either strongly agreed or agreed that the Mō Tãtou exhibition enhanced their Ngāi Tahu identity. While $83 \%$ of respondents agreed that the exhibition generated new cultural aspirations, these aspirations were largely centred on a desire to learn Ngāi Tahu identity, including learning te reo and whakapapa, as well as artists inspired to create new artworks.

The data in chapter three revealed the complexity of establishing and maintaining relationships between museums and source communities. Inductive analysis explored and profiled some of the challenges that are faced during the development of iwi exhibitions; these included marketing decisions, assumptions about design and graphics, loaning of objects and obtaining sign-off. The research also illustrated that museums still have expertise and practices that can benefit and are of value to the iwi or the source community in managing their material culture. The dynamisms of Māori customary concepts of rangatiratanga, mana and kaitiakitanga were also examined in terms of the power-knowledge relationships and the politics of display within a tribal context. Finally, the agency of the exhibition itself was analysed through the production of meaning and the construction of a Ngāi Tahu identity as measured in survey and interview responses. The idea of the exhibition as a 'soft entry point' is also useful when considering those from the source community who are only beginning their journey of self discovery and starting to express what it means to be Ngāi Tahu.

Ultimately, the most significant contribution of this dissertation, however, is that it reveals indigenous voices and indigenous responses to current museum practice. In contrast to much literature which describes museums rather than source communities, the originality of this study is that it has captured a Ngāi Tahu perspective in evaluating how the Mō Tãtou exhibition has assisted the people of Ngāi Tahu in their efforts to enrich their cultural heritage and enhance their cultural identity. While it is essential for an indigenous voice to be present in the development of an exhibition that presents its cultural heritage, its role should not be assumed as a passive subject. It is also important to hear that indigenous perspective in the evaluation of the 
exhibition and ask not only how the exhibition has helped the museum, but what has it done for the community from which it originated. Mō Tâtou also provides an example of how iwi can use the museum and exhibitions as a forum to tell their stories to the wider public and indeed the world thus by-passing mainstream media. Tamati-Quennell pointed out, "I think the exhibition at Te Papa made people outside of Ngāi Tahu realise that the tribe is not just an economic force, which is what we are often seen as through the settlement and investments; but that we are also a cultural force". Ngāi Tahu viewed the IEP as an opportunity to create identifiable and credible ways for its iwi members to access Ngāi Tahu culture in both traditional and modern forms. Hence the Mō Tâtou exhibition was not only a reflection of Ngāi Tahu, but an extension of its cultural identity.

Mō Tãtou, however, does not attempt to be the conclusive definition of Ngāi Tahu's material heritage and cultural identity. Rather Tamati-Quennell describes Mō Tātou as something which:

...captures a moment in time; it's our perspective of what our history was at that moment in time. If you did that exhibition again based on the same principles it might be really different because time shifts on and people's view of things shifts. The exhibition doesn't try to cover everything - why would you do that? Why put up a full stop and close it off (pers. comm. Oct. 26, 2006).

Ngai Tahu has used Mō Tâtou as a springboard to regenerate its cultural aspirations and tribal identity. The exhibition contributes to a wider strategic cultural vision, including hosting regular cultural summits for the iwi, the allocation of funding from the Ngāi Tahu Fund to its people and the recently opened Ngāi Tahu Rock Art Centre Te Ana in Timaru.

So what can be learnt from Mō Tâtou? I propose the following three recommendations for partnerships between museums and Māori, and future iwi exhibitions at Te Papa. First, that Te Papa continues to have an open and flexible approach to establishing and maintaining Māori and iwi relationships. Initially I was sceptical that Te Papa did not have a formal policy on the IEP, and felt this could be seen as a lack of leadership in articulating and expressing a commitment to the initiative. However, after further analysis and deeper consideration, it became clearer that in regard to iwi exhibitions and partnerships, one size does not fit all. A prescriptive policy could limit potential outcomes that derive from the IEP as well as confine the voice of iwi in the process. Iwi partnerships with museums are never a simple 'tick the box' exercise. As each iwi is different and each generation redefines its relationship with taonga and museums, every iwi 
partnership will differ and evolve. By Ngāi Tahu asserting their voice within the exhibition in its entirety, the tribe has questioned the extent to which Te Papa allows iwi to have a genuine voice and pursue their own agenda within the existing institutional structure. Much to Te Papa's credit, they acknowledged and responded to this challenge. As discussed in the literature review, dialogue theorist William Isaacs provides a useful narrative to describe Te Papa's response; he states that "dialogue implies that you no longer take your own position as final. You relax your grip on certainty and listen to the possibilities that result simply from being in a relationship with others" (1999, 33). In its Ko Aotearoa Tenei report, the Waitangi Tribunal commented that "while Te Papa has no single, formal partnership table with Māori, it has a range of provisions that collectively meet the partnership requirements of the Treaty" $(2011,505)$. If iwi are required to fit within a museum framework that narrows their voice, then this will only give impetus to those iwi that are working towards establishing their own tribal cultural centres. Museums engage with current Māori aspirations or risk becoming irrelevant. If iwi pursue their vision of tribal cultural centres to interpret and display their cultural heritage, then museums run the risk of becoming redundant and could ultimately find themselves on the outside, which in itself is not an inherently bad option. The shift in this relationship is expressed by McCarthy who states, "from asking how museums can meet Māori needs, the question now becomes: How can museums support Māori aspirations?" (2011, 246).

The second recommendation is for Te Papa to consider adopting the term, 'kaitiaki communities' when applying the Mana Taonga principle. This term extends Peers and Brown's theory of source communities and applies it within a matauranga Māori framework, similar to community of interest but with Māori dimensions of kaitiakitanga including spiritual stewardship (2003). 'Kaitiaki communities’ is a phrase that has been used to describe New Zealand's native biodiversity (Waitangi Tribunal 2011); however, by placing it within the context of the museum and cultural sector, kaitiaki communities acknowledge that taonga signify both value and relationship (Smith 2011). In effect, Te Papa already acknowledges kaitiaki communities without using this term by recognising the "spiritual and cultural connections of taonga with their people through whakapapa of: 1) the creator of specific taonga; 2) the ancestors after whom the taonga is named; and 3) the whanau, hapū or iwi to whom the taonga is an heirloom" (Te Papa 1992, n.p.). This illustrates the complexity of kaitiaki communities; in that an individual taonga could possibly have multiple kaitiaki communities. Kaitiaki communities have both a role and 
responsibility in the care and management of their taonga, as ultimately their interest is to protect its cultural and spiritual integrity. Kaitiaki communities are long-term stakeholders. Their ongoing cultural and spiritual guardianship of taonga is intergenerational - it acknowledges past relationships, the people in the present and the future generations.

Thirdly, I believe museums need to be encouraged to enter power-sharing partnerships with Māori instead of hoping Māori aspirations will be satisfied with policies that effectively absorb Māori into mainstream museum ideologies. The Māori-museum relationship could advance further by museums seeing the benefits of tino rangatiratanga by Māori within the museum. Tino rangatiratanga does not need to be feared by museums, rather it enables iwi to participate fully and engage as a true Treaty partner. This approach takes courage on behalf of the museum, as being open to tino rangatiratanga could leave the organisation somewhat vulnerable as decisionmaking is shared. Iwi exhibitions and partnerships, however, are built on a leading principle of good faith and, as Ngāi Tahu and Te Papa demonstrated in this research, this resulted in producing arguably the most successful iwi exhibition at Te Papa. Furthermore, the touring exhibition Mō Tātou: Te Hokinga Mai is an innovative demonstration of what is possible when an exchange of power-sharing and decision-making occurs between museums and Māori. The touring exhibition, which resulted from a joint partnership between Ngāi Tahu and Te Papa, was mutually beneficial for both partners. For Ngāi Tahu, it enabled a reconnection with taonga and cultural identity, and for Te Papa it helped them meet their objective to successfully collaborate with other New Zealand museums, as stated in their current Annual Report.

I believe Ngāi Tahu also provides an example to Māori of how iwi can engage with museums. A contributing factor to this successful partnership has been how the iwi entered into the relationship as a Treaty partner. The national museum is an extension of the Crown, and Ngāi Tahu therefore regarded their partnership as a Treaty relationship rather than merely a partnership to co-curate an iwi exhibition. As a post-settlement iwi, that is to say a tribe that has settled their Treaty claim, Ngāi Tahu had the expertise and negotiation experience to balance its statement of tino rangatiratanga within a bicultural organisation. This required the iwi to be fluid in its approach. At times this was resolved through their tikanga, where cultural values and beliefs were not negotiable and they vigorously asserted their mana within the relationship, and at other times being progressive and solutions-focused within the partnership. Kaumatua Kukupa 
Tirikatene explains that "like any museum there’s pulls and pushes and currents". He continues by saying, "but the steering committee made sure we're there to do a job, and that's what we'll do regardless of how other iwi have done things". The museum is a natural setting where taonga Māori and Treaty relationships merge, evolve and are tested.

This dissertation ends with an image which shows how for my tribe this event was more than simply a museum exhibition but a means of closing a painful period of our past, of bringing the story full circle. Te Hapa o Niu Tireni is a Ngāi Tahu meeting house in Temuka, South Canterbury. Its name means ‘the grievances of New Zealand' or 'the broken promise', in reference to the long-pursued Treaty claim of Ngāi Tahu, Te Kereme. If Te Hapa o Niu Tireni is a symbol of Ngāi Tahu's past Treaty grievance, then Mō Tätou is a proclamation of our cultural renaissance and future aspirations, as stated in the exhibition themes: toitu te iwi, toitu te rangatiratanga, toitu te ao turoa, toitu te pae tawhiti! 
Appendix 1: Timeline

2006 July Opening of the Mō Tātou: Ngai Tahu Whanui exhibition at Te Papa, Wellington

2006 December

2007 March

2008 February

2009 July

2009 August

2009 October

2010 February

2010 July

2010 December

2011 April

2011 July
Egypt: Beyond the Tomb opens at Te Papa

Kaihautu Te Taru White resigns from Te Papa

Michelle Hippolite appointed Kaihautu at Te Papa

Chief Executive Dr. Sneddon Bennington dies unexpectedly

Mō Tātou: Ngai Tahu Whanui exhibition closes at Te Papa

Kura Pounamu exhibition opens at Te Papa

Mō Tātou: Te Hokinga Mai and Mo Ka Uri open at Canterbury Museum, Christchurch

Mō Tātou: Te Hokinga Mai and Mo Nga Uri: Ngai Tahu Contemporary Art from Murihiku open at Southland Museum, Invercargill

Mō Tātou: Te Hokinga Mai and Aukaha Kia Kaha: Strengthen the Bindings open at Otago Museum, Dunedin

Final closing of the Mō Tâtou: Ngai Tahu Whanui exhibition at Otago Museum, Dunedin

Kura Pounamu exhibition closes at Te Papa 


\section{Appendix 2: Te Papa's Operating Framework - Annual Report 2009/10}

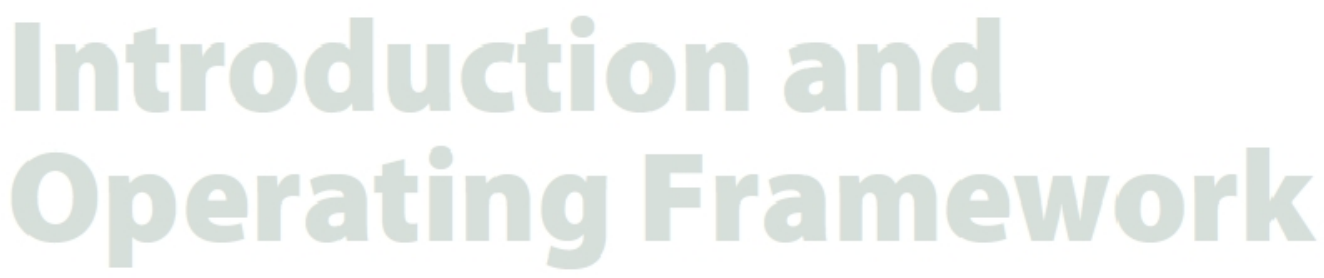

The Museum of New Zealand Te Papa Tongarewa is a forum for the nation to present, explore, and preserve the heritage of its cultures and knowledge of the natural environment in order to better understand and treasure the past, enrich the present, and meet the challenges of the future.

\section{Concept}

Te Papa's concept is founded on:

Papatūānuku - the earth on which

Tangata Whenua - those who belong to the land by right of first discovery

Tangata Tiriti - those who belong to the land by right of the Treaty of Waitangi

The concept encompasses:

- the principle of unified collections

- the bicultural partnership between Tangata Whenua and Tangata Tiriti

- the narratives of culture and place

- a multidisciplinary approach to delivering a national museum for diverse audiences

v the idea of forum.

\section{Corporate Principles}

Within the concept, Te Papa has adopted the following corporate principles that form part of the criteria for decision-making and provide a framework for assessing Te Papa's performance:

Te Papa is a Waharoa

Te Papa is a waharoa (gateway) to New Zealand's natural and cultural heritage and provides a forum in which to explore and reflect on our national identity.

He Waharoa a Te Papa Tongarewa Ko Te Papa Tongarewa te waharoa ki ngà tikanga tuku iho me te taiao o Niu Tîreni, he wāhi hei wetewete, hei titiro arorau ki tō tătou tuakiri.

Te Papa is Bicultural

Te Papa values and reflects the cultural heritage and diversity of Tangata Whenua and Tangata Tiriti.

He Tikanga Rua a Te Papa Tongarewa Ewāriu ana, e whakaata ana a Te Papa Tongarewa i ngã tikanga tuku iho me ngā rerenga kētanga o te Tangata Whenua me te Tangata Tiriti.
Te Papa acknowledges Mana Tāonga Te Papa recognises the role of communities in enhancing the care and understanding of collections and tãonga.

E Tautoko Ana a Te Papa Tongarewa i te Mana Tãonga

Kei tẽnã nohonga tãngata ă rẵtou tikanga tiaki me ă ratou māramatanga ki ã rătou kohinga me ã rătou tãonga.

Te Papa speaks with authority All of Te Papa's activities are underpinned by scholarship drawing on systems of knowledge and understanding, including mātauranga Mãori.

He Mana te Reo o Te Papa Tongarewa He tino pūkenga e whāriki ana i ngã mahi katoa a Te Papa Tongarewa, e kapo ana i ngã tikanga mãtauranga katoa tae atu ki te mātauranga Mãori.

Te Papa is committed to excellent service Te Papa seeks to meet the needs and expectations of its audiences and communities.

E Kaingākau Ana Te Papa Tongarewa ki te Whakarite Ratonga Kairangatira E whai kaha ana Te Papa Tongarewa ki te whakarite i ngā hiahia me ngã tumanako o ngã whakaminenga me ngã rōpu-ā-iwi.

Te Papa is commercially positive Te Papa seeks to achieve successful financial outcomes and offers experiences and products that contribute to the sustainability of the Museum.

E Whai Hua Ana ngā Tauhokohoko a

Te Papa Tongarewa

E whai ana a Te Papa Tongarewa kia tika ngă whakapaunga moni, kia pai ngã whakaaturanga, kia whai tikanga ana hua, hel tautoko I ana mahi katoa. 
Appendix 3: Te Papa's Organisational Structure - Annual Report 2006/07

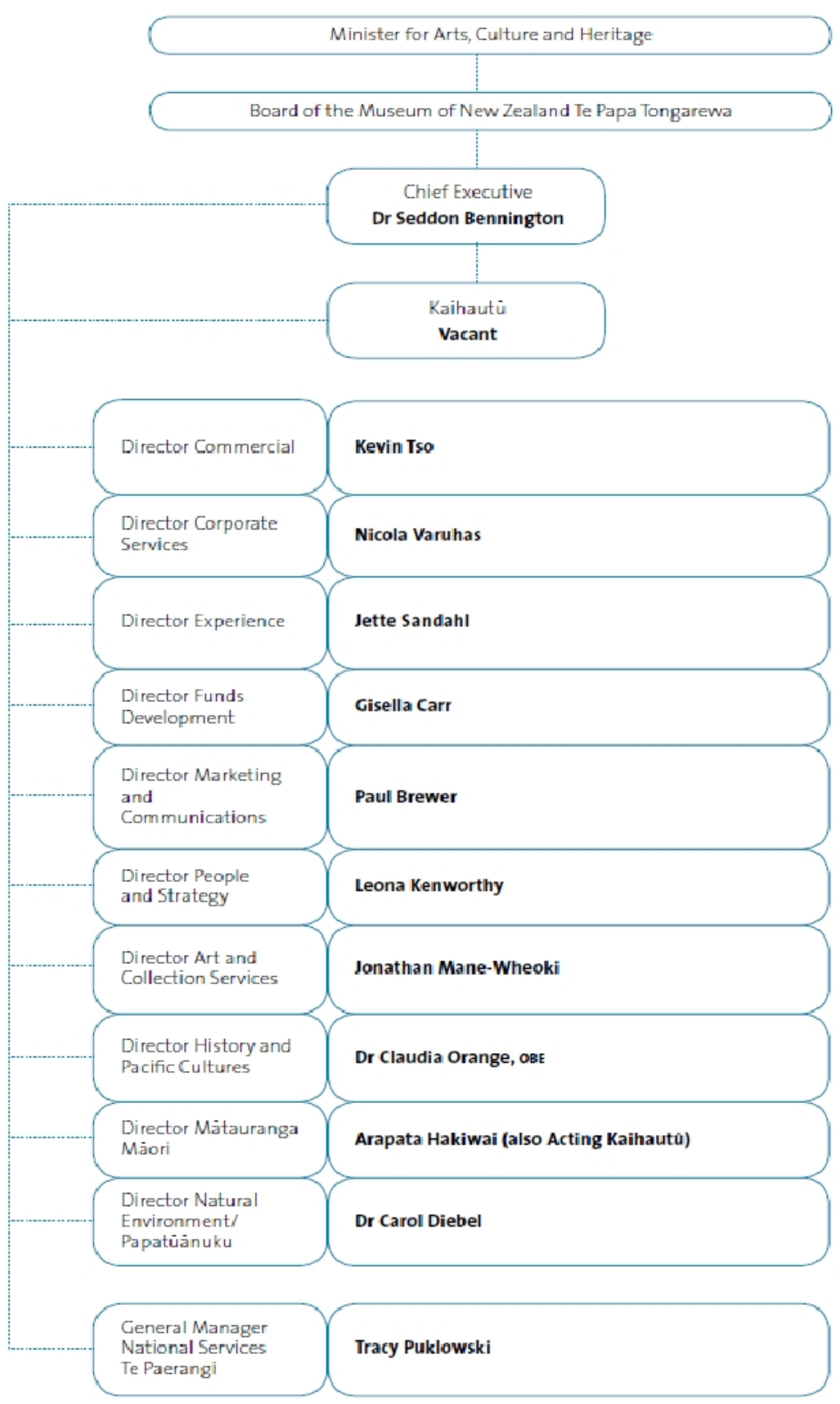




\section{Appendix 4: Te Papa's Organisational Structure - Annual Report 2007/08}

\section{Organisational Structure}

This diagram sets out Te Papa's governance.

and leadership structure as at 30 June 2008

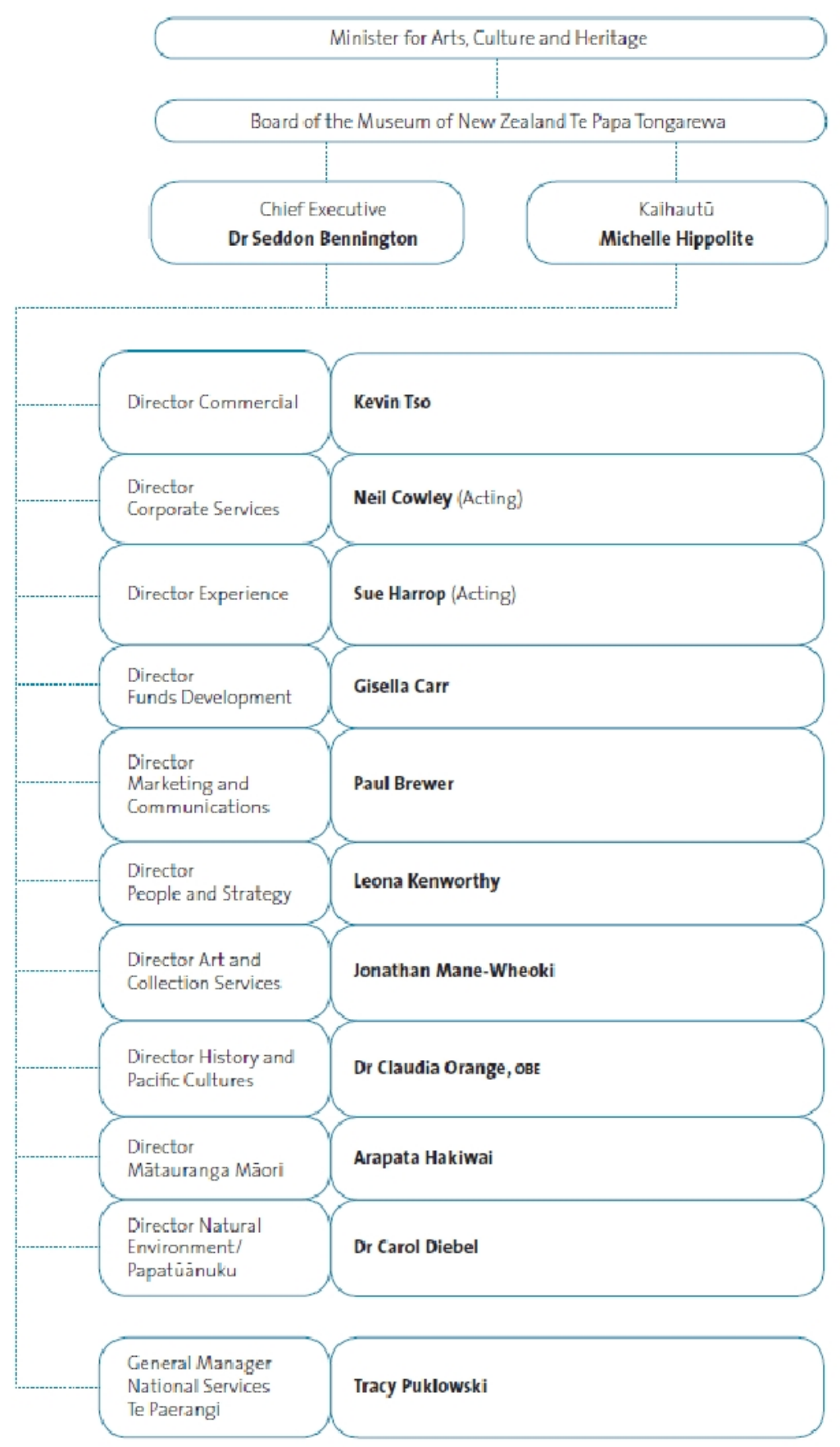


Appendix 5: Marketing poster for Mō Tātou: The Ngāi Tahu Whānui Exhibition

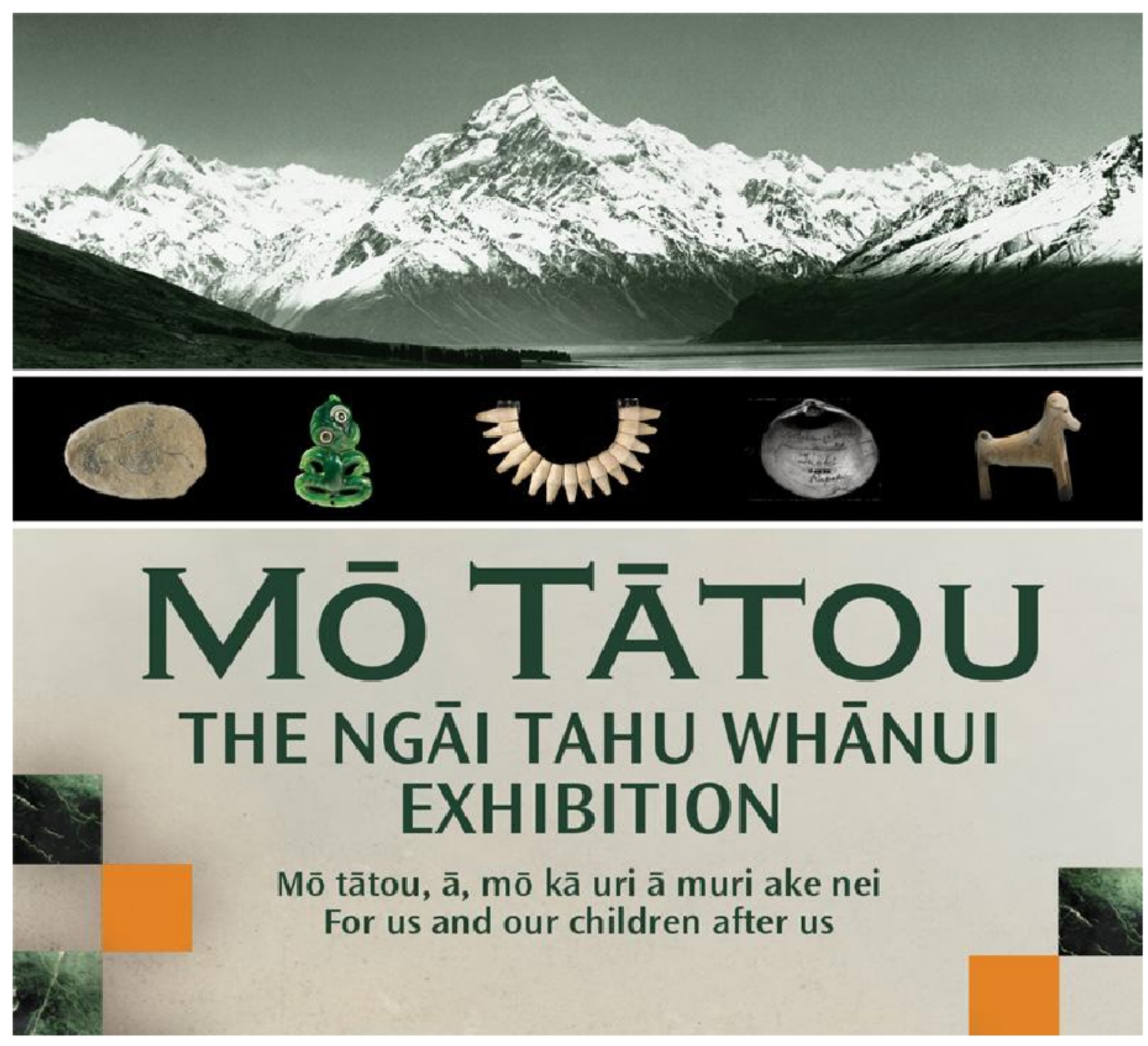

(Image: Museum of New Zealand Te Papa Tongarewa) 
Appendix 6: Floor Plans of the Mō Tātou exhibition
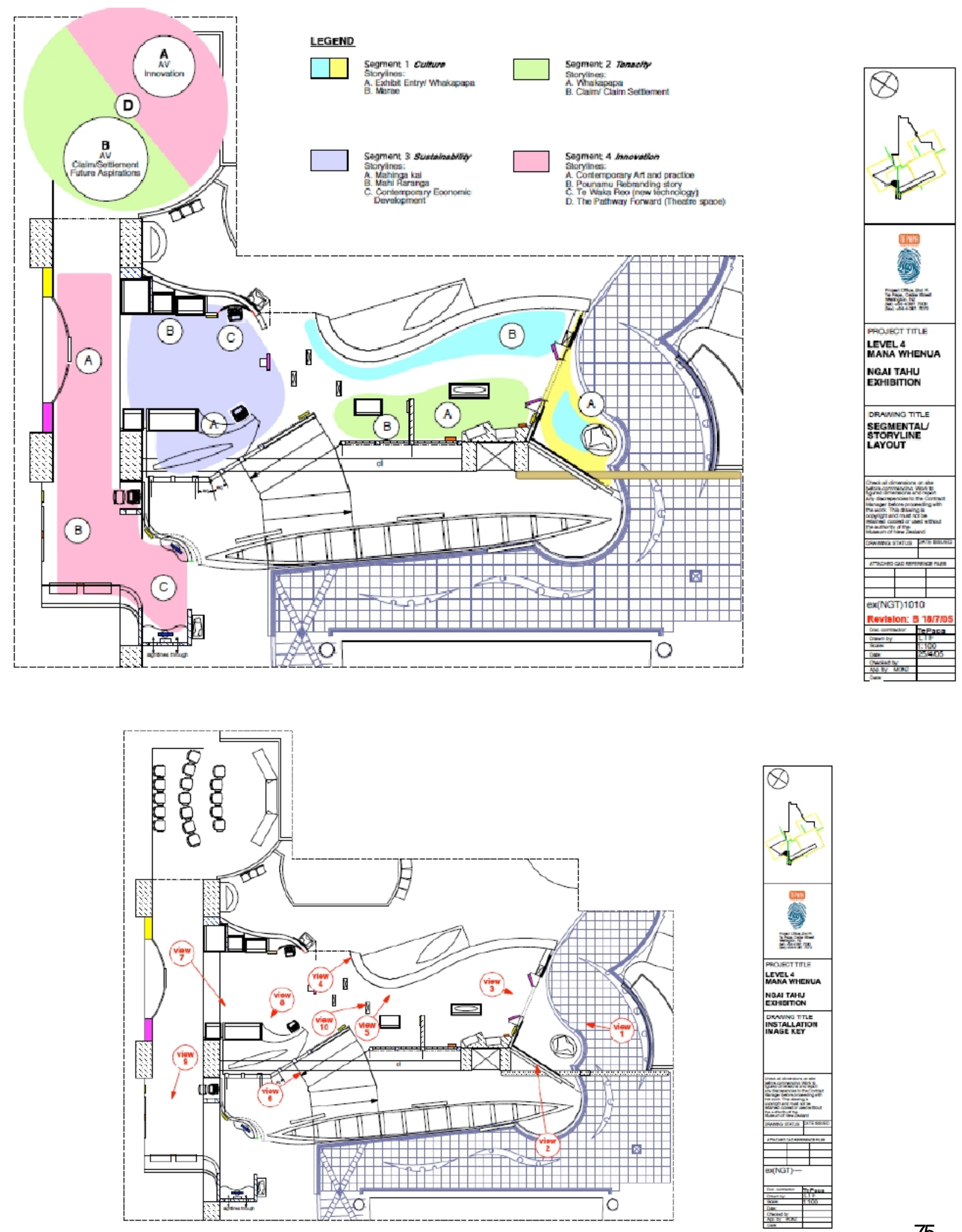
Appendix 7: Entrance to Mō Tātou exhibition

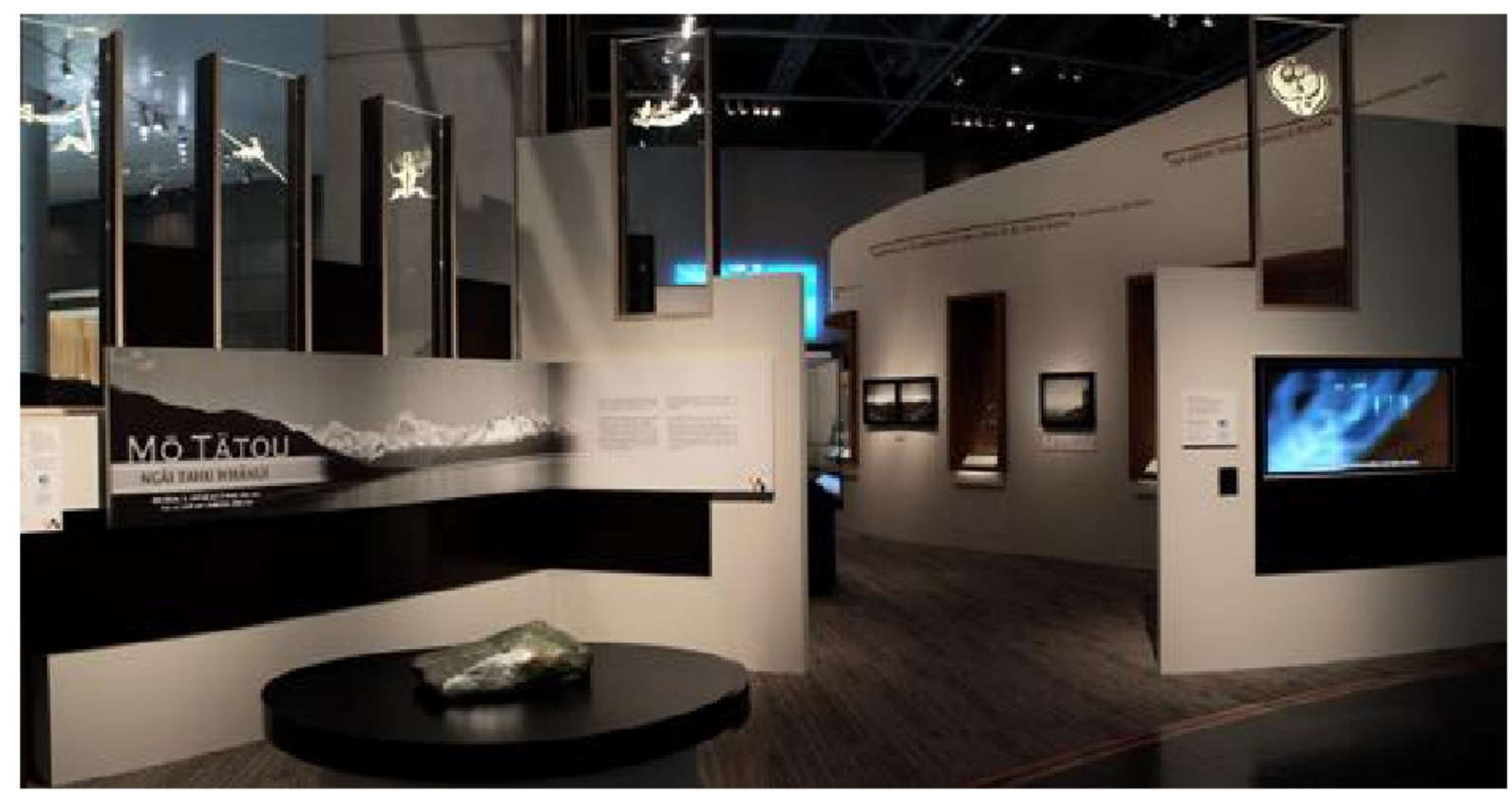

Appendix 8: Inside the exhibition space

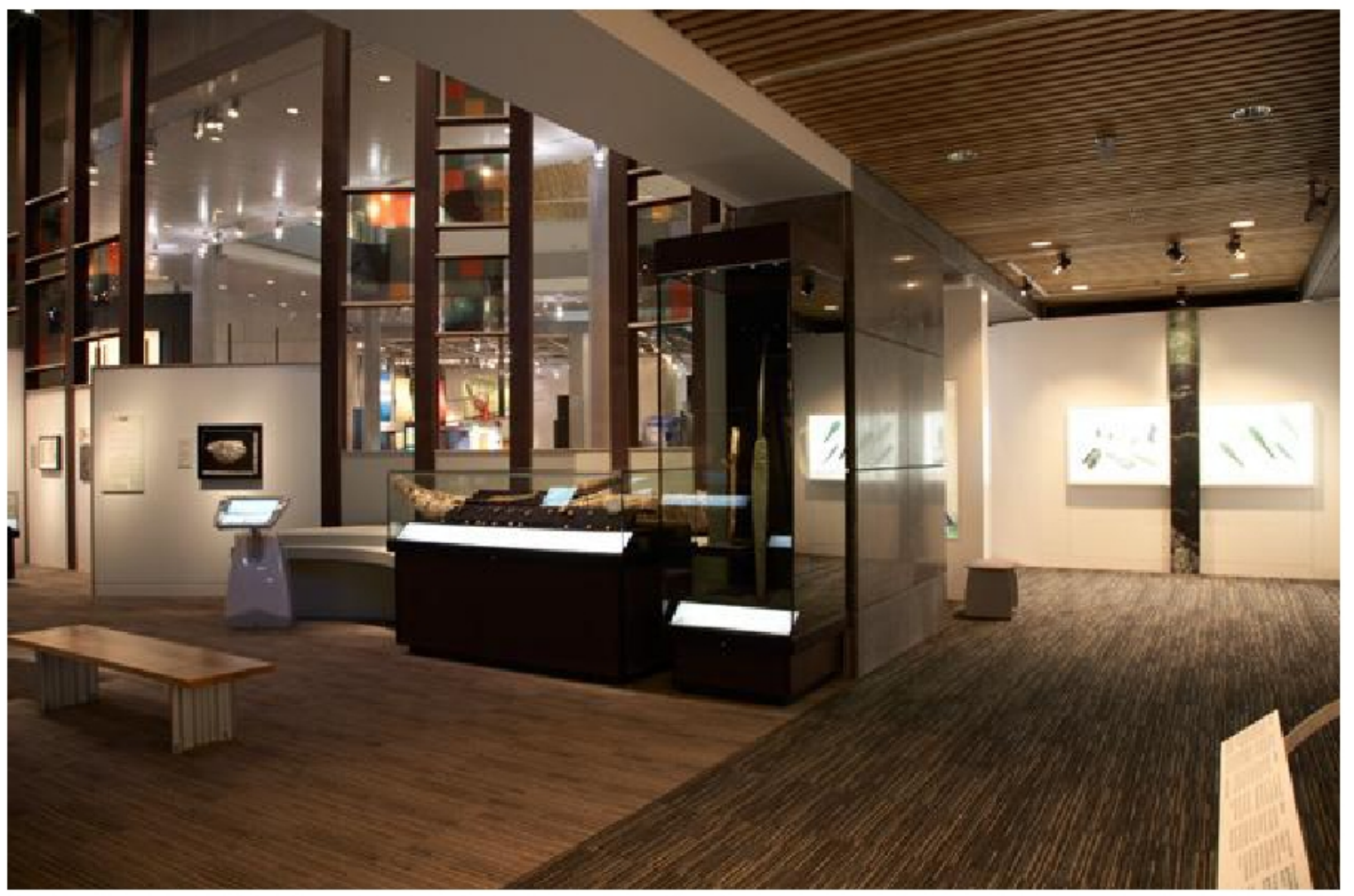

(Images: Museum of New Zealand Te Papa Tongarewa) 
Appendix 9: The Rūnanga Wall, inside the Mō Tātou exhibition at Te Papa
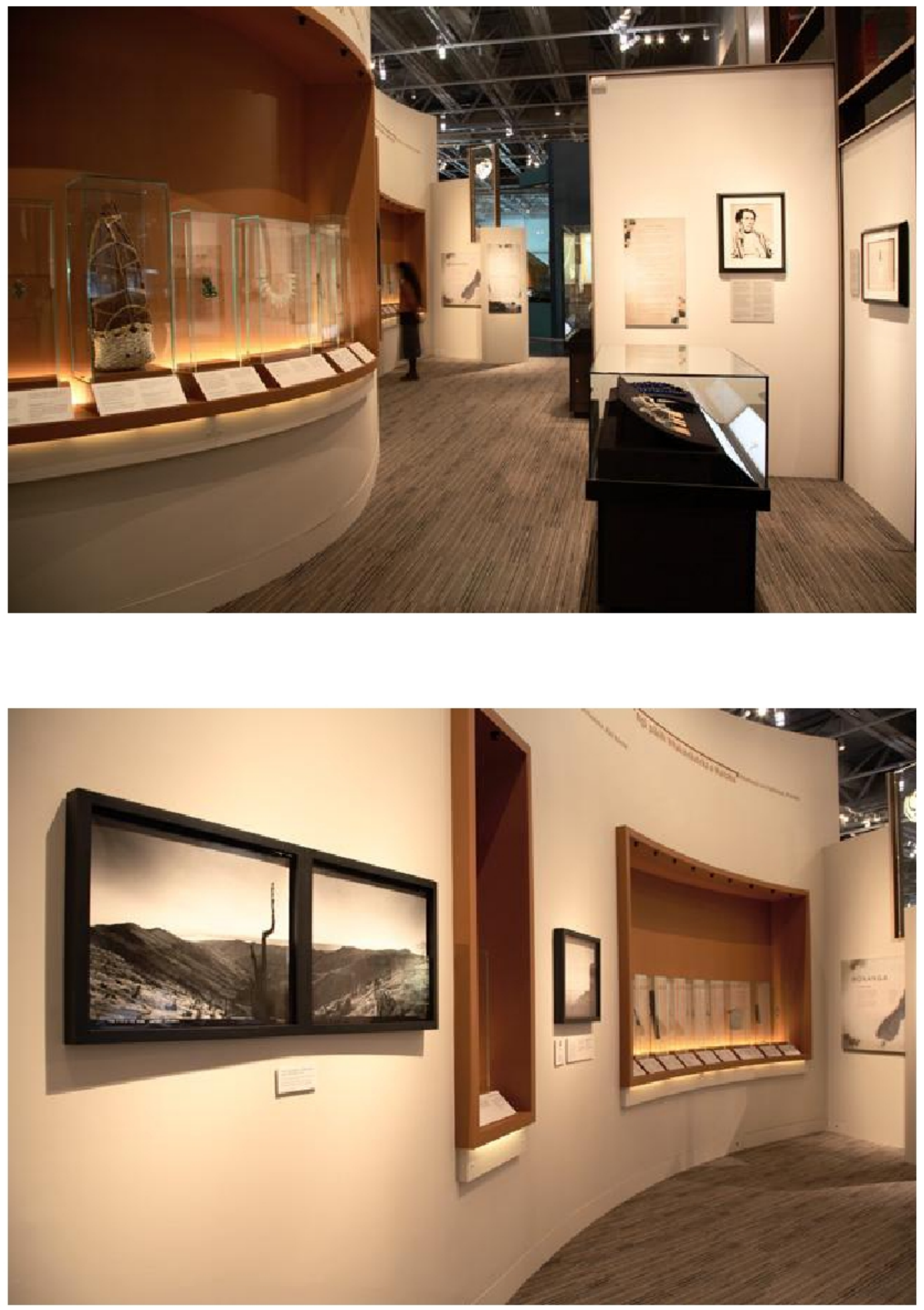

(Images: Museum of New Zealand Te Papa Tongarewa) 
Appendix 10: Meeting of elders to discuss protocol for the closing ceremony at Otago Museum, Dunedin

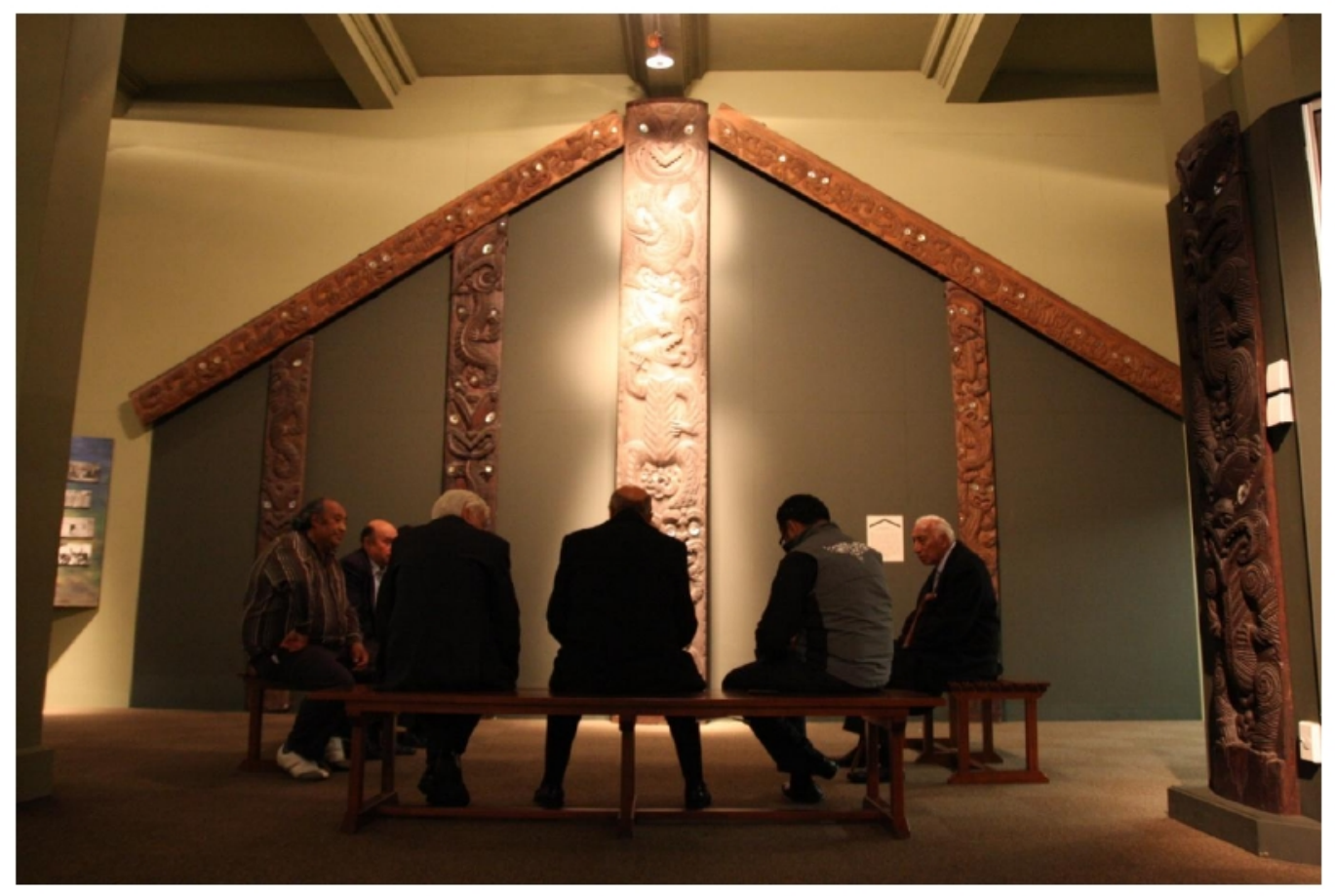

Appendix 11: Final karakia at the closing ceremony for Mo Tatou: the Ngai Tahu Whanui exhibition, Otago Museum, Dunedin

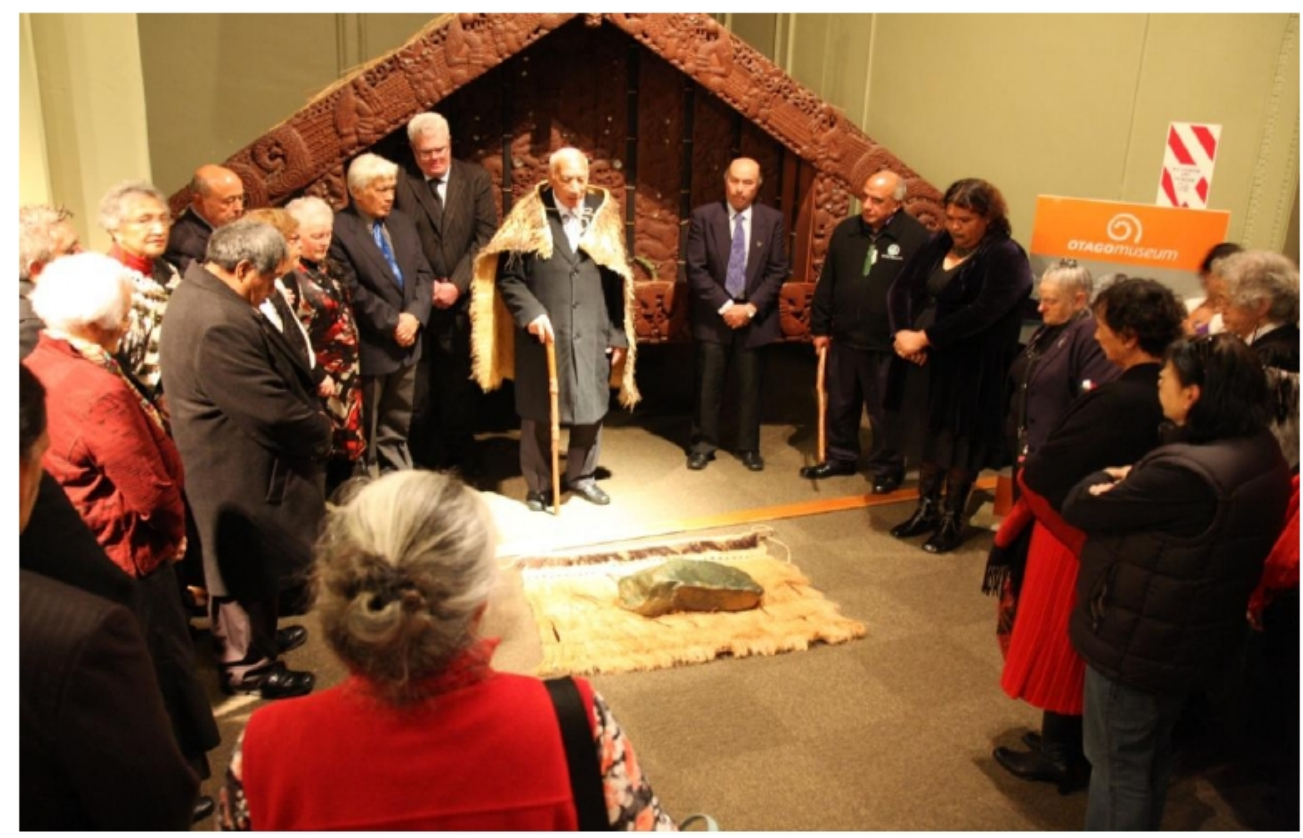

(Images: Phil Tumataroa, Te Rūnanga o Ngāi Tahu) 
Appendix 12: 'Te Maori'; the entrance touchstone, Mō Tătou exhibition at Te Papa

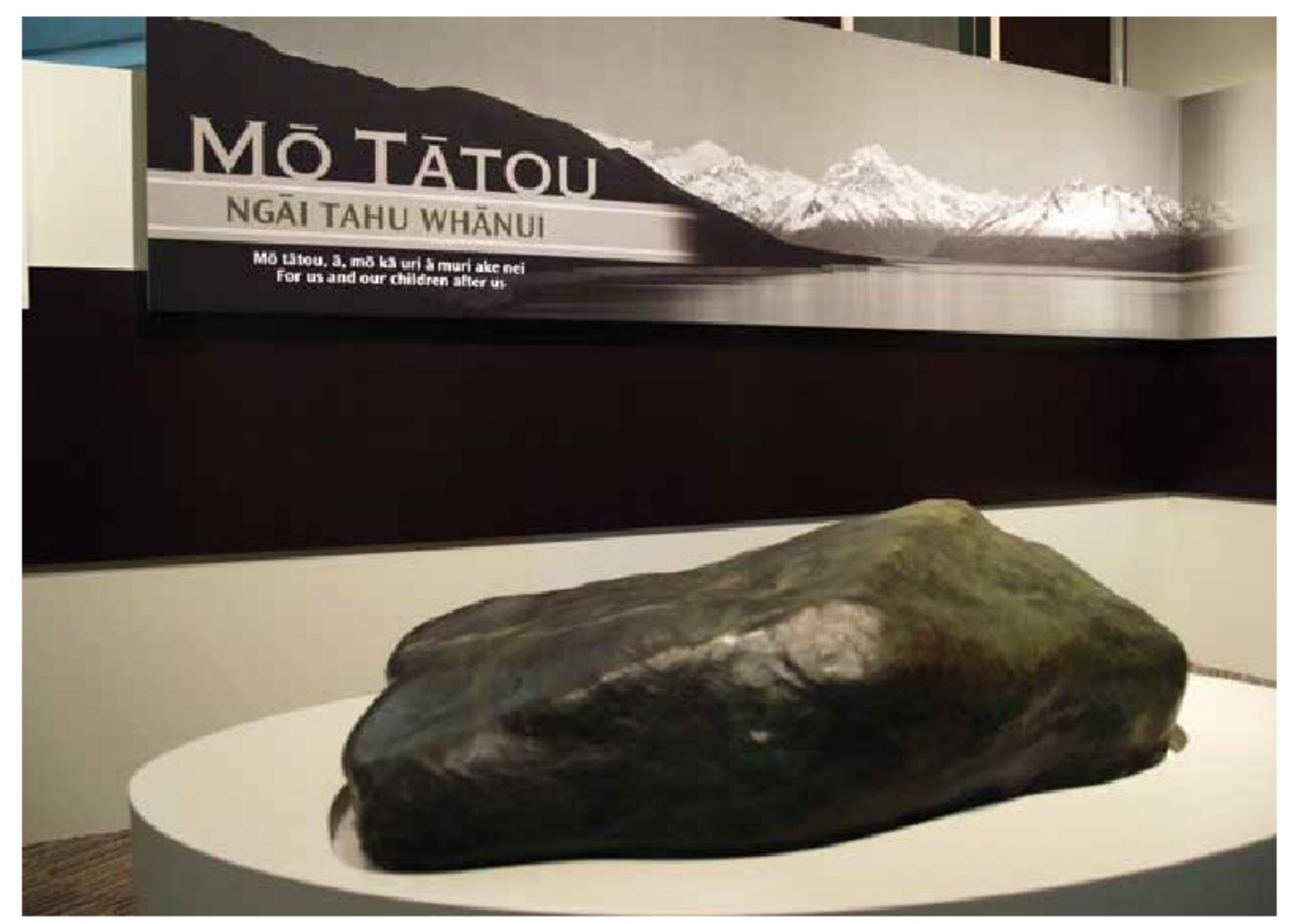

Appendix 13: Mere Pounamu case, Mō Tātou exhibition at Te Papa

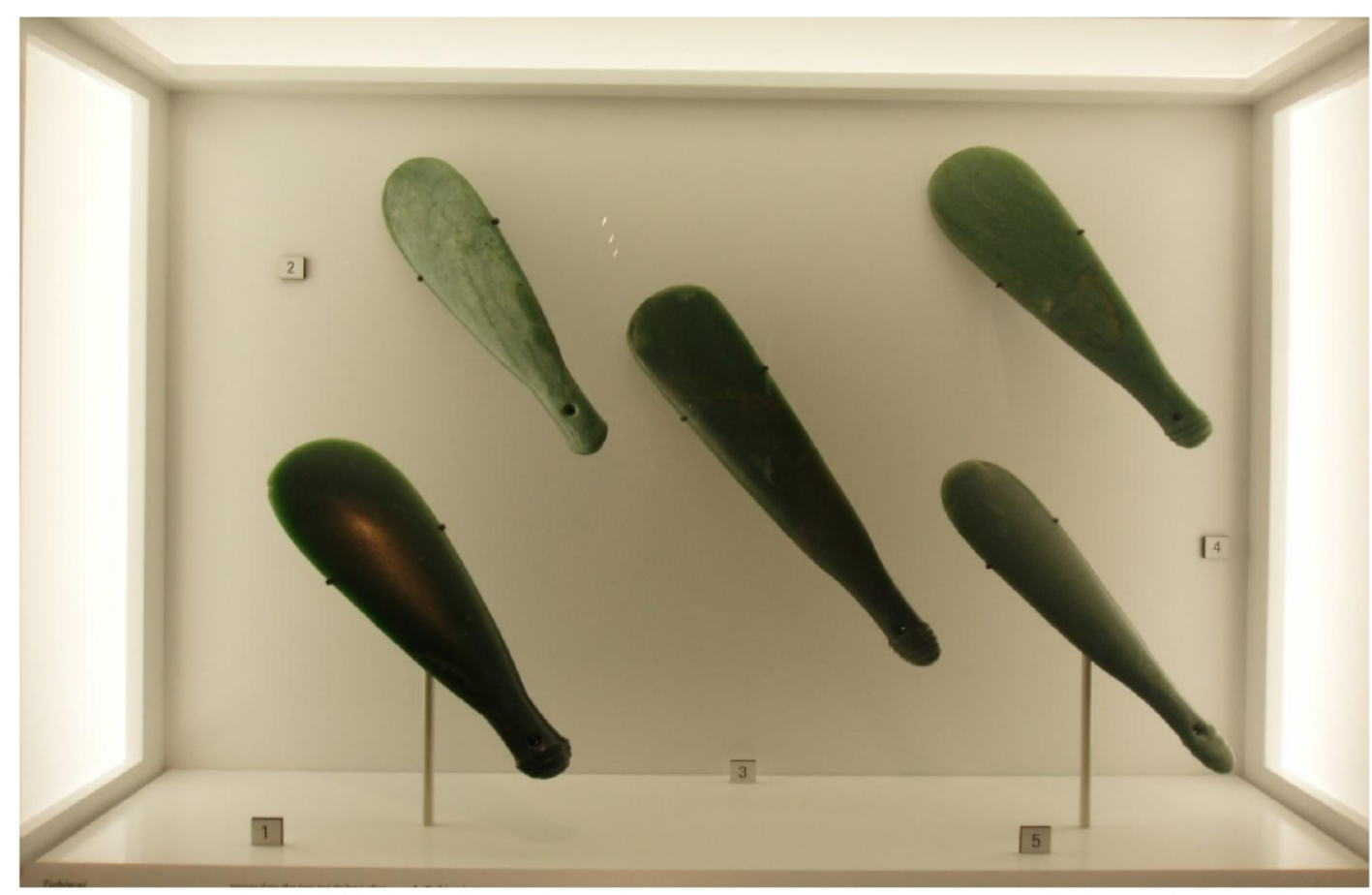

(Images: Museum of New Zealand Te Papa Tongarewa) 
Appendix 14: Opening of Mō Tātou at Te Papa, Wellington July 2006
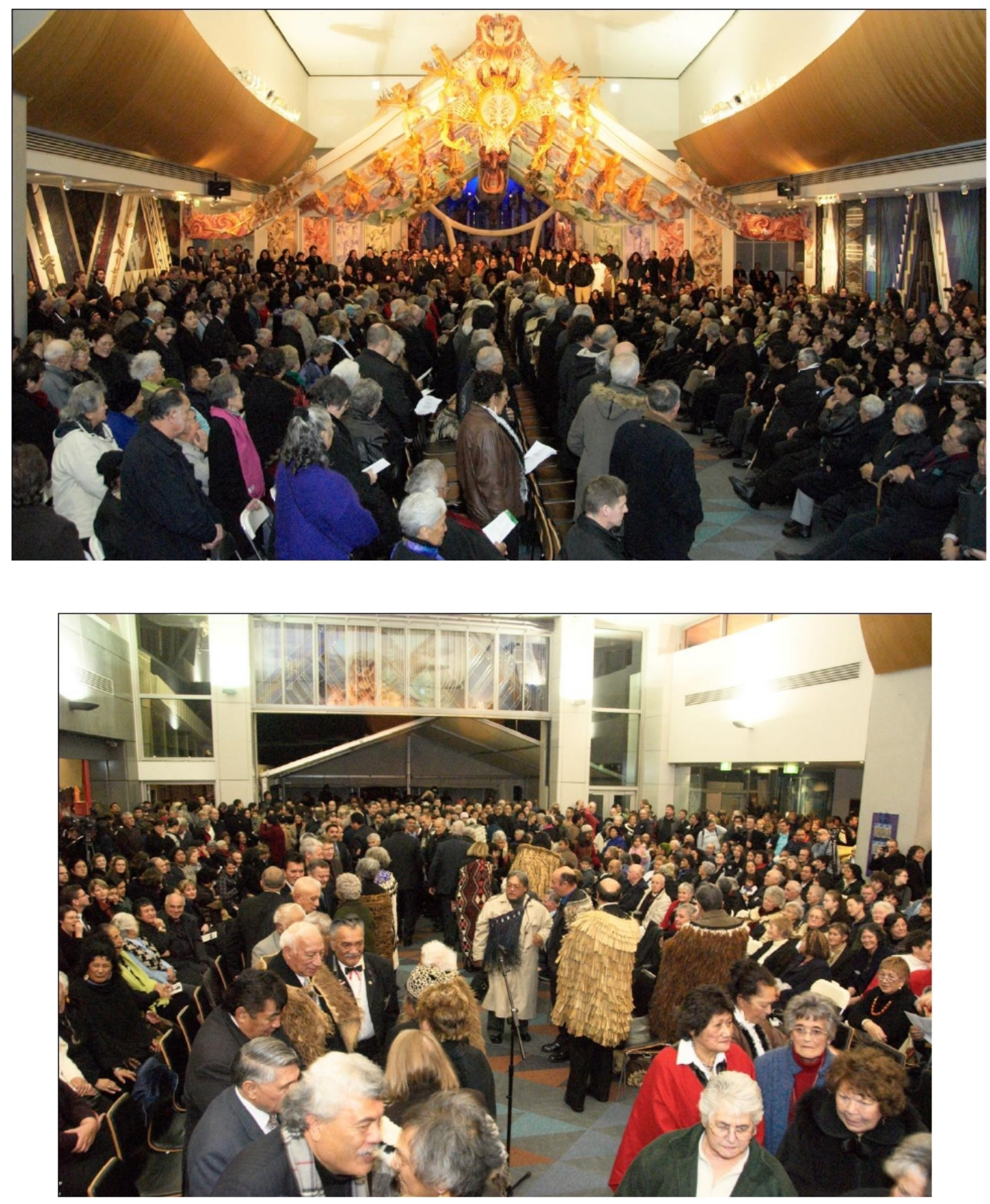

(Images: Museum of New Zealand Te Papa Tongarewa) 
Aoraki Matatu - Tihei Tahupotiki!

This survey is part of a study which examines the dynamic relationship between museums and iwi; and perhaps more importantly explores how the Mo Tatou exhibition played a role in the resurgence of iwi identity and tribal efforts to advance cultural heritage.

The survey is intended for iwi members who affiliate to Ngai Tahu, Ngati Mamoe \& Waitaha. Please note that all responses to this survey will be treated as confidential. The survey is being conducted by Ana Sciascia, who is a post- graduate student at Victoria University studying towards her masters in Museum and Heritage studies. If you have any questions regarding the survey, please do not hesitate to email Ana at motatousurvey@gmail.com

Thank you for participating in the Mo Tatou: The Ngai Tahu Whanui exhibition online survey. We anticipate it will take approximately five minutes to complete.

Ko Ruapuke te motu whakaruru, He manawa titi

Ko Makere te toa whakawhana, He kaahu korako 


\section{Mo Tatou: The Ngai Tahu Whanui Exhibition}

1. Do you affiliate to Ngai Tahu, Ngati Mamoe or Waitaha

No

Yes 


\section{Mo Tatou: The Ngai Tahu Whanui Exhibition}

2. Did you visit the Ngai Tahu Whanui exhibition Mo Tatou?

No

Yes 


\title{
Mo Tatou: The Ngai Tahu Whanui Exhibition
}

3. Where did you visit the Mo Tatou exhibition?

\author{
Te Papa, Wellington \\ Canterbury Museum, Christchurch \\ Southland Museum, Invercargill \\ Otago Museum, Dunedin
}

4. Did you attend any events associated with the Mo Tatou exhibition?

No (please go to question 6)

Yes

5. Which events associated with Mo Tatou did you attend?

\author{
Workshops \\ Performances \\ Talks \\ Tours \\ Opening/Closingceremoniese \\ Other (please specify)
}

6. Why did you visit the Mo Tatou exhibition?

7. How did you find out about the Mo Tatou exhibition?

Ngai Tahu communications (e.g. Te Panui Runaka)

Mainstream media

Whanau

Word of mouth

Other 


\title{
Mo Tatou: The Ngai Tahu Whanui Exhibition
}

8. Who did you visit the Mo Tatou exhibition with?

\author{
Family \\ Friends \\ On your own \\ School or educational institution \\ Other
}

9. Did you revisit the Mo Tatou exhibition?

No

Yes

10. Was visiting the Mo Tatou exhibition your first visit to the museum?
No
Yes

11. Please read the following statements and rate them accordingly

neither agree or

Strongly gree

agree

dis agree

strongly disagr

The Mo Tatou exhibition enhanced my

NgaiTahuidentity

The Mo Tatou exhibition reflected

mycultural aspirations

12. Did the Mo Tatou exhibition generate new cultural aspirations for you?

No
Yes
please comment 


\section{Mo Tatou: The Ngai Tahu Whanui Exhibition}

13. What are your own cultural aspirations?
Te reo
Tikanga
Whakapapa
Whanau histories
Marae revival
Mahinga Kai
Visual arts
Performing arts e
Taonga

Other (please specify)

14. Are you aware of the Ngai Tahu Cultural Fund?
No
Yes

15. Have you ever applied to the Ngai Tahu Cultural Fund?
No
Yes

16. What is your age?
Under 25
25-34
$35-44$
45-54
55-64
65-74
75 \& over 


\section{Mo Tatou: The Ngai Tahu Whanui Exhibition}

17. What is your gender?

Female

Ma le

18. Where do you live?

South Island

Nor th Island

Overseas

19. Are you registered with Te Rūnanga o Ngai Tahu?

Yes

No

20. Do you have any final comments? 


\section{Mo Tatou: The Ngai Tahu Whanui Exhibition}

Thank you for your time to complete the Mo Tatou: Ngai Tahu Whanui exhibition online survey. If you would like to go in the draw to receive a $\$ 100$ Whai rawa voucher, please send an email to motatousurvey@gmail.com with Ngai Tahu in the subject line.

Mauri Ora 


\section{Appendix 15: Intenview Questions}

1. Perhaps we could start with a brief background of yourself and your connection or role with the Mō Tātou exhibition.

2. Thinking back to development stage of Mō Tâtou, what were some of the significant issues that were encountered during the exhibition development stage; and how were they dealt with?

3. Do you consider Te Papa's Iwi exhibition programme an effective forum for iwi within the Te Papa structure? If so, why?

4. To what extent was Ngāi Tahu able to express their kaitiakitanga and tino rangatiratanga through the iwi exhibition programme and Te Papa structure?

5. How do you think Mō Tātou has enhanced iwi identity for Ngāi Tahu?

6. How has Mō Tātou advanced cultural aspirations of Ngāi Tahu

7. Lastly, this research primarily explores the evolving relationship between museums and iwi, and in this instance Te Papa and Ngāi Tahu Whanui. Is there anything else you would like to comment on before we finish? 


\section{Glossary}

hāhi - church, spiritual beliefs

hapū - extended family group, sub-tribe or section of a large tribe

hui - to meet

iwi - tribe, nation, people

kaitiaki - guardian, caretaker

kaitiakitanga / kaitiakitaka - guardianship, stewardship

kaiwhakahaere pae - cultural leaders on the marae

kaiwhakahaere - leader, chairperson

karakia - incantation, prayer

karanga - call

kawa - cultural protocols

kaumātua / poua - elder or elders, respected elderly man

kaupapa Māori - modern term referring to Māori driven project, self determination

kāwanatanga - governance

kōiwi tangata - skeletal remains

kōrero - speak, conversation,

kōwhaiwhai - painted pattern

kuia / taua - respected elderly women

mahinga kai - food-gathering practices

mahi raranga - weaving

mana - power, authority, prestige, respect

manaakitanga - the hosting of visitors, care of others

mana taonga - the power, authority and responsibility associated with the possession of

taonga

mana whenua - the power, authority and responsibility arising from the local tribe who claim

occupation rights over a specific territory

manuhiri - visitors

Māoritanga -in modern times denotes Māoriness, Māori culture

marae - space in front of meeting house

Matariki - Māori New Year - marked by constellation rising in early June

mātauranga Māori - modern term referring to the Māori system of knowledge or world view,

mauri - spark of life, life essence

mere pounamu - greenstone weapon

mihi - greet, acknowledge

mokamokai - preserved human head often tattooed

Ngai Tahutanga / Kai Tahutanga - Ngai Tahu cultural identity

noa - balance, neutrality

paepae - threshold of house, line of kaumātua at welcome ceremony

Pākehā - person of European descent

Papa, Papatūānuku - mother earth

papa - land, earth

pepeha - proverb, saying

pounamu - greenstone

rangatira - chief

rangatiratanga - chieftainship, chiefly authority, power or sovereignty

rūnanga/rūnaka - tribal council

rua kōiwi - caves where skeletal remains where hidden

tāngata / tākata - people (pl.) 
tangata whenua - people of the land, indigenous people (Māori)

tangi, tangihanga - grief / funeral ceremony

taonga/taoka - treasure, property, anything highly prized

taonga tuku iho - treasures handed down (literal), precious heritage

tautoko - support

tapu - sacred, special

Te Kereme - Ngāi Tahu Treaty of Waitangi claim

Te reo - the Māori language

tikanga - customary practice

tiriti - treaty

tohora - whale

tono - approach, appeal, request

tūpāpaku - corpse

tupuna/tipuna - ancestor(s)

wairua -spirit, soul

waka tūpāpaku - burial chest for bones and human remains, coffin

wairua - soul, spirit, spirituality

wānanga - learning forum, caucus

whaikōrero - oration, formal speech

whakairo - to orament with a pattern, in modern usage refers to wood carving

whakanoa - remove tapu

whakapapa - genealogy

wharenui - ancestral house

whānau - family

whānaungatanga / whānaukataka - relationships

(Williams 1971, Ngata 1993, Mead 2003, Royal 2004, Sciascia pers. comm. 26 July 2011)

Note: In some instances the Southern dialect of the Māori language replaces the 'ng' with a ' $\mathrm{k}$ '; hence Kāi Tahu is sometimes used for Ngāi Tahu, etc. In regard to Mō Tātou: the Ngāi Tahu Whānui exhibition, Ngāi Tahu requested that they be referred to as Ngāi Tahu and not the dialectal variation Kāi Tahu within Te Papa and in all documentation relating to the iwi (Te Papa 2005). 


\section{Bibliography}

Avnon, Dan. Martin Buber: The Hidden Dialogue. Lanham MD: Rowman \& Littlefield, 1998.

Bananthy, B. \& Jenlink, P., eds. Dialogue as a means of collective communication. New York: Kluwer Academic / Plenum, 2005.

Battiste, M \& Youngblood Henderson, eds. Protecting Indigenous knowledge and heritage: a global challenge. Saskatoon: Purich Publishling, 2000.

Bjerregaard, Peter. The Materiality of Museum Politics: Reflections on objects and agency in contemporary museum practice. Aarhus: University of Aarhus, 2006.

Butts, David. "Maori and Museums: The Politics of Indigenous Recognition." PhD thesis, Massey University, 2003.

Butts, D. "Māori and museums: The politics of indigenous recognition." In Museums, society, inequality, edited by R. Sandell. 225-243. London; New York: Routledge, 2002.

Carbonell, B.M, ed. Museum Studies: an anthology of contexts. Maldern: MA Blackwell Pub., 2004.

Clifford, James. "Museums as Contact Zones," in Routes: Travel and Translation in the Late Twentieth Century. 192. Harvard University Press, Cambridge, 1997.

Coombes, Annie, ed. Rethinking Settler Colonialism: History and Memory in Australia, Canada, Aotearoa New Zealand and South Africa. Manchester University Press, Manchester, 2006.

Corsane, G., ed. Heritage, museums and galleries: An introductory reader. New York; London: Routledge, 2004.

Durie, Mason. Mauriora: The Dynamics of Maori Health.Auckland: Oxford University Press, 2001.

Durie, Mason. Te Mana, Te Kawanatanga: The Politics of Maori Self-Determination. Auckland: Oxford University Press, 1998.

Fleras, Augie, \& Paul Spoonley. Recalling Aotearoa: Indigenous Politics and Ethnic Relations in New Zealand Auckland: Oxford University Press, 1999.

Fleras, Augie. "Politicising Indigeneity: Ethno-Politics in White Settler Dominions." In Indigenous Peoples' Rights on Australia, Canada and New Zealand, edited by Paul Havemann. 187-234. Auckland: Oxford University Press, 1999.

Gathercole, P.E., ed. The politics of the past (Vol.;12). London; Boston: Routledge, 1994.

Greer, S. "Ojibwa storyteller speaks out against film." Kaninai News. 14-15. 1989, November 9. 
Hakiwai, Arapata. "The Search for Legitimacy: Museums in Aotearoa, New Zealand - a Maori Viewpoint." In Heritage, Museums and Galleries: An Introductory Reader, edited by Gerard Corsane. 154-62. London and New York: Routledge, 2005.

Hall, S. Representation: Cultural representations and signifying practices. London: Sage / Open University, 1997.

Hendry, Joy. Reclaiming Indigenous Culture: Indigenous People and Self-Representation. New York: Palgrave MacMillan, 2005.

Henare, Amiria. Museums, Anthropology and Imperial Exchange. New York: Cambridge University Press, 2005.

Henare, Amiria. "Taonga Maori: Encompassing Rights and Property in New Zealand." In Thinking through Things: Theorising Artefacts in Ethnographic Perspective edited by Amiria Henare, Martin Holbraad and Sari Wastell. 47-67. London and New York: Routledge, 2007.

Hill, Richard S. Maori and the State: Crown-Maori Relations in Aotearoa/New Zealand 1950-2000. Wellington: Victoria University Press, 2009.

Hooper-Greenhill, E. "Changing values in the art museum: rethinking communication and learning." In Museum Studies: an anthology of context, edited by Carbonell, Maldern. 556576. MA: Blackwell Pub., 2004.

Isaacs, W.N. "Creating a shared field of meaning: An action theory of dialogue" In The Transformative Power of Dialogue (Research in Public Policy Analysis and Management, Volume 12 edited by Nancy C. Roberts. 203-241. Emerald Group Publishing Limited, 2002.

Isaacs, William, N. Dialogue and the art of thinking together: a pioneering approach to communicating in business and in life currency. New York: Doublebay, 1999.

Karp, Ivan, and Lavine, eds. Exhibiting Cultures: The Poetics and Politics of Museum Display. Washington: Smithsonian Institution Press, 1991.

Kirshenblatt-Gimblett, Barbara. Destination Culture: Tourism, Museums, and Heritage. Berkeley: University of California Press, 1998.

King, N. "Relationships in Research: Human Reality, Ethical Challenge" in Tikanga Rangahau Matauranga Tuku Iho, Traditional Knowledge and Research Ethics Conference. Auckland: Auckland University, 2004.

Kreps, Christina F. Liberating Culture: Cross-Cultural Perspectives on Museums, Curation, and Heritage Preservation, Museum Meanings. London; New York: Routledge, 2003.

Kreps, C. "Non-Western Models of Museums and Curation in Cross-Cultural Perspective." In a A Compaion to Museum Studies, edited by Sharon MacDonald 457-72. Malden MA: Blackwell Publishing, 2006. 
Latour, Bruno. "From Realpolitik to Dingpolitik: Or How to Make Things Public.' In Making Things Public: Atmospheres of Democracy. Catalogue for the exhibition Making Things Public at ZKM Center for Art and Media, Karlsruhe. Cambridge; Massachussets: MIT Press, 2005.

Lidchi, Henrietta "The Politics and Poetics of Exhibiting Other Cultures." In Representation: Cultural Representations and Signifying Practices, edited by Stuart Hall, 153-208. London: Sage/Open University, 1997.

Lonetree, A. \& Cobb-Greetham, eds. The National Museum of the American Indian: Critical Conversations, University of Nebraska, 2008.

Maaka, R. \& Augie, F. The politics of Indigeneity - Challenging the state in Canada and Aotearoa New Zealand. Dunedin: Otago Press, 2005.

MacDonald, Sharon. The Politics of Display: Museums, Science, Culture. London: Routledge, 1998.

McCarthy, Conal. Exhibiting Māori: A history of colonial cultures of display. Oxford \& New York: Berg, 2007.

McCarthy, Conal. "From Curio to Taonga: A Genealogy of Display at New Zealand's National Museum, 1865 - 2001." PhD, Victoria University of Wellington, 2004.

McCarthy, Conal. Museums and Māori:Heritage, Professionals, Indigneous Collections, Current Practice. Wellington: Te Papa Press, 2011.

McClean, R. "Ngai Tahu Shares its treasures." The Dominion Post, p.b7. 2006, July 14.

Mead, Hirini M. Magnificent Te Maori: Te Maori Whakahirahira. Auckland: Heinemann, 1986.

Mead, Sidney M., ed. Te Maori: Maori Art from New Zealand Collections. New York: Abrams: American Federation of Arts, 1984.

Mead, H.M. Tikanga Maori: Living by Maori Values. Wellington: Huia, 2003.

Mead, H.M. Maori Art on the World Scene: Essays on Maori Art. Wellington: Ahua Design \& Illustration Ltd.; Matau Associates, 1997.

Message, Kylie. New Museums and the Making of Culture. Oxford, New York: Berg, 2006.

Metge, J. \& Kinloch,P. Talking Past Each Other: Problems of Cross-Cultural Communications. Wellington: VUW Press, 1984.

Mey, Vera. "Commonplace: Towards a post-ethnic understanding of identity and representation of Asian New Zealanders for museum practice." Masters dissertation, Victoria University, 2010.

Mullholland, Melcom. State of the Maori Nation: twenty first century issues in Aotearoa. Auckland: Reed Publishing, 2006. 
Museums Aotearoa Te Tari o Nga Whare Taonga o te Motu. A Strategy for the Museum Sector in New Zealand. Wellington: Ministry of Culture and Heritage, 2005.

Museum of New Zealand Te Papa Tongarewa "Matauranga Maori and Museum Practice." In He rauemi: Resource Guides Issue No. 31. Wellington: National Services Te Paerangi, Author , 2006.

Museum of New Zealand Te Papa Tongarewa. Icons Nga Taonga from the Museum of New Zealand Te Papa Tongarewa. Wellington: Te Papa Press, 2004.

Museum of New Zealand Te Papa Tongarewa. Te Papa Tongarewa Statement of Intent 2010/11, 2011/12, 2012/13. Wellington: Author, 2010.

Museum of New Zealand Te Papa Tongarewa. Te Papa Tongarewa Annual Report 2006-07. Wellington: Author, 2007.

Museum of New Zealand Te Papa Tongarewa. Te Papa Tongarewa Annual Report 2007-08. Wellington: Author, 2009.

Nederveen-Pieterse, J. "Multiculturalism and museums: discourse about others in the age of globalization." In Heritage, museums and galleries: An introductory reader edited by G. Corsane. 163-184. New York and London: Routledge, 2004.

Nichol, Lee, ed. Bohm on dialogue. New York: Routledge, 1996.

O'Regan, Gerard. "Bicultural Developments in Museums of Aotearoa: What Is the Current Status? Ki Te Whakamana I Te Kaupapa Tikanga-a-Rua Ki Roto I Nga Whare Taonga O Te Motu: Kei Hea E Tu Ana?" Wellington: Te Papa National Services, Museums Association of Aotearoa, 1997.

O'Regan, Hana. Ko Tahu, Ko Au: Kai Tahu Tribal Identity. Christchurch: Horomaka Publishing, 2001.

O'Sullivan, Dominic. Beyond Biculturalism: The Politics of an Indigenous Minority. Wellington: Huia, 2007.

Peers, Laura, \& Alison K. Brown, eds. Museums and Source Communities: A Routledge Reader. London: Routledge, 2003.

Piper, H. \& Simons, H. "Ethcial responsiblitiy in social research." In Research Methods in the Social Sciences edited by Somekh, B. \& Lewin, C. 56-63. London; Thousand Oaks; New Delhi: Sage, 2005.

Powick, Kiri. Māori Research Ethics: A literature of the ethical issues and implication of kaupapa Māori research involving Māori for researchers, supervisors and ethics committees. Hamilton: University of Waikato, 2003.

Sarantakos, S. "Introduction, Section 3: 'Politics and the production of knowledge'." In

Social Research 3 ${ }^{\text {rd }}$ Edition. 13-27. Basingstoke: Palgrave MacMillan, 2005. 
Shelton, A. Museums and anthropologies: Practices and narratives. In A companion to museum studies edited by S. Macdonald. 64-8. Malden, MA: Blackwell, 2006.

Simpson, Moira G. Making Representations: Museums in the Post-Colonial Era. London; New York: Routledge, 1996.

Sissons, Jeffrey. First Peoples: Indigenous Cultures and Their Futures, Focus on Contemporary Issues. London: Reaktion, 2005.

Sleeper-Smith, Susan. Contesting Knowledge: Museums and Indigenous Perspectives. Lincoln; London: University of Nebraska Press, 2009.

Smith, L. "On Tricky Ground." In The Sage Handbook of Qualitative Research $3^{\text {rd }}$ Edition edited by Denzin, N. \& Lincoln, Y. 85-109. London; Thousand Oaks; New Delhi: Sage, 2006.

Smith, Linda Tuhiwai Decolonising Methodologies: Research and Indigenous Peoples. Dunedin: University of Otago Press, 1999.

Smith, Huhana. E Tu Ake: Mãori standing tall. Wellington: Te Papa Press, 2011.

Tapsell, P. "Beyond the Frame: An Afterword." In Museums and Source Communities: A Routledge Reader edited by Peers \& Brown. 242-251. London: Routledge, 2003.

Tapsell, P. "From the sideline: Tikanga, Treaty Values and Te Papa." In Waitangi Revisited: Perspectives on the Treaty of Waitangi edited by M. Belgrave, M. Kawharu \& D. Williams. 266-282. Melbourne: Oxford University Press, 2004.

Tapsell, P. "Out of sight, out of Mind: Human Remains at the Auckland Museum Te Papa Wakahiku." In Looking reality in the eye: museums and social responsibility edited by Janes, R. \& Conaty. 153-171. Canada: G. University of Calgary Press, 2005.

Tamarapa, A. "Museum Kaitiaki: Māori Perspectives on the Presentation and Management of Māori Treasures and Relationships with Museums - Redefining the Keeping Place." In Curatorship: Indigenous perspectives in postcolonial societies. 160-169. Ottawa: Canadian Museum of Civilization, 1996.

Tau, T, Anderson, A and Carringlton, A. Ngāi Tahu: a migration history: the Carrington text. Wellington: Bridget Williams Books, 2008.

Te Runanga oNgai Tahu. Ngai Tahu 2025. Christchurch: Author, 2001.

Thomas, David R. A general inductive approach for qualitative data analysis School of Population Health, Auckland: University of Auckland, 2003.

Tumataroa, P., ed. Te Karaka - Winter 2006 vol 31. Christchurch: Ngāi Tahu Publications, 2006.

Walker, Ranginui. Ka Whawhai Tonu Matou: Struggle without End. Auckland: Penguin, 1990.

Witcomb, Andrea. Re-Imagining the Museum. London: Routledge, 2003. 


\section{Journal articles}

Barr, Sandi Hinerangi. "Mo Tatou return." Te Karaka Kana/Spring, no.44 (2009): 26-28

Butts, David. "Co-Operative Redevelopment Planning: First Steps." AGMANZ Journal Dec, no. 15.4 1984): 23-4.

Cram,F. (1997) 'Developing partnerships in research: Pakeha researchers and Māori research', Sites, No. 35:44-63.

Eden, S. "Few, if any full Māori left comment horrifies." The Domionin Post. 27 September (2006): 2.

Fox, Derek. "Tahu’s turnout at Te Papa." Mana Magazine August/September no.71 (2006): 8283.

Gathercole, Peter. "Te Maori in the Longer View." Pacific Art: Persistence, Change and Meaning, edited by Anita Herle. Honolulu: University Press of Hawai'i, (2002): 271-9.

Hanson, Allan. "The Making of the Maori: Culture Invention and Its Logic." American Anthropolgist, New Series, Vol. 91, No.4 (Dec., 1989): 890-902.

Henare, Amiria. "Rewriting the Script: Te Papa Tongarewa the Museum of New Zealand." Social Analysis 48, no. 1 (2004): 55-63.

Irwin, K. "Maori research methods and processes." An Exploration of Sites 28 (1994): 24-43.

Lidchi, Henrietta. "Culture and Constraints: Further Thoughts on Ethnography and Exhibiting." International Journal of Heritage Studies 12, no. 1 (2006): 93-114.

Mead, Sidney Moko. "Concepts and Models for Maori Museums and Culture Centres." AGMANZ Journal 16, no. 3 (1985): 3-5.

O’Regan, Gerard. "Biculturalism, the Treaty and the Spirit of Partnership." New Zealand Museums Journal 26, no. 2 (1997): 28-30.

Maaka, Roger, and Augie Fleras. "Politicising Property Rights: Tino Rangatiratanga as Constructive Engagement." Sites, no. 35 (1997): 20-43.

Message, Kylie. "Representing Cultural Diversity in a Global Context: The Museum of New Zealand Te Papa Tongarewa and the National Museum of Australia." International Journal of Cultural Studies 8, no. 4 (2005): 465-85.

Salmond, A. "Ngā rakau a te pākēha: reconsidering Māori anthropology." Anthropology and Science epistemologies in practices Auckland Academia Education (May 2006).

Tafuna’i, F., ed. "Poua Kukupa honoured." Te Karaka Kana/Spring, no.44 (2009): 9.

Tafuna’i, F., ed. "Enduring Significance." Te Karaka Makariri/Winter no.50 (2011):44-48.

Te Panui Runaka, ed. "Mo Tatou." Te Panui Runaka Rima/September (2009):22-23 
Te Panui Runaka, ed. "Mo Tatou - the Ngai Tahu Whanui exhibition." Te Panui Runaka Rima/September (2009): 11

Walker, S., Eketone, A. \& Gibbs, A. "An exploration of kaupapa Māori research, its principles, processes and applications." International Journal of Social Research Methodology, Vol.9(4) (2006): 331-344.

\section{Professional papers}

Ames, Michael. "Biculturalism in Exhibits." In Taonga Maori Conference New Zealand November 18-27, 1990, edited by Mark Lindsay, 27-39. Wellington: Cultural Conservation Advisory Council, Department of Internal Affairs, 1991.

Smith, Graham. "Kaupapa Maori Theory: Theorizing Indigenous Transformation of Education and Schooling." Kaupapa Maori Symposium, NZARE / AARE Joint Conference, Hyatt Hotel, Auckland, December 2003.

Fleras, Augie, and Roger Maaka. "Mainstreaming Indigeneity: Indigenising the Policy Making Paradigm in Aotearoa New Zealand and Canada." Canada and New Zealand: Connections, comparisons and challenges. Wellington: Victoria University of Wellington, 2010.

\section{Websites}

Bohm Dialogue. Accessed April 2011:

http://www.david- bohm.net/dialogue/dialogue_proposal.html

Dance dictonary (Raper 1998). Accessed May 2011:

http://www.dancedictionary.com/TermsAlpha.html

Dialogue Digest. Accessed May 2011: http://www.soapboxorations.com/ddigest/index.htm

The Otago Daily Times. Accessed June 2011:

http://www.odt.co.nz/news/dunedin/137213/ngai-tahu-exhibition-due

MarlboroughExpress. Accessed June 2011:

http://www.stuff.co.nz/marlboroughexpress/news/kaikoura/3225882/Ngai-Tahu-exhibit

NZ Museum. Accessed May 2011: http://www.nzmuseums.co.nz/news/the-ngai-tahuwhanui-exhibition-opens-at-otago-museum/

Rangahau. Accessed April 2011: http://www.rangahau.co.nz/research-idea/27/

Statistics New Zealand. Accessed June 2011:

http://www2.stats.govt.nz/domino/external/pasfull/pasfull.nsf/173371ce38d7627b4c2568090 0046f25/4c2567ef00247c6acc256b6d0009346f?OpenDocument

Te Ana Rock Art Centre. Accessed July 2011:http://www.teana.co.nz

Te Ara Encyclopaedia of New Zealand. Accessed July 2011: http://www.teara.co.nz 
Te Karaka website. Accessed April 2011: http://www.tekaraka.co.nz/Te-Karaka44/MoTatou/

The Museum of New Zealand Te Papa Tongarewa. Accessed February 2011: http://www.tepapa.govt.nz

The Ngāi Tahu Fund. Accessed April 2011: http://www.ngaitahufund.com

Te Rūnanga o Ngāi Tahu. Accessed February 2011: http://www.ngaitahu.iwi.nz/

The Press. Accessed June 2011: http://www.stuff.co.nz/the-press/lifestyle/3347673/To-speakthe-past

The Southland Times. Accessed June 2011: http://www.stuff.co.nz/southlandtimes/news/20032/Hearing-into-Kotuku-tragedy-held-in-city Hearing into Kotuku tragedy held in city 11/10/2007 and http://www.stuff.co.nz/southlandtimes/news/3908041/Exhibition-a-reflection-of-Ngai-Tahus-journey

\section{Unpublished material}

Te Rūnanga o Ngāi Tahu. Minutes of Te Papa Iwi Exhibition Steering Group Minutes 11 September 2006. Unpublished manuscript, 2006.

Te Papa. Concept development document. Unpublished manuscript, 2005.

Te Papa. Iwi exhibition Programme at Te Papa Tongarewa. Unpublished manuscript, 2011.

Te Papa. Iwi Relationship Strategy. Unpublished manuscript, n.d.

Te Papa. Mana Taonga. Unpublished manuscript, 1992.

Te Papa. Minutes of the Ngai Tahu Exhibition De-brief Meeting: Development \& Design Process. Unpublished manuscript, $2006 \mathrm{~b}$.

Te Papa. Mo Tatou: Development Design. Unpublished manuscript, 2006a.

Te Papa. Museum of New Zealand Te Papa Tongarewa Bicultural Policy. Unpublished manuscript, 1991.

Te Papa. The Mātauranga Māori Strategy: He Ara Whainga. Unpublished manuscript, 2004. Victoria University of Wellington. Human Ethics Policy. Wellington: Author, 2003. 


\section{Legislation}

Museum of New Zealand Te Papa Tongarewa Act 1992

Te Rūnanga of Ngai Tahu Act 1996

\section{Interviews}

Jane Davis, Dunedin: April 2011

Arapata Hakiwai, Wellington: September 2006

Vicki Ratana, Dunedin: April 2011

Puamiria Parata-Goodall, Dunedin, April 2011

Piri Sciascia, Wellington: April 2011 Mark

Solomon, Dunedin: April 2011

Megan Tamati-Quennell, Wellington, May 2011, October 2006

Carolyn Roberts-Thompson, Wellington, May 2011 